\title{
EVAPOTRANSPIRAÇÃO E COEFICIENTE DE CULTIVO DE MARACUJAZEIROS DETERMINADOS PELO MÉTODO DO BALANÇO DE RADIAÇÃO E LISIMETRIA DE PESAGEM HIDRÁULICA
}

TONNY JOSÉ ARAÚJO DA SILVA

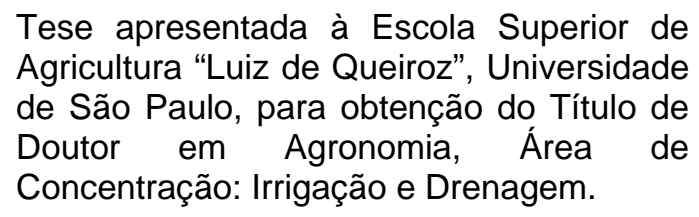

PIR A C I C A B A

Estado de São Paulo - Brasil

Março - 2005 


\title{
EVAPOTRANSPIRAÇÃO E COEFICIENTE DE CULTIVO DE MARACUJAZEIROS DETERMINADOS PELO MÉTODO DO BALANÇO DE RADIAÇÃO E LISIMETRIA DE PESAGEM HIDRÁULICA
}

\author{
TONNY JosÉ ARAÚJO DA SILVA \\ Engenheiro Agrônomo
}

Orientador: Prof $^{0}$ Dr. MARCOS VINíCIUS FOLEGATTI

\begin{abstract}
Tese apresentada à Escola Superior de Agricultura "Luiz de Queiroz", Universidade de São Paulo, para obtenção do Título de Doutor em Agronomia, Área de Concentração: Irrigação e Drenagem.
\end{abstract}

P I R A C I C A B A

Estado de São Paulo - Brasil

Março - 2005 
Dados Internacionais de Catalogação na Publicação (CIP) DIVISÃO DE BIBLIOTECA E DOCUMENTAÇÃO - ESALQ/USP

Silva, Tonny José Araújo da

Evapotranspiração e coeficiente de cultivo de maracujazeiros determinados pelo método do balanço de radiação e lisimetria de pesagem hidráulica / Tonny José Araújo da Silva. - - Piracicaba, 2005.

99 p. : il.

Tese (doutorado) - - Escola Superior de Agricultura Luiz de Queiroz, 2005.

Bibliografia.

1. Evapotranspiração 2. Fenologia 3. Irrigação 4. Lisímetro 5. Maracujá 6. Recursos hídricos I. Título

CDD 631.7

\section{"Permitida a cópia total ou parcial deste documento, desde que citada a fonte - O autor"}


A DEUS, pelo SOL.

AGRADEÇO

A minha esposa EDNA BONFIM-SILVA e meus filhos ELOIZE MARIANNY e TALLYS HENRIQUE, razão de minha vida.

DEDICO

A minha sogra EDITE BONFIM, uma exceção, verdadeiro exemplo de vida, autoridade em Administração Rural e Familiar. 


\section{AGRADECIMENTOS}

Ao Professor Dr. Marcos Vinícius Folegatti pela orientação, exemplo incontestável de dinamismo e competência, que mesmo ocupando cargo administrativo de Prefeito do Campus “Luiz de Queiroz”, dedicava-se a vida acadêmica sem medir esforços;

Aos amigos quase irmãos, Cláudio Ricardo e José Alves Júnior pelo convívio diário desde março de 2002 até fevereiro de 2005, mais de 8250 horas de perfeita harmonia, produção científica e descontração;

Ao coordenador do curso de Pós-Graduação em Irrigação e Drenagem, Chefe do Departamento de Engenharia Rural, Prof. Dr. José Antônio Frizzone, pela condição de trabalho oferecida;

Aos professores do Curso de Pós-Graduação em Irrigação e Drenagem: Sérgio Nascimento Duarte, Rubens Duarte Coelho, Tarlei Arriel Botrel, Iran José Oliveira da Silva e Décio Eugênio Cruciani.

Aos professores do Departamento de Ciências Exatas, Dr. Antonio Roberto Pereira e Dr. Nilson Augusto Villa Nova, pelo incentivo, admiração e ensinamentos;

Ao professor Dr José Júlio Vilar Rodrigues, pioneiro na lisimetria de pesagem hidráulica no Brasil, pela orientação de Mestrado, experiências que ajudaram na realização do trabalho de Doutorado;

Aos professores da Universidade Federal Rural de Pernambuco, Dr. Mário Rolim, Dr. Mário Lira Júnior e Dr Abelardo Montenegro, pelo incentivo na realização deste curso no Estado de São Paulo;

Aos professores Dr. Francisco Monteiro e Dr. Quirino Carmello, pela concessão da utilização de equipamentos do Laboratório de Nutrição de Plantas da ESALQ/USP;

Aos colegas Dr. Claudinei Fonseca Souza e Dr. Ênio Farias, pela amizade, apoio e sugestões. 
Ao professor Dr. Carlos Ruggiero da UNESP de Jaboticabal e a pesquisadora Dra. Laura Meletti do Instituto Agronômico (IAC), pelas informações sobre a cultura do maracujazeiro e doação das sementes utilizadas na pesquisa.

Aos colegas do Centro de Pesquisa e Desenvolvimento de Ecofisiologia e Biofísica do Instituto Agronômico (IAC), Dra. Regina Célia Mattos Pires, Dr. Flávio Bussmeyer Arruda, Dr. Emílio Sakai, Dr. Rinaldo Calheiros, Dr. Orivaldo Brunini, Dr. Rafael Ribeiro, Dr. Glauco Rolim, MSc.Grabriel Blain e Dr. José Ricardo Pezzopane, pelo convívio, amizade e confiança depositada;

As secretárias do Curso de Pós-Graduação em Irrigação e Drenagem, Davilmar Aparecida Domingues Collevatti e Vanda Macedo Zambelo, e as secretárias da Prefeitura do Campus “Luiz de Queiroz”, Beatriz Regina Novaes, Estela Maria Bigotto, Márcia Ganzella, Márcia Fecchio e Roseli Cappelletti exemplos de competência, paciência e desburocratização no serviço público;

Aos funcionários da Biblioteca Central - ESALQ/USP, Eliana e Silvia em particular, pelo grande auxílio na correção deste material;

Aos funcionários do Departamento de Engenharia Rural: Antônio, Lino, Gilmar, Osvaldo, Hélio, Sandra, Fernanda e César (In memoriam), por toda colaboração;

Aos colegas do curso em Pós-Graduação em Irrigação e Drenagem: Adriana Lúcia da Silva, Anamaria de Sousa Duarte, Ariovaldo Antônio Tadeu Lucas, Célia Regina Ferrari Faganello, Edvaldo Casarini, Francisco Edinaldo Pinto Mousinho, Guilherme Busi de Carvalho, João Célio de Araújo, Jocelito Saccol de Sá, Leandro Fellet Lourenço, Luis Gonzaga Figueredo Júnior, Márcio Aurélio Lins dos Santos, Marco Antônio Jacomazzi, Marconi Batista Teixeira, Marcos Emanuel da Costa Veloso, Miguel Angel Isaac Toledo del Pino, Miguel Ferreira Neto, Nildo da Silva Dias, Patrícia Angélica Alves Marques, René Porfírio Camponez do Brasil, Ruben Alcides Franco Ibars, Roberta Alessandra Bruschi Gloaguen, Roberto Terumi Atarassi, Rodrigo Alessandro de Lima Corrêa, Rodrigo Otávio Rodrigues de Melo Souza e Tales Miler Soares.

Aos estudantes do Curso de Graduação em Engenharia Agronômica da ESALQ/USP, estagiários do Grupo de Práticas em Irrigação e Drenagem (GPID), pela colaboração e condução do experimento; 
A Escola Superior de Agricultura "Luiz de Queiroz", por toda sua estrutura que me foi concedida para o desenvolvimento desta pesquisa.

À Coordenação de Aperfeiçoamento de Pessoal de Nível Superior (CAPES), pela concessão da bolsa de estudo;

À Fundação de Amparo à Pesquisa do Estado de São Paulo (FAPESP), pelo financiamento do projeto de pesquisa;

Enfim, para todos aqueles que de alguma maneira colaboraram para realização deste trabalho. 


\section{SUMÁRIO}

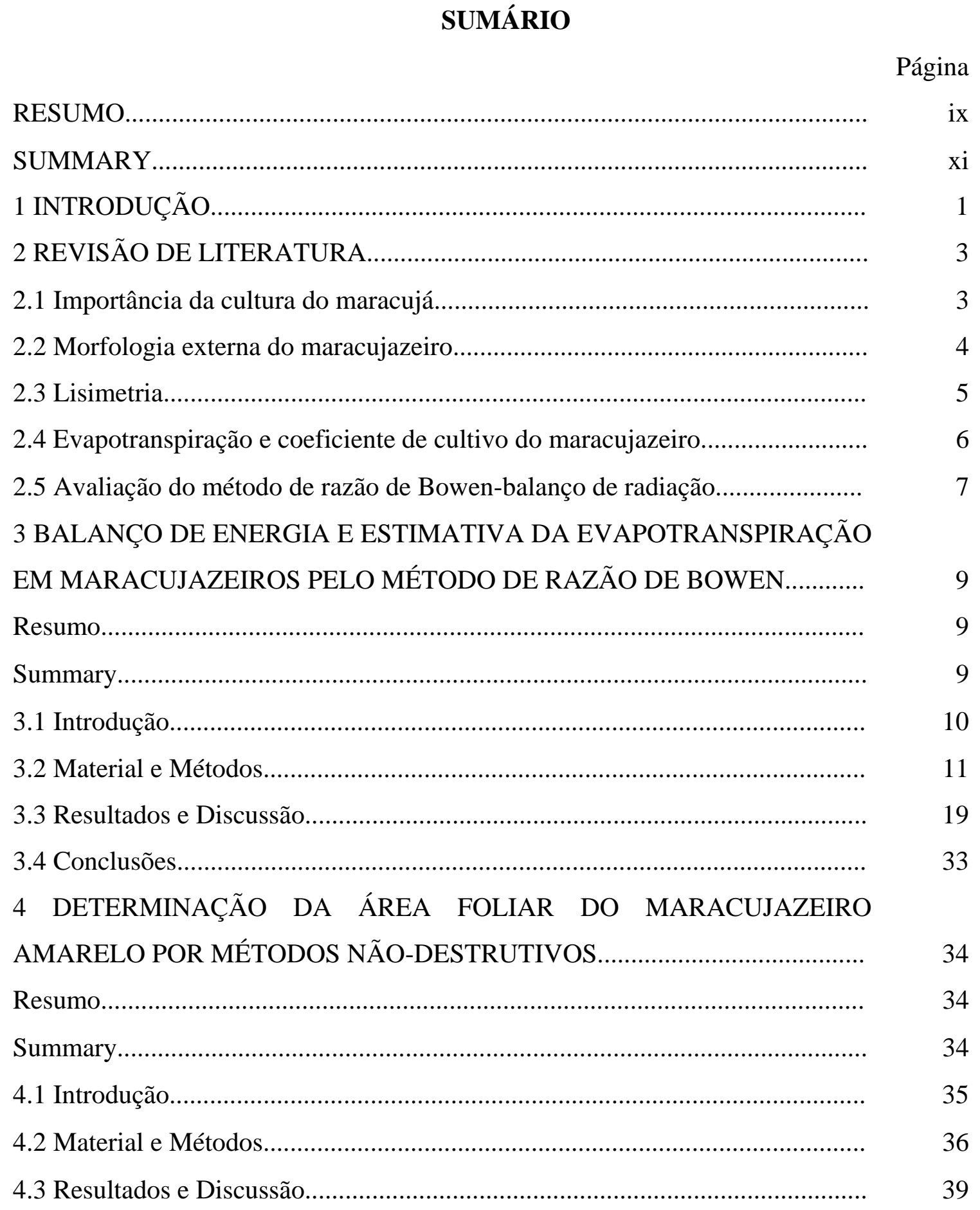




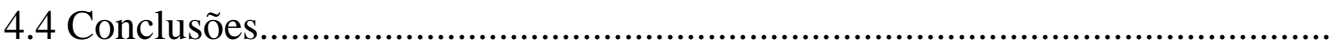

5 CONSTRUÇÃO E CALIBRAÇÃO DE LISÍMETROS DE PESAGEM COM CÉLULAS DE CARGA HIDRÁULICA.......................................................... 50

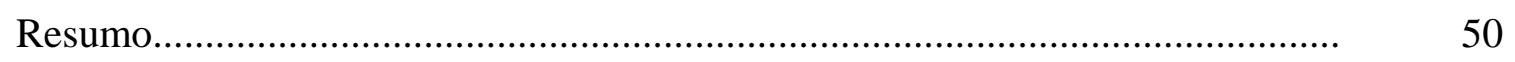

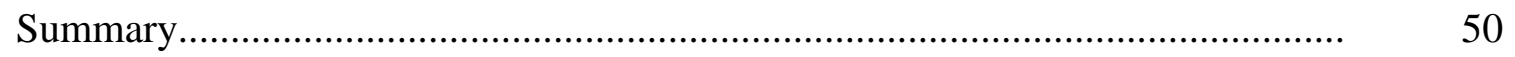

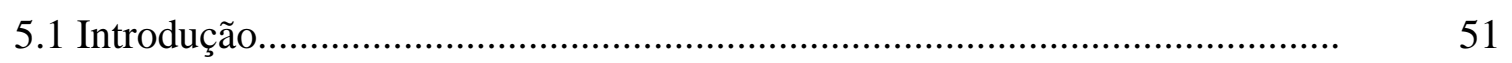

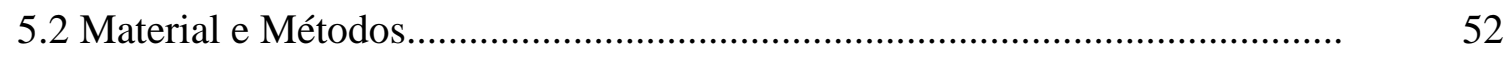

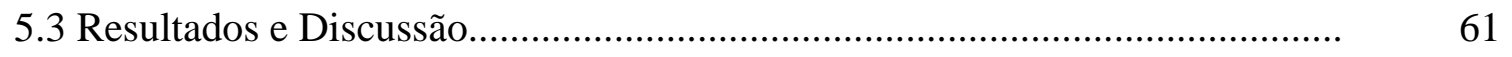

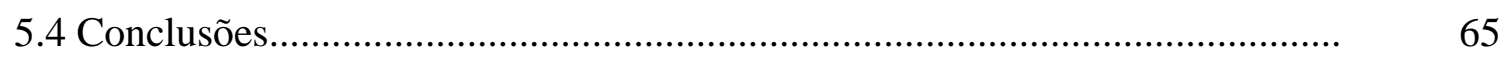

6 DETERMINAÇÃO DA EVAPOTRANSPIRAÇÃO DE

MARACUJAZEIROS UTILIZANDO LISÍMETRO DE PESAGEM

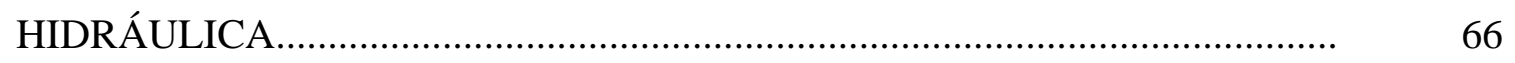

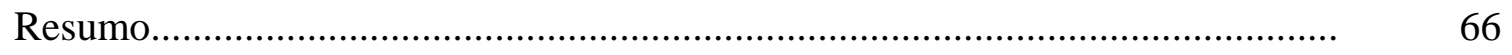

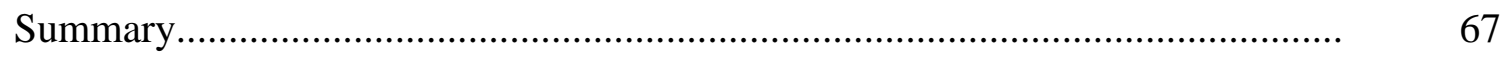

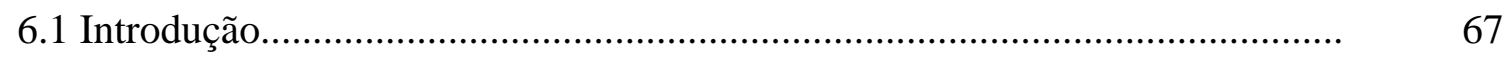

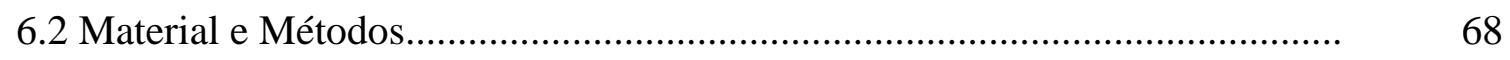

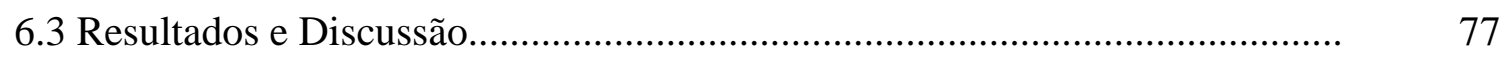

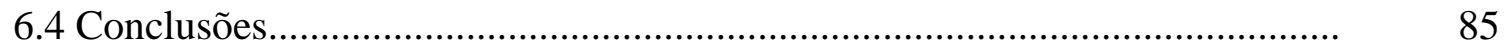

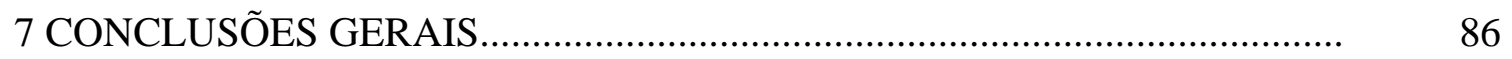

REFERÊNCIAS BIBLIOGRÁFICAS.......................................................... 87

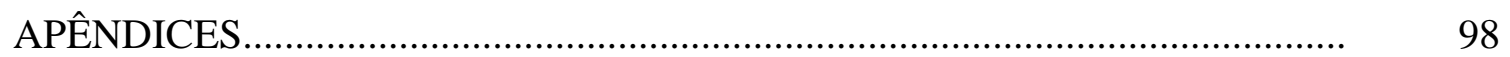




\title{
EVAPOTRANSPIRAÇÃO E COEFICIENTE DE CULTIVO DE MARACUJAZEIROS DETERMINADOS PELO MÉTODO DO BALANÇO DE RADIAÇÃO E LISIMETRIA DE PESAGEM HIDRÁULICA
}

\author{
Autor: TONNY JOSÉ ARAÚJO DA SILVA \\ Orientador: Prof ${ }^{\mathfrak{o}}$ Dr. MARCOS VINÍCIUS FOLEGATTI
}

\section{RESUMO}

Este trabalho foi realizado na área experimental de irrigação, na Fazenda Areão do Departamento de Engenharia Rural da Escola Superior de Agricultura “Luiz de Queiroz” ESALQ/USP (Piracicaba-SP). Transplantaram-se mudas de maracujazeiro amarelo (Passiflora edulis Sims f. flavicarpa Deg), cv. IAC 275, com 83 dias após a germinação, para duas parcelas experimentais com espaldeiras na direção Norte-Sul e Leste-Oeste. O método da razão de Bowen foi utilizado na determinação dos fluxos de calor sensível e latente. Foram coletados dados de saldo de radiação, fluxo de calor no solo, gradientes de temperatura e pressão de vapor com objetivo de avaliar a partição da energia disponível e a evapotranspiração em cultivo de maracujazeiros. Em teste de laboratório e campo, avaliaou-se o desempenho das células de carga hidráulica, através de calibrações simultâneas em comparação as células eletrônicas, e por fim, verificou-se o funcionamento de um transdutor de pressão eletrônico acoplado às células para automação dos dados. Na determinação do consumo de água pelas plantas, utilizaram-se quatro lisímetros de pesagem hidráulica, iguais, sendo dois por parcela. Nos lisímetros de pesagem hidráulica o consumo medido, em litros planta ${ }^{-1} \mathrm{dia}^{-1}$, foi ajustado de acordo com a área foliar da planta instalada, para hipoteticamente uniformizar o desenvolvimento vegetativo, permitindo 
assim, compará-las entre si. O saldo de radiação não foi influenciado pelo sistema de plantio, sendo equivalente a $60 \%$ da radiação global. O componente de maior contribuição no balanço de radiação foi o calor latente de evaporação. O fluxo de calor sensível teve valores mais significativos imediatamente após as chuvas ou irrigações. A utilização do modelo de análise e exclusão de intervalos em que o método de Razão de Bowen falha, melhora a estimativa da evapotranspiração. $\mathrm{O}$ arranjo das células de carga em forma de triangulo eqüilátero promoveu boa estabilidade e distribuição equilibrada de forças. $\mathrm{O}$ estabelecimento do volume ideal de fluído proporcionou calibrações lineares e consequentemente, melhor desempenho dos lisímetros. As correlações entre os valores de variação de massa observadas no piezômetro, célula eletrônica e transdutor de pressão apresentaram relação linear com alto coeficiente de determinação. A lâmina acumulada até o 450 DAP representativa para a parcela Norte-Sul foi de $1171 \mathrm{~mm}$, superior a $1083 \mathrm{~mm}$ acumulado na parcela Leste-Oeste. Os valores extremos de consumo foram em média $5 \mathrm{~L}$ planta $^{-1}$ dia $^{-1}$, durante o outono e inverno, e $8 \mathrm{~L} \mathrm{planta}^{-1} \mathrm{dia}^{-1}$, no Verão. Não houve diferença significativa para a ETc das parcelas nos meses de menor disponibilidade energética. Foram determinados coeficientes de cultivo de 0,6 para a fase de crescimento vegetativo apical, 0,9 para a fase de crescimento vegetativo lateral, 1,2 para a fase de floração e frutificação, 1,0 para a fase de maturação dos frutos, 0,8 para a fase pósmaturação dos frutos. 


\title{
EVAPOTRANSPIRATION OF PASSIONFRUIT AND CROP COEFFICIENT DETERMINED BY ENERGY BALANCE AND LYSIMETER HYDRAULIC WEIGHING
}

\author{
Author: TONNY JOSÉ ARAÚJO DA SILVA \\ Adviser: Prof $^{0}$ Dr. MARCOS VINÍCIUS FOLEGATTI.
}

\section{SUMMARY}

This work was carried out at the experimental irrigation farm of the Engineering Department - College of Agriculture Luiz de Queiroz - ESALQ/USP in Piracicaba, São Paulo, State. The 83-day-old passiflora seedlings (Passiflora edulis Sims f. flavicarpa Deg cv. IAC 275) were transplanted to experimental units with rows planted based on NorthSouth and East-West directions. The Bowen ratio method was used to determine both sensible heat and latent heat fluxes. It was collected micrometeorological data from net radiation, soil flux heat, temperature and vapor pressure gradient with the aim to evaluate the energy available partition and evapotranspiration of trees planted under two row directions. The performance of a hydraulic load cells and a pressure transductor were evaluated by calibration of electronic load cells in laboratory and field conditions. In order to determine the evapotranspiration, it was used four similar hydraulic weighing lysimeters, being two in each direction of plant row. The daily evapotranspiration in liters per plant was adjusted to the leaf area present in each lysimeter, to hypothetically uniform the vegetative development and compare the values themselves. The net radiation was not influenced by row directions, and it was $60 \%$ of global radiation. The latent heat of evaporation was the major role on energy balance and the significant values happened immediately after a rainfall or irrigation. The use of intervals and exclusion analyzes model, when the Bowen ratio fails, improve the estimative of evapotranspiration. The 
triangular design of load cells promoted a good stability and distribution of forces. The establishment of an ideal fluid volume leaded a liner calibrations and better performances. Relationships between mass variation read in piezometer, electronic load cells and pressure transductor showed linear relation and high determination coefficient. The accumulative depth at 450 DAP for North-South unit was $1171 \mathrm{~mm}$ higher than $1083 \mathrm{~mm}$ for East-West. The average of extremes values for evapotranspiration was $5 \mathrm{~L}_{\text {plant }}{ }^{-1}$ day $^{-1}$ for autumn and winter and $8 \mathrm{~L}_{\text {plant }}{ }^{-1}$ day $^{-1}$ for summer period. No significant differences were found for ETc for units in months of lower energetic availability. The values for crop coefficient were 0.6 for apex vegetative growth, 0.9 for lateral vegetative growth, 1.2 for flowering and fruit development, 1.0 for fruit maturation and 0.8 for post-maturation period. 


\section{INTRODUÇÃO}

Com ambiente favorável para o desenvolvimento de muitas espécies vegetais, a produção agroalimentar no Brasil constitui um dos mais promissores setores da economia Nacional. Neste aspecto os frutos tropicais destacam-se por serem alimentos mais saudáveis, calóricos, ricos em vitaminas e sais minerais, e cada vez mais presentes na dieta alimentar das populações.

O maracujazeiro amarelo (Passiflora edulis Sins var. flavicarpa Deg.) é a principal espécie da família Passifloraceae, sendo o Brasil, ponto de origem de um grande número de espécies em função das condições excepcionais de clima ideal para o seu desenvolvimento. A temperatura, radiação, fotoperíodo, precipitação e ventos, promovem

respostas fisiológicas diferentes, sendo estes, alguns parâmetros meteorológicos que interferem diretamente na sua produção. Sabe-se que o maracujazeiro amarelo é uma planta de dias longos, necessitando de fotoperíodo maior que 11 horas para florescer. Assim, no Brasil, onde a luminosidade é intensa e a temperatura permanece elevada durante todo o ano, registram-se as maiores produtividades $\left(40 \mathrm{tha}^{-1}\right)$.

O cultivo do maracujazeiro apresenta um prolongamento de safra que pode variar de oito meses para a região Sudeste, dez meses no Nordeste e até doze meses na região Norte, garantindo dessa maneira um fluxo de renda mensal e contínuo, contribuindo para elevar o padrão de vida de pequenos produtores rurais, diferente de outros cultivos onde a remuneração dá-se apenas no final do ciclo da cultura, no período de colheita. Este é o principal aspecto que cada vez mais atrai novos produtores, porém muitos abandonam seu cultivo rapidamente por falta de informações tecnológicas de produção.

Dentre as técnicas inerentes a produção do maracujá, a irrigação tem a função de manter o teor de água ideal no solo, proporcionando maiores produtividades, melhor qualidade de frutos, melhores preços de mercado e prolongamento de safra. 
A utilização da prática da irrigação no maracujazeiro requer estudos das propriedades do solo, da área de atuação e profundidade efetiva alcançada pelo sistema radicular no solo, condições de clima da região e conhecimento das respostas fisiológicas promovida por todos estes fatores.

Apresentando a cultura do maracujazeiro grande potencial no agronegócio do Estado de São Paulo, tanto no mercado interno como no externo, aliado ao fato da constante necessidade de desenvolver tecnologias para maximizar o aproveitamento de recursos hídricos, este projeto tem como objetivos avaliar a evapotranspiração do maracujazeiro amarelo (Passiflora edulis Sins var. flavicarpa Deg.) através de lisímetros de pesagem hidráulica, método do balanço de radiação baseado na razão de Bowen, e estabelecer coeficientes de cultivos $(K c)$ para os diferentes estádios fenológicos da cultura. 


\section{REVISÃO DE LITERATURA}

\subsection{Importância da cultura do maracujá}

O Brasil é o maior produtor mundial de maracujá (Passiflora edulis Sims. var. flavicarpa Deg.) e emprega no campo entre 112 a 272 dias homem ha $^{-1}$ ano $^{-1}$ (Pires \& São José, 1994; AGRIANUAL, 2002), uma vez que a geração de emprego na industria e na comercialização também ocorre, pois é o terceiro suco mais produzido no Brasil (Aguiar \& Santos, 2001), além de ser considerada uma cultura adequada para pequenas propriedades (AGRIANUAL, 1999).

O Planalto Ocidental Paulista foi uma região colonizada no período da expansão da cultura cafeeira no Estado de São Paulo. Miranda \& Bemelmans (1995), afirmaram que naquela época, muitas pequenas propriedades, outrora unicamente cafeicultoras, já procuravam alternativas para diversificar sua produção, com o objetivo de maximizar seus rendimentos e minimizar seus riscos, inclusive oferecendo trabalho no meio urbano.

A cultura do maracujá azedo ou amarelo, que vem se expandindo já há duas décadas, ganhou um impulso adicional, tanto pela crise cafeeira quanto por ser estimulada pelos órgãos de extensão rural governamentais (Coordenadoria de Assistência Técnica Integral/CATI).

Apesar da sua relevância, houve pouco avanço na produção dessa cultura entre 1990 e 2000. A área plantada cresceu apenas 33,4\%, mas com decréscimo de 20,8\% na produtividade, que passou de 12,5 $\mathrm{t} \mathrm{ha}^{-1}$ em 1990 para 9,9 $\mathrm{t} \mathrm{ha}^{-1}$ em 2000 (IBGE, 2002).

O potencial produtivo do maracujazeiro, entretanto, é bem maior, podendo alcançar até 65,21 t ha-1 ${ }^{-1}$ com a utilização de genótipos superiores, como o híbrido IAC-3 (Meletti et al., 2000). 
No Brasil, diversos trabalhos revelaram resultados significativos do adensamento de até 5.000 plantas ha-1 $^{-1}$ correspondendo ao espaçamento de 2,0 x 1,0 m (Pace \& Araújo, 1981), atingindo produtividade de $33,1 \mathrm{t} \mathrm{ha}^{-1}$ na primeira safra.

Andrade et al. (1994) constataram que com o espaçamento de 3,0 x 1,5 m produziu na safrinha $14,5 \mathrm{t} \mathrm{ha}^{-1}, 219 \%$ a mais que o maior espaçamento de 3,0 x 6,0 m.

São José (1998) recomenda plantio com espaçamento de 3,5 x 1,75 m, que apresenta potencial produtivo de $20 \mathrm{t} \mathrm{ha}^{-1}$. Porém, alguns trabalhos não apresentaram efeito significativo, como os de Cereda \& Vasconcelos (1991), cuja produtividade média foi de 26,4 t ha ${ }^{-1}$ e densidade variando de 833 a 3.333 plantas ha ${ }^{-1}$, e Manica et al. (1989), com produtividade média de 12,8 $\mathrm{t} \mathrm{ha}^{-1}$, em densidade variando de 695 a 2.000 plantas ha ${ }^{-1}$. Além disso, a maior produtividade obtida com o adensamento pode não proporcionar maior retorno econômico (Kits et al., 1996).

\subsection{Morfologia externa do maracujazeiro}

O maracujazeiro é uma planta trepadeira, robusta, podendo atingir 5 a $10 \mathrm{~m}$ de comprimento, portanto, é de fundamental importância a utilização de um sistema de condução (espaldeira), para seu crescimento (Ruggiero et al. ,1996).

Em culturas trepadeiras onde se torna necessário conduzi-la sobre um suporte fixo, as determinações lisimétricas por pesagem (lisímetro de pesagem), consideradas mais precisas, não são aplicadas na maioria dos casos, devido à dificuldade de integrar os suportes no sistema de medida dos lisímetros. Outro problema refere-se à ação do vento sobre os ramos da planta promovendo variações de peso e levando a erros nas determinações de evapotranspiração (ET).

A adoção de outras ferramentas como lisímetros de nível freático constante, de drenagem, balanço hídrico do solo e balanço de energia são alternativas utilizadas por muitos autores nestas condições de cultivo (Oliver \& Sene, 1992; Saad, 1998; Alencar, 2000 e Correa, 2004). 


\subsection{Lisimetria}

A evapotranspiração da cultura pode ser determinada por métodos diretos ou indiretos. Os métodos diretos baseiam-se no balanço hídrico em volume de solo conhecido e os indiretos em parâmetros climáticos. Dentre os métodos de medida direta, os lisímetros se destacam por oferecer o maior nível de precisão para a determinação da evapotranspiração (Pereira et al., 1997).

Silva et al. (1999), comparando lisímetros de drenagem, lençol freático constante e pesagem, concluíram que lisímetros de pesagem apresentam-se mais precisos e consistentes na determinação da evapotranspiração.

Aboukhaled (1982) classificou os lisímetros quanto à forma de obtenção de dados em pesagem e não pesagem, atribuindo maior precisão ao primeiro tipo. Quanto aos de pesagem, esses foram classificados em quatro tipos: sistema mecânico; mecânico com célula de carga eletrônica; célula de carga eletrônica e célula de carga hidráulica.

Os lisímetros de pesagem com células de carga hidráulica são equipamentos que apresentam qualidade e precisão dos resultados, além de baixo custo e facilidade na construção e operacionalização, com resolução de até 0,025 mm por leitura de evapotranspiração de referência (ETo) (Freitas, 1994).

Os lisímetros de pesagem hidráulica foram descritos por Hanks \& Shawcroft (1965), Tanner (1967), Dylla \& Cox (1973), e Mcfarland et al. (1983). No Brasil, o primeiro equipamento deste tipo foi construído e descrito por Rodrigues (1987), para estudos de evapotranspiração de grama (ETo), na cidade de Parnamirim, Pernambuco. Posteriormente no Brasil, outros equipamentos deste tipo foram construídos e avaliados (Freitas, 1994; Costa, 1999; Silva, 2003). Diferentes modelos e adaptações têm sido feitas para estes equipamentos ao longo dos anos. A principal vantagem destes equipamentos está relacionada à boa precisão em escala diária e o baixo custo de construção comparado aos construídos com células de carga eletrônica, por exemplo.

De acordo com Silva (2003), alguns critérios devem ser considerados: (1) as células de carga hidráulica devem ser confeccionadas com materiais que não permitam fadiga, (2) o volume de fluido nas células de carga deve ser adequado para que a área de 
contato com a base do lisímetro permaneça constante e (3) o efeito da temperatura é atenuado quando as leituras são realizadas sempre na mesma hora do dia.

\subsection{Evapotranspiração e coeficiente de cultivo do maracujazeiro}

Alencar (2000) afirmou até então, não existir na literatura informações sobre a evapotranspiração e coeficiente de cultivo para o maracujazeiro. Contudo, os valores de Kc obtidos em seu trabalho, entre 0,37 e 1,10 e valores máximos de evapotranspiração da cultura $(E T c)$ na ordem de 4,68mm d $\mathrm{d}^{-1}$, em 4 lisímetros de drenagem cultivado com maracujazeiro instalados no centro de uma área de 0,4 ha, em Piracicaba-SP, foram limitados à valores médios referentes à sub-períodos de 15 dias, por causa de restrição promovida pelo lisímetro de drenagem.

Costa (2000) divulgou valor fixo de $K c$ de 0,8 ao longo do ano, para plantas adultas de maracujazeiro ocupando área útil de $12 \mathrm{~m}^{2}$.

Silva (2002) avaliando a demanda hídrica do maracujazeiro amarelo com lisímetros de lençol freático constante, em Botucatu_SP, encontrou valores de Kc entre 0,42 e 1,12 .

Corrêa (2004) determinou para 6 estádios de desenvolvimento para o maracujazeiro amarelo, em Piracicaba-SP, valores de $K c$ de 0,3 para a fase de desenvolvimento inicial, 0,4 para a fase de crescimento vegetativo apical, 0,5 para a fase de crescimento vegetativo lateral, 0,9 para a fase de florescimento, frutificação e maturação dos frutos, 0,8 para a fase de repouso vegetativo e 0,7 para início do florescimento e frutificação do segundo ciclo de produção. Nesta pesquisa, o autor utilizou lisímetro de drenagem e considerou a evapotranspiração das plantas invasoras das entrelinhas, em cultivo espaçado de $4 \times 3,5 \mathrm{~m}$. 


\subsection{Avaliação do método de Razão de Bowen-Balanço de Radiação (RBBR)}

O fracionamento da energia disponível entre o calor sensível e latente pode ser usualmente obtido pelo método Razão de Bowen-Balanço de Radiação ( $R B B R$ ), baseado nas relações de transferência de massa e energia no perfil de fluxo, para estimativa da evapotranspiração sobre uma superfície vegetada ou solo nú. Entretanto, neste método a exatidão dos valores calculados de fluxos de calor sensível e latente, depende da exatidão da razão de Bowen ( $\beta$ ), o qual depende por sua vez da exatidão das medidas. Conseqüentemente, há necessidade de analisar os erros associados a este método para entender como eles podem afetar os resultados e para determinar expressões simples para parametrização quando o método $R B B R$ fornece fracionamento consistente do fluxo superficial.

Os erros introduzidos pelo método $R B B R$ na determinação dos valores de fluxos de energia têm sido já avaliados por vários autores (Fuchs \& Tanner, 1970; Sinclair et al., 1975; Angus \& Watts, 1984; Bertela, 1989).

Em muitos outros trabalhos em que o método $R B B R$ é utilizado, para evitar vários erros na estimativa dos fluxos, os dados inerentes ao erro instrumental do sistema Razão de Bowen são excluídos. Por exemplo, medidas de gradiente menor que a resolução dos sensores. Para casos em que os valores de $\beta$ estão próximo de -1 , alguns autores elimina os valores de $\beta$ abaixo de -0,75, ou valores entre $-1,3<\beta<-0,7$ (Ortega-Farias et al., 1996; Unland et al., 1996). Mas esse intervalo deve depender da exatidão da medida dos sensores utilizados.

Uma vez que há uma grande diferença nos processos de transferência de energia entre o dia e a noite devido à disponibilidade de energia e estabilidade atmosférica, alguns autores consideram apenas reais intervalos dados de medidas de gradientes ou apenas as amostragens calculadas sobre o período do dia, excluindo dados falhos correspondente a dias chuvosos ou outros problemas de medida (Ashktorab et al., 1989; Heilman \& Brittin, 1989; Cellier et al., 1996; Unland et al., 1996). Entretanto, os subconjuntos dos dados a ser excluídos podem depender das características climáticas do local da amostragem. Geralmente, nos lugares com climas áridos e semiáridos e com umidade do solo muito 
limitada, os gradientes da pressão de vapor durante o dia serão menores e os gradientes da temperatura maiores do que aqueles de áreas úmidas (Miller, 1977).

Um outro problema ocorre quando por curtos períodos, menores do que uma hora, nenhum dado confiável está disponível; então, os valores de fluxos da energia em falta devem ser interpolados aos valores precedentes e subseqüentes, com as incertezas subseqüentes introduzidas nos valores diários do evapotranspiração. As situações em que o $R B B R$ falha ou causa resultados inconsistentes devem ser analisados (Blad \& Rosenberg, 1974; Ohmura, 1982; Angus \& Watt, 1984; Bertela, 1989), assim como, a relação entre os erros de medidas e os erros de fluxo de energia (Fuchs \& Tanner, 1970; Blad \& Rosenberg, 1974; Sinclair et al., 1975). Entretanto, um procedimento claro para rejeitar os fluxos computados dependendo dos dados coletados nunca foi proposto.

Uma vez que não há nenhum conjunto de critérios práticos e geral para selecionar entre valores reais e não reais de $\beta$, exceto sobre superfícies saturadas (Philip, 1987; Andreas, 1989; Andreas \& Cash, 1996).

Perez et al. (1999), propõem uma metodologia que determina os valores confiáveis de $\beta$ e de fluxos de calor latente $(\lambda E)$ e sensível $(H)$ baseado nos limites de resolução dos sensores e gradientes de pressão de vapor, fornecendo uma resposta prática e clara ao problema da avaliação de quando o método de $R B B R$ fornece valores falhos.

As proposições na utilização do método $R B B R$ são que os coeficientes de transferência turbulenta de calor e vapor sejam idênticos, caso válido em condições neutras, e ao contrário nas condições de estabilidade. Para minimizar este efeito, deve-se ter uma extensa superfície homogênea de contorno, para que a distância em relação à direção predominante do vento esteja na ordem de 1:100, comparada a maior altura de medida pelos sensores (Heilman \& Brittin, 1989; Monteith \& Unsworth, 1990; Horst \& Weil, 1992).

Herbst (1995) citou vários estudos em que a relação entre 47:1 e 12:1 foram adequadas para superfícies rugosas como florestas, mas a técnica não é recomendada para superfícies heterogêneas e declivosas (Brutsaert, 1982). 


\section{BALANÇO DE ENERGIA E ESTIMATIVA DA EVAPOTRANSPIRAÇÃO EM MARACUJAZEIROS PELO MÉTODO DE RAZÃO DE BOWEN}

\section{Resumo}

Este trabalho foi realizado na área experimental de irrigação, na Fazenda Areão do Departamento de Engenharia Rural da Escola Superior de Agricultura “Luiz de Queiroz” ESALQ/USP (Piracicaba-SP). Foram coletados dados de saldo de radiação, fluxo de calor no solo, gradientes de temperatura e pressão de vapor do ar com objetivo de avaliar a partição da energia disponível e a evapotranspiração em cultivo de maracujazeiros em dois sistemas de plantio (Norte-Sul e Leste-Oeste). O método da razão de Bowen foi utilizado na determinação dos fluxos de calor sensível e latente. O saldo de radiação não foi influenciado pelo sistema de plantio, sendo equivalente a $60 \%$ da radiação global. O componente de maior contribuição no balanço de radiação foi o calor latente de evaporação. O fluxo de calor sensível teve valores mais significativos apenas imediatamente após as chuvas ou irrigações. A utilização do modelo de análise e exclusão de intervalos em que o método de Razão de Bowen falha, melhora a estimativa da evapotranspiração.

\section{Summary}

This work was carried out at the experimental irrigation farm of the Engineering Department - College of Agriculture Luiz de Queiroz - ESALQ/USP in Piracicaba, São Paulo, State. Were collected micrometeorological data from net radiation, soil flux heat, temperature and vapor pressure gradient with the aim to evaluate the partition of energy available and evapotranspiration of passionfruit crop planted under two row directions (North-South and East-West). The Bowen ratio method was used to determine both sensible and latent fluxes. The net radiation was not influenced by row directions, being 
$60 \%$ of global radiation. The latent heat of evaporation played the major role on energy balance and values more significantly happened immediately after a rainfall or irrigation. The estimat of evapotranspiration has improved when the interval that Bowen ratio fails were excluded.

\subsection{Introdução}

O maracujazeiro amarelo (Passiflora edulis Sins var. flavicarpa Deg) é a principal espécie de importância econômica da família Passifloraceae. O Estado de São Paulo aparece com a maior expansão de área cultivada, onde a cultura é bem adaptada. Trata-se de uma atividade bastante atrativa para pequenos produtores, uma vez que oferece retorno econômico rápido com receitas distribuídas quase o ano inteiro (Souza \& Melleti, 1997).

A irrigação do maracujazeiro tem a função de manter um teor de água adequado no solo, proporcionando maiores produtividades, melhor qualidade de frutos e melhores preços de mercado. Para o manejo da água, o conhecimento da evapotranspiração e de sua estimativa, torna-se necessário para a irrigação racional.

A temperatura, radiação, fotoperíodo, precipitação e vento são alguns elementos meteorológicos que condicionam a evapotranspiração (Pereira, 2002). Constata-se ainda a existência de poucos estudos sobre parâmetros micrometeorológicos que atuam na evapotranspiração da cultura do maracujazeiro. O processo de evapotranspiração é governado pela troca de energia na superfície, limitada pela energia disponível. É possível estimar-se o fluxo de calor latente de evaporação, através do princípio da conservação de energia (Teixeira, 2001), e estimar-se a evapotranspiração através da equação simplificada do balanço de energia, constituída pelo saldo de radiação $(R n)$, pelo fluxo de calor latente $(\lambda E)$, calor sensível $(H)$ e pelo fluxo de calor no solo $(G)$. A solução da equação é obtida por medidas de $R n$ e $G$ e de estimativa de $\lambda E$ e $H$ utilizando o método da Razão de Bowen (Bowen, 1926), que considera a relação $\beta=H / \lambda E$. Trambouze et al., (1998) utilizando o método do balanço de energia na cultura da videira, concluíram que a vantagem na estimativa da evapotranspiração consiste no fato do método poder ser utilizado para períodos curtos. 
Em outros trabalhos em que o método de Razão de Bowen-Balanço de Radiação $(R B B R)$ foi utilizado, para evitar erros na estimativa dos fluxos, os dados inerentes ao erro de instrumental micrometeorológico do sistema Razão de Bowen, são excluídos. Um exemplo é o caso dos intervalos de medidas de gradiente de $H, G$ e vapor serem menores do que as resoluções dos sensores. Para casos em que os valores de $\beta$ estão próximo de -1 , alguns autores eliminam os valores de $\beta$ abaixo de $-0,75$, ou valores entre $-1,3<\beta<-0,7$ (Ortega-Farias et al., 1996; Unland et al., 1996).

Perez et al. (1999), propõem uma metodologia que determina os valores confiáveis de $\beta$ e de fluxos de calor latente $(\lambda E)$ e sensível $(H)$ baseado nos limites de resolução dos sensores e gradientes de pressão de vapor, fornecendo uma resposta prática e clara ao problema da avaliação de quando o método de $R B B R$ fornece valores falhos.

O objetivo do presente estudo foi (i) quantificar a partição da energia solar disponível e a evapotranspiração de maracujazeiros em duas áreas com diferentes orientações de plantio (linhas de cultivo Norte-Sul e Leste-Oeste), empregando-se o método de Razão de Bowen e (ii) avaliar um método de identificação e exclusão de dados inconsistentes de Razão de Bowen.

\subsection{Material e Métodos}

\subsubsection{Localização e descrição do sistema de cultivo}

O experimento foi conduzido na área experimental de irrigação, na Fazenda Areão do Departamento de Engenharia Rural da Escola Superior de Agricultura "Luiz de Queiroz” - ESALQ/USP (Piracicaba-SP). O local, possui latitude $22^{\circ}$ 43'33’'S, longitude 47 38’0’’O e altitude de $576 \mathrm{~m}$. O clima é do tipo Cwa, segundo a classificação climática de Köeppen, sendo, subtropical úmido com estiagem no inverno, temperatura e precipitação média anual de $21,1^{\circ} \mathrm{C}$ e $1250 \mathrm{~mm}$, respectivamente. O solo foi classificado como Nitossolo (Embrapa, 1999). O transplantio de mudas de maracujazeiro (Passiflora edulis) da cv IAC 275 foi realizado em 25/10/2003, aos 83 dias após a germinação. O sistema de condução foi do tipo espaldeira vertical com espaçamento entre mourões, e entre plantas, de $4 \times 4 \mathrm{~m}$, com um único fio de arame AWG12 a 2 m acima da superfície do terreno. Toda a área 
(aproximadamente 0,5 ha) foi irrigada por microaspersão, procurando manter o potencial de água no solo acima do limite de $-20,0 \mathrm{kPa}$, monitorado por tensiômetro a profundidade de 0,20 m. O volume total de água aplicado foi determinado pela média das leituras de 2 lisímetros de pesagem hidráulica, estabelecendo o tempo de irrigação de acordo com a vazão do microaspersor $\left(40 \mathrm{~L} \mathrm{~h}^{-1}\right)$.

\subsubsection{Cálculo da partição de energia e evapotranspiração}

Durante o estudo foram realizadas medidas do saldo de radiação $(R n)$, fluxo de calor no solo $(G)$ e dos gradientes de temperatura do ar e de pressão de vapor, em dois níveis acima do dossel da cultura $(0,20 \mathrm{~m}$ e 1,2 m), com psicrômetros de termopar aspirados.

Com medidas de $R n, G$, e dos gradientes de temperaturas $(\Delta T)$ obtidos pelos psicrômetros, foram calculados os fluxos $\lambda E$ (Equação 1) e $H$ (Equação 2) empregando-se a Equação 3 (Tanner et al., 1987; Kustas et al., 1996) segundo a razão de Bowen ( Equação 4) e a equação da conservação de energia (Equação 5).

$$
\lambda E=\frac{R n-G}{1+\beta}
$$

$H=\left[\frac{\beta}{(1+\beta)}\right](R n-G)$

$\beta=\gamma \frac{\Delta T}{\lambda E}$

$\beta=\frac{H}{\lambda E}$ 
$R n=G+H+\lambda E$

em que, $\beta$ é a razão de Bowen, $H$ e $\lambda E$ são os fluxos de calor sensível e latente, respectivamente, $R n$ o saldo de radiação e $G$ o fluxo de calor no solo.

\subsubsection{Instalação dos sistemas de balanço de radiação e medições micrometeorológicas}

Para calcular a razão de Bowen ( $\beta$ ) pelo método do balanço de energia são necessárias medidas de gradiente de temperatura $(\Delta T)$ e pressão de vapor $\left(\Delta e_{a}\right)$. O sistema de razão de Bowen utilizado neste experimento foi adaptado do equipamento comercialmente produzido pela Campbell Scientific Inc. As razões pelas quais modificouse a configuração original do equipamento comercialmente produzido, foi devido aos problemas de funcionamento do higrômetro de ponto de orvalho (modelo Dew 10 - General Eastern). Este sensor é baseado na reflexão de uma fonte luminosa medida por um sensor óptico. Na parte traseira do espelho há uma pequena junção de diferentes metais que quando fornecido uma determinada corrente elétrica promove seu resfriamento. $\mathrm{O}$ ar aspirado por meio de uma bomba, contendo uma determinada concentração de vapor, ao entrar em contato com o espelho condensa umidade, modificando seu coeficiente de reflexão. Esta alteração na reflexão é imediatamente identificada pelo sensor óptico, que informa ao sistema de aquisição de dados, para o armazenamento daquele valor de temperatura. De posse desta temperatura, que corresponde à temperatura de ponto de orvalho $\left(T_{d}\right)$, e aplicando-se a equação de Tetens para determinar a pressão de saturação de vapor $\left(e_{s}\right)$, calculada com $T_{d}$, tem-se a pressão atual de vapor $\left(e_{a}\right)$. Teoricamente o equipamento é bastante preciso, mas devido a grande sensibilidade às variações das condições atmosféricas, o espelho muda facilmente sua propriedade de reflexão, a ponto de prejudicar sua calibração e gerando desta maneira, valores imprecisos. Outra modificação necessária consistiu no aumento da altura da torre que suporta os sensores. Na sua configuração original e construída com três metros de altura, para culturas de pequeno porte, porém, para o maracujazeiro em espaldeira a dois metros de altura, houve necessidade de aumentá-la para cinco metros de altura. 
Montaram-se duas torres, uma na parcela Norte-Sul e outra na Leste-Oeste. Elas foram instaladas entre duas plantas de linhas sucessivas (Figura 1). A diferença de temperatura entre os dois níveis foi medida com termopares de cobre-constantan instalados em psicrômetros aspirados, construídos de acordo com Marin et al. (2001). A voltagem diferencial gerada pelos termopares era produzida pela diferença de temperatura entre os níveis T1 e T2, para os termopares seco, e T1' e T2' para os molhados (Figura 2). A resolução das medidas de temperatura depende da resolução do datalogger, sendo nos equipamentos utilizados neste experimento, cerca de $0,006{ }^{\circ} \mathrm{C}$ com $0,1 \mu \mathrm{V}$ de ruído.

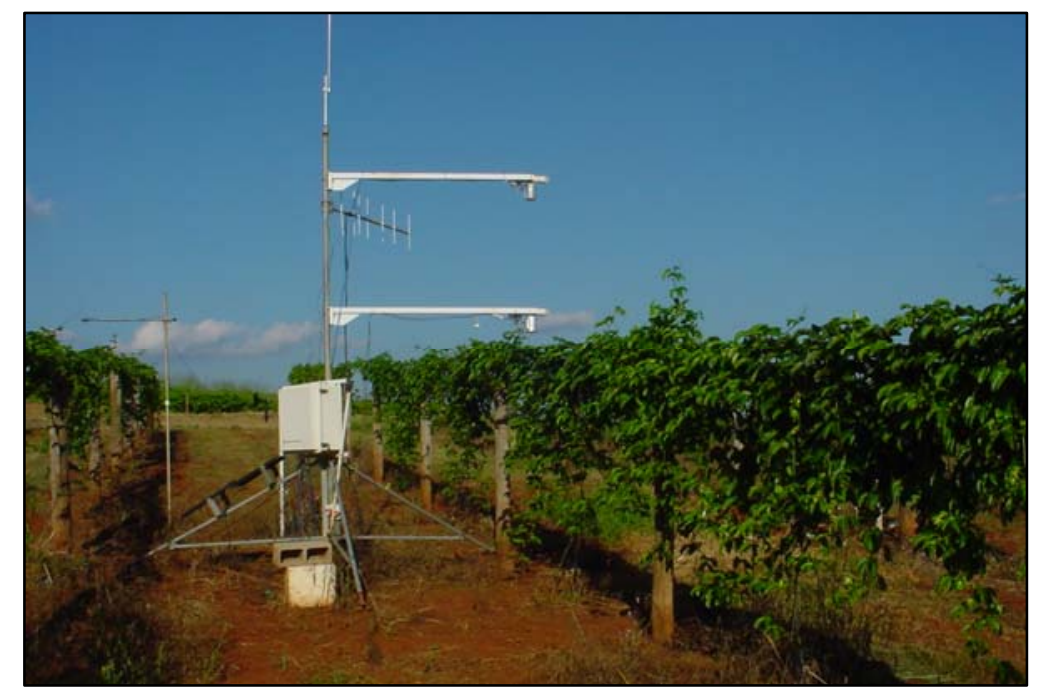

Figura 1 - Localização da torre e exposição dos sensores utilizados no método "Razão de Bowen-Balanço de Radiação” (RBBR)
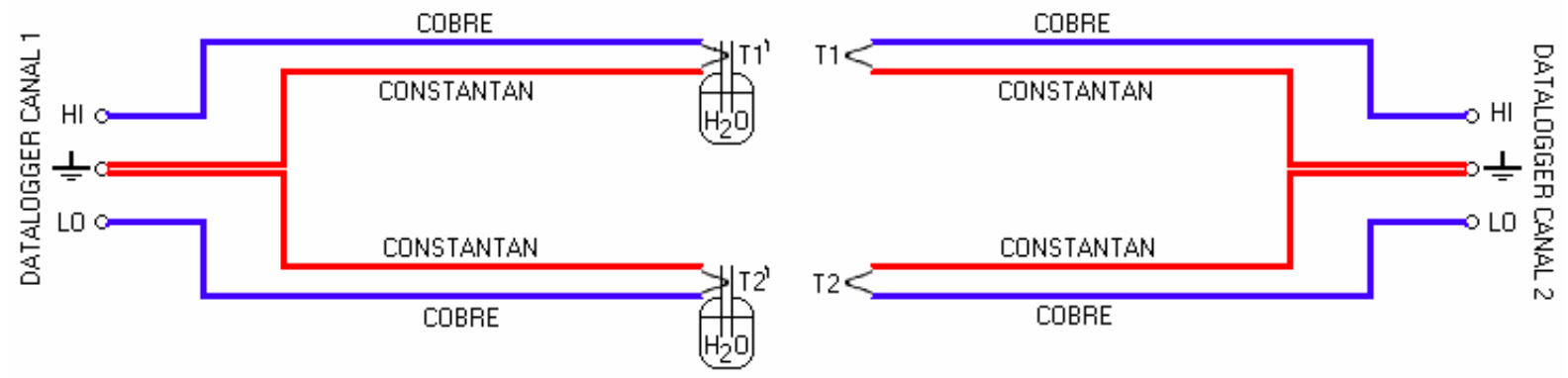

Figura 2 - Configuração dos psicrômetros e esquema de ligação dos termopares de bulbo seco (T) e úmido ( $T^{\prime}$ )

O saldo de radiação em cada parcela foi determinado com saldo-radiômetro, modelo Q7.1 - Radiation and Energy Balance Systems (Figura 3A). Eles foram instalados 
em tubos de aço galvanizado de $25 \mathrm{~mm}$ de diâmetro e 2,5 $\mathrm{m}$ de altura, de modo que a cúpula do saldo-radiômetro ficava a $0,5 \mathrm{~m}$ acima da planta. Eles foram posicionados na direção Norte, nas duas parcelas, de forma que a sombra do tubo do suporte não incidisse sobre a cúpula.

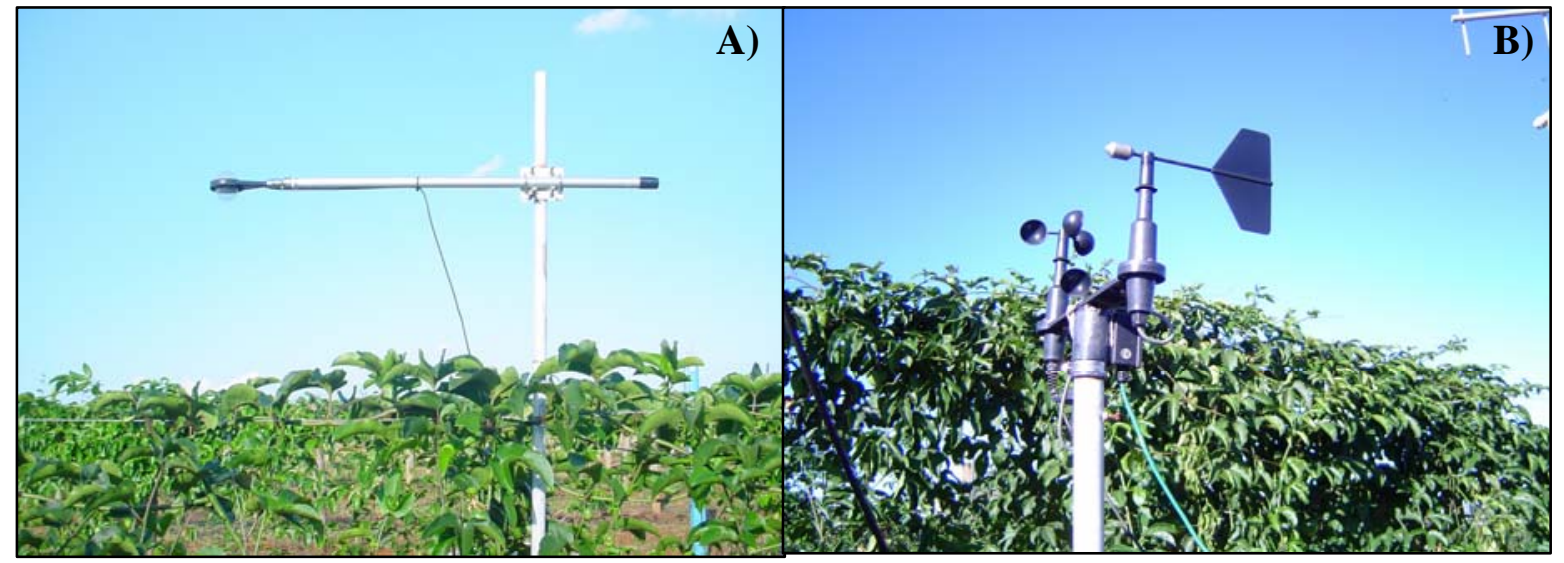

Figura 3 - Detalhe dos sensores de saldo de radiação (A), velocidade e direção de vento (B)

Em cada parcela instalou-se um anemômetro de canecas e um sensor de direção de vento (modelo 03001 Wind Sentry anemometer and Vane, R. M. Young, Traverse City, Michigan EUA). Os sensores de direção e velocidade de vento foram instalados próximo à torre de suporte dos psicrômetros, na altura de $1 \mathrm{~m}$ do solo, entre duas fileiras de plantio. Os sensores de vento encontravam-se fixos em um suporte horizontal fornecido pelo fabricante (Figura 3B).

Geralmente a técnica mais utilizada para determinar o fluxo de calor no solo $(G)$ é conhecida como método combinado. Este método utiliza uma placa de fluxo de calor do solo, enterrada numa profundidade de 0,05 - 0,1 m na qual também é contabilizado o armazenamento de calor acima da placa, por meio de termopares de solo. Silans et al., (1997) não encontrou diferenças significativas entre os valores de evapotranspiração estimados com o método de balanço de energia pela razão de Bowen, quando utilizaram o $G$ obtido pelo método combinado ou por placas enterradas a 0,025 m. Frizina e Escobedo, (1999) avaliaram o balanço de radiação na cultura de alface, sendo o $G$ obtido com placas de fluxo de calor instaladas a 0,01 $\mathrm{m}$ de profundidade. Neste experimento o $G$ foi obtido pelo valor médio dado apenas por duas placas (HFT3, Rebs, Seattle, Washington, EUA) enterradas próximo a superfície do solo, a 0,02 m, sendo uma a 0,2 $\mathrm{m}$ distante do tronco da 
planta no lisímetro e outra, a mesma profundidade e distância, na planta sob o saldo radiômetro.

Todos os sensores foram acoplados aos sistemas de aquisição eletrônica de dados “dataloggers” (ambos modelo CR23X Campbell Scientific, Logan, Utah, EUA) alimentados por baterias automotivas externas (DFA45D, 12V, 45 Ah, Delphi Automotive Systems do Brasil, São Paulo, BR) carregadas diariamente por painel solar (MSX20R, Campbell Scientific, Logan, Utah, EUA). Os “dataloggers” foram programados para efetuar leituras de todos os sensores a cada segundo e armazenar seus valores médios a cada 10 minutos. Os sistemas de aquisição foram conectados aos conversores de sinal (RF95, Campbell Scientific, Logan, Utah, EUA) e transmissores/receptores de dados (UHF RECEIVER DL-3410, Johnson data telemetry, Waseca, MN, EUA), estes enviavam sinais de rádio para uma estação base (modelo RF232 Campbell Scientific, Logan, Utah, EUA), localizada no laboratório de aquisição de dados distante de $3 \mathrm{~km}$ do local do experimento.

\subsubsection{Critério para rejeição de dados inadequados do método RBBR}

O presente estudo toma por base uma análise física do método para rejeitar valores inconsistentes, incluindo aqueles fora dos limites da resolução instrumental, conforme Perez et al. (1999). Segundo esses autores, a estimativa de $\lambda E$ e $H$ fornecida pelo método $R B B R$ deve ser consistente com a relação fluxo-gradiente, mas em algumas vezes as medidas dão sinais incorretos para estes fluxos. As Equações 1 e 3 podem ser arranjadas resultando:

$$
\begin{aligned}
& R n=\left(1+\gamma \frac{\Delta T}{\Delta e}\right) \lambda E+G \\
& \frac{\Delta e}{\Delta E}=\gamma \frac{\Delta T}{H}=\frac{\Delta e+\gamma \Delta T}{R n-G}>0
\end{aligned}
$$

A relação $\Delta e / \Delta E$, representada pela Equação 7 deve sempre ser maior que 0 , de acordo com a conversão de sinais (Figura 4). Os dados fornecidos pelo método $R B B R$ serão 
corretos, quando atendem a desigualdade acima. Conseqüentemente, quando $R n-G>0, \Delta T$ $>-\Delta e / \gamma$. Isso é, $\beta>-1$ se $\Delta e>0$, mas $\beta<-1$ se $\Delta e<0$. Quando $R n-G<0, \Delta T<-\Delta e / \gamma$. Isso é, $\beta<-1$ se $\Delta e>0$, mas $\beta>-1$ se $\Delta e<0$. Conseqüentemente, as Equações 1 e 2 , mostram que apenas algumas combinações de valores de $H$ e $\lambda E$ são possíveis (Tabela 1).

(a) Quando $R n-G>0$ : Se $\beta>-1$, da Equação 5, é deduzido que $\lambda E$ deve ser sempre positivo, visto que $H$ pode ser positivo ou negativo (Equação 2) dependendo do sinal de $\beta$. Se $\beta<-1$, são possíveis apenas os casos $\lambda E>$ 0 e $H>0$.

(b) Quando $R n-G<0$ : Se $\beta<-1$, são apenas possíveis os casos $\lambda E>0$ e $H<$ 0 . Se $\beta>-1$ então $\lambda E$ será sempre negativo, visto que $H$ pode ser positivo ou negativo dependendo do sinal de $\beta$.

Se estas condições não forem satisfeitas (Tabela 1), o $R B B R$ fornecerá uma direção incorreta de fluxo, e os dados serão descartados. Isto apenas ocorre no início da manhã e ao entardecer, quando o fluxo de calor muda de sinal; durante a irrigação ou precipitação onde $\Delta e$ apresenta valores baixos (próximo do limite de resolução $\delta \Delta e$ ); e quando os valores de $R n-G$ são baixos.

Tabela 1. Condições de aceitabilidade dos valores obtidos pelo método $R B B R$ sob condições não advectivas de acordo com a Equação 7

\begin{tabular}{cccc}
\hline $\begin{array}{c}\text { Energia } \\
\text { disponível }\end{array}$ & $\begin{array}{c}\text { Gradiente } \\
\text { de pressão } \\
\text { de vapor }\end{array}$ & $\begin{array}{c}\text { Razão de } \\
\text { Bowen }\end{array}$ & Fluxos de calor \\
\hline$R n-G>0$ & $\Delta e>0$ & $\beta>-1$ & $\lambda E>0$ e $H \leq 0$ para $-1<\beta \leq 0$ ou $H>0$ para $\beta>0$ \\
& $\Delta e<0$ & $\beta<-1$ & $\lambda E<0$ e $H>0$ \\
$R n-G<0$ & $\Delta e>0$ & $\beta>-1$ & $\lambda E>0$ e $H<0$ \\
& $\Delta e<0$ & $\beta<-1$ & $\lambda E<0$ e $H \geq 0$ para $-1<\beta \leq 0$ ou $H<0$ para $\beta>0$
\end{tabular}

$R n$ - saldo de radiação; $G$ - fluxo de calor no solo; $\Delta e$ - diferença de pressão de vapor entre os níveis superior e inferior; $\lambda E$ e $H$ - fluxos de calor latente e sensível, respectivamente 


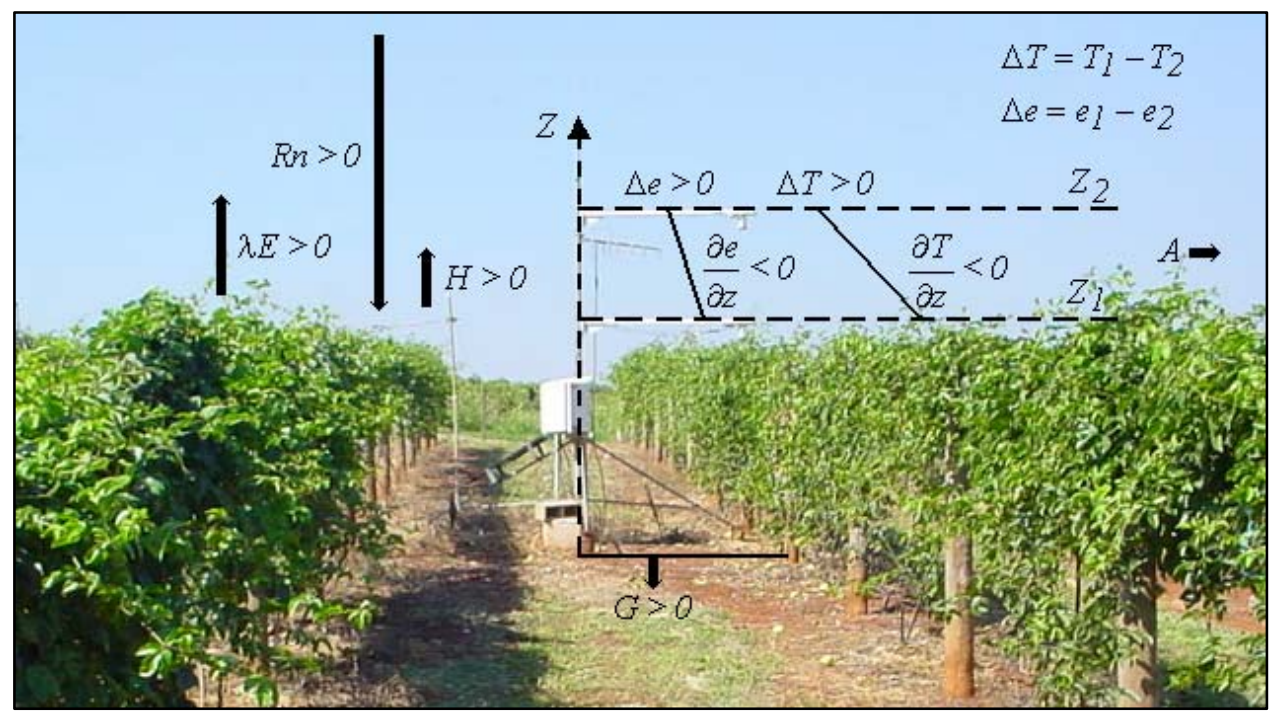

Figura 4 - Representação dos fluxos de energia na interface entre o ar e a superfície vegetal mostrando a convenção de sinais. (A) representa o fluxo de energia advectiva para o volume de controle acima da superfície; $(R n)$ o saldo de radiação; $(\lambda E)$ e $(H)$ são os fluxos de calor latente e sensível; $(G)$ fluxo de calor no solo; $(\Delta)$ e $(\Delta T)$ a diferença de pressão de vapor e temperatura entre os níveis inferior $\left(\mathrm{Z}_{1}\right)$ e superior $\left(Z_{2}\right)$ e $(\partial e / \partial z)$ e $(\partial T / \partial z)$ corresponde aos gradientes de pressão de vapor e temperatura

Para analise dos dados e exclusão de valores de $\beta$ inconsistentes, utilizou-se as condições propostas por Perez et al., (1999), resumidas na Tabela 2. Estas condições foram incorporadas na lógica de programação em planilha eletrônica para identificação da classe de erro e exclusão do valor.

Tabela 2. Resumo das classes de erros gerados pelo método RBBR (Perez et al., 1999)

\begin{tabular}{cl}
\hline Classe de erro & Condição \\
\hline$A$ & $(R n-G)>0, \Delta e>0$ e $\beta<-1+|\varepsilon|$ \\
$B$ & $(R n-G)>0, \Delta e<0$ e $\beta>-1-|\varepsilon|$ \\
$C$ & $(R n-G)<0, \Delta e>0$ e $\beta>-1-|\varepsilon|$ \\
$D$ & $(R n-G)<0, \Delta e<0$ e $\beta<-1+|\varepsilon|$ \\
$E$ & Mudanças rápidas em $T$ e $e$ \\
\hline
\end{tabular}

$R n-G$ : é a energia disponível; $\Delta e$ : diferença de pressão de vapor entre o nível superior e inferior; $\beta$ : razão de Bowen; $T$ e $e$ : temperatura do ar e pressão de vapor; $\varepsilon$ : intervalo de erro que define o intervalo de exclusão dos valores da razão de Bowen; $\lambda \mathrm{E}$ e $H$ : fluxos de calor latente e sensível, respectivamente 


\subsection{Resultados e Discussão}

A partição dos componentes do balanço de radiação sobre a cultura do maracujazeiro para 12 meses de cultivo está representada pelas variações ao longo de um dia escolhido como representativo do mês, entre o $15^{\circ}$ e o $20^{\circ}$ dia, nas figuras 5 a 8.

As curvas das Figuras 5 a 8 estão agrupadas em período trimestral, de acordo com as estações do ano, para as duas orientações de plantio (Norte-Sul ou Leste-Oeste).

No verão (Figura 5), observando a variação do saldo de radiação $(R n)$, pode-se identificar que um maior recobrimento do céu (incidência de nuvens) acontecia após o meio-dia. A densidade de fluxo do $R n$ média do período variou de 764 a $-56 \mathrm{~W} \mathrm{~m}^{-2}$. No outono, representado pela Figura 6, o recobrimento do céu distribuiu-se ao longo do dia, causando flutuações no $R n$ tanto pela manhã, quanto à tarde. Nesta estação a densidade de fluxo do $R n$ média do período variou de 646 a $-39 \mathrm{~W} \mathrm{~m}^{-2}$. Os menores valores de $R n$ aconteceram no inverno (Figura 7), alcançando de $476 \mathrm{a}-56 \mathrm{~W} \mathrm{~m}^{-2}$, para o maior e menor valor de densidade de fluxo, respectivamente. Ainda nesta estação, a curva da densidade de fluxo do $R n$ não apresentou oscilações causadas pela interceptação da radiação solar por nuvens, caracterizando assim, uma condição de céu “aberto”, típico de dias frios da estação de inverno. Com a chegada da primavera (Figura 8) verifica-se aumento na densidade de fluxo do $R n$, sendo $682 \mathrm{~W} \mathrm{~m}^{-2}$ o maior valor e $-49,82 \mathrm{~W} \mathrm{~m}^{-2}$ o menor valor médio do período.

Quando adulto, os maracujazeiros promoveram sombreamento do solo devido ao maior índice de área foliar da cultura, que teve grande incremento de área foliar após 176 DAP (17/04/04), ainda na estação de outono. O aumento de área foliar afetou o fluxo de calor no solo $(G)$, que promoveu variações distintas para as orientações de plantio. 

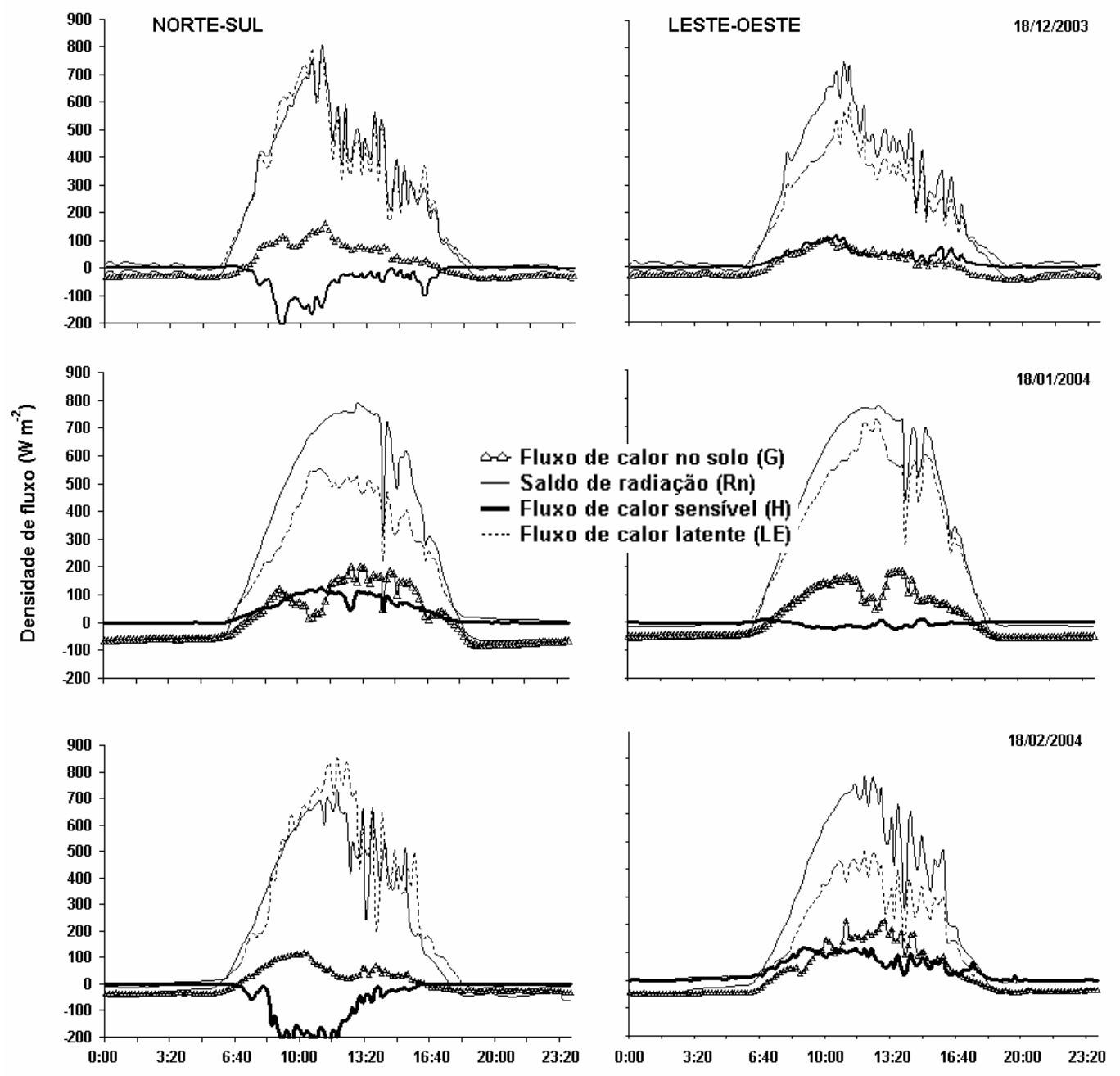

Hora local

Figura 5 - Saldo de radiação $(R n)$, fluxo de calor no solo $(G)$, fluxo de calor sensível $(H)$ e fluxo de calor latente $(\lambda E)$ nos dias 18/12/03, 18/01/04 e 18/02/04, na estação de verão

Observa-se no dia 16/08/2004, por exemplo, que a variação do $G$ no cultivo com linhas Norte-Sul estava relacionada com o sombreamento do solo abaixo da linha de cultivo. Nesse dia verificou-se que o $G$ aumentava a partir do amanhecer até a metade da manhã (@10:30), decrescendo para o meio dia, voltando a aumentar do início da tarde até sua metade (15:30), e novamente decrescendo para o final do dia. 

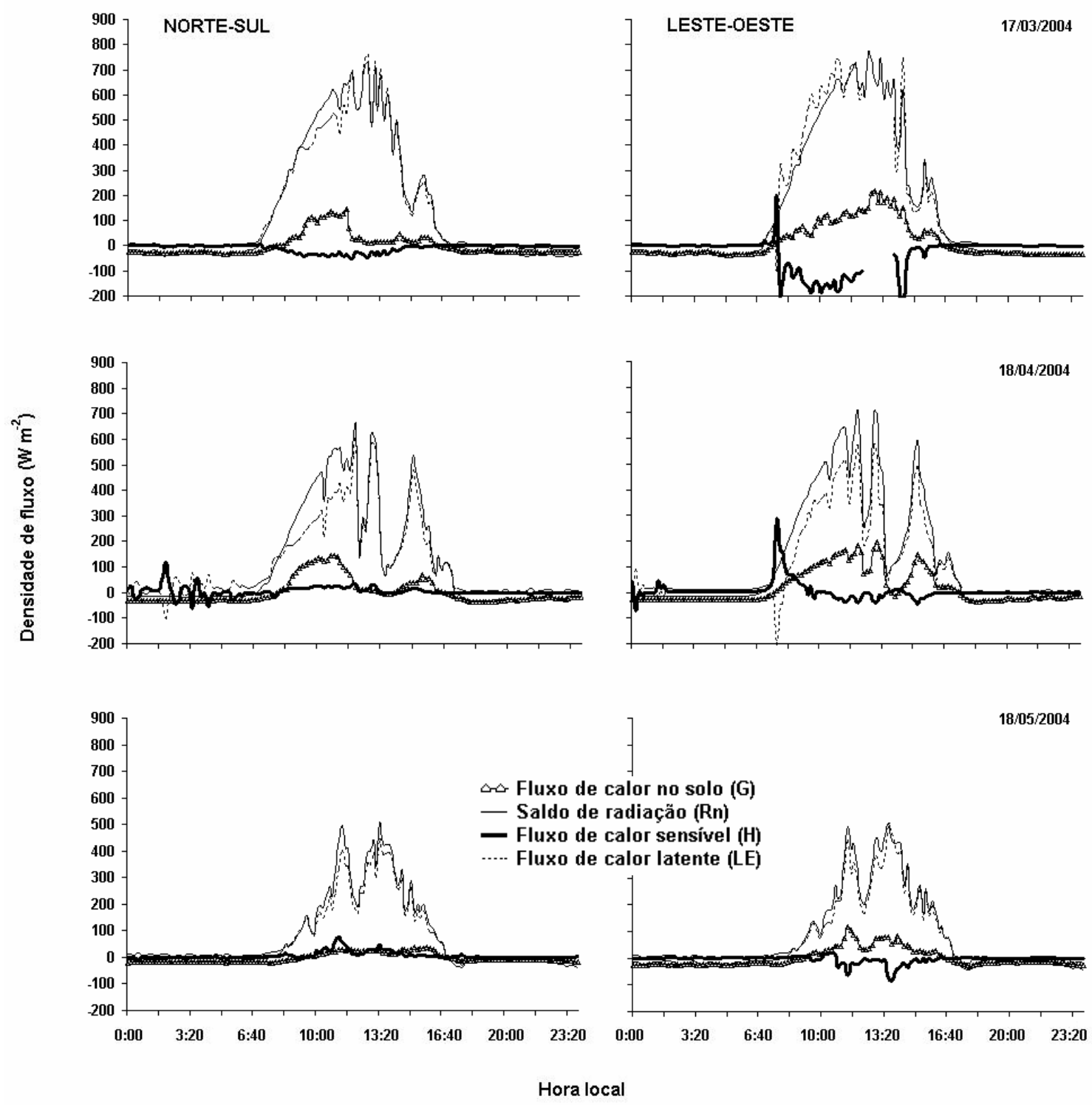

Figura 6 - Saldo de radiação $(R n)$, fluxo de calor no solo $(G)$, fluxo de calor sensível $(H)$ e fluxo de calor latente $(\lambda E)$ nos dias 17/03/04, 18/04/04 e 18/05/04, na estação de outono

Nesta condição a variação do $G$ durante o período de brilho solar, determinava uma curva semelhante a uma senóide. No cultivo orientado em Leste-Oeste, o $G$ aumentava progressivamente a partir do início da manhã, atingia máximo valor próximo do meio-dia, e decrescia progressivamente até o final da tarde. Dessa forma a variação do $G$ no período do dia descrevia uma curva parabólica. Neste último caso, o $G$ era fortemente afetado pela 
radiação incidente, que em função da latitude local e variação da declinação solar no período, tinha sua sombra sempre deslocada para o lado Sul das linhas de cultivo. Esta condição não proporcionava sombreamento abaixo da cultura, como verificado ao meio-dia no cultivo com linhas orientadas Norte-Sul.

De maneira geral, o maior valor de $G$ foi $216 \mathrm{~W} \mathrm{~m}^{-2}$, que ocorreu no mês de março/04 no início do outono, e $-81 \mathrm{~W} \mathrm{~m}^{-2}$ o menor fluxo, em janeiro/05.
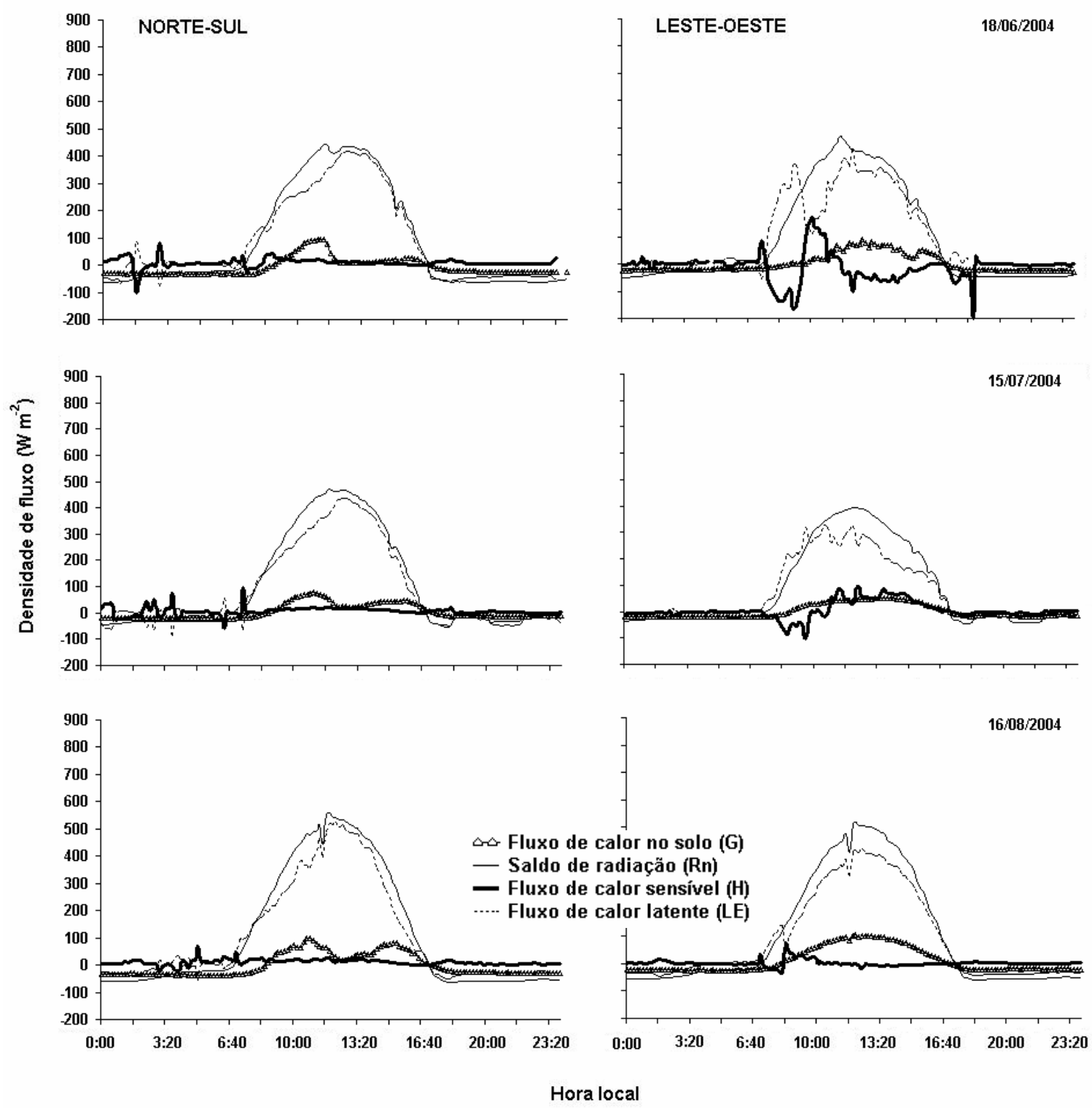

Figura 7 - Saldo de radiação $(R n)$, fluxo de calor no solo $(G)$, fluxo de calor sensível $(H)$ e fluxo de calor latente ( $\lambda E$ ) nos dias 18/06/04, 15/07/04 e 16/08/04, na estação de inverno 


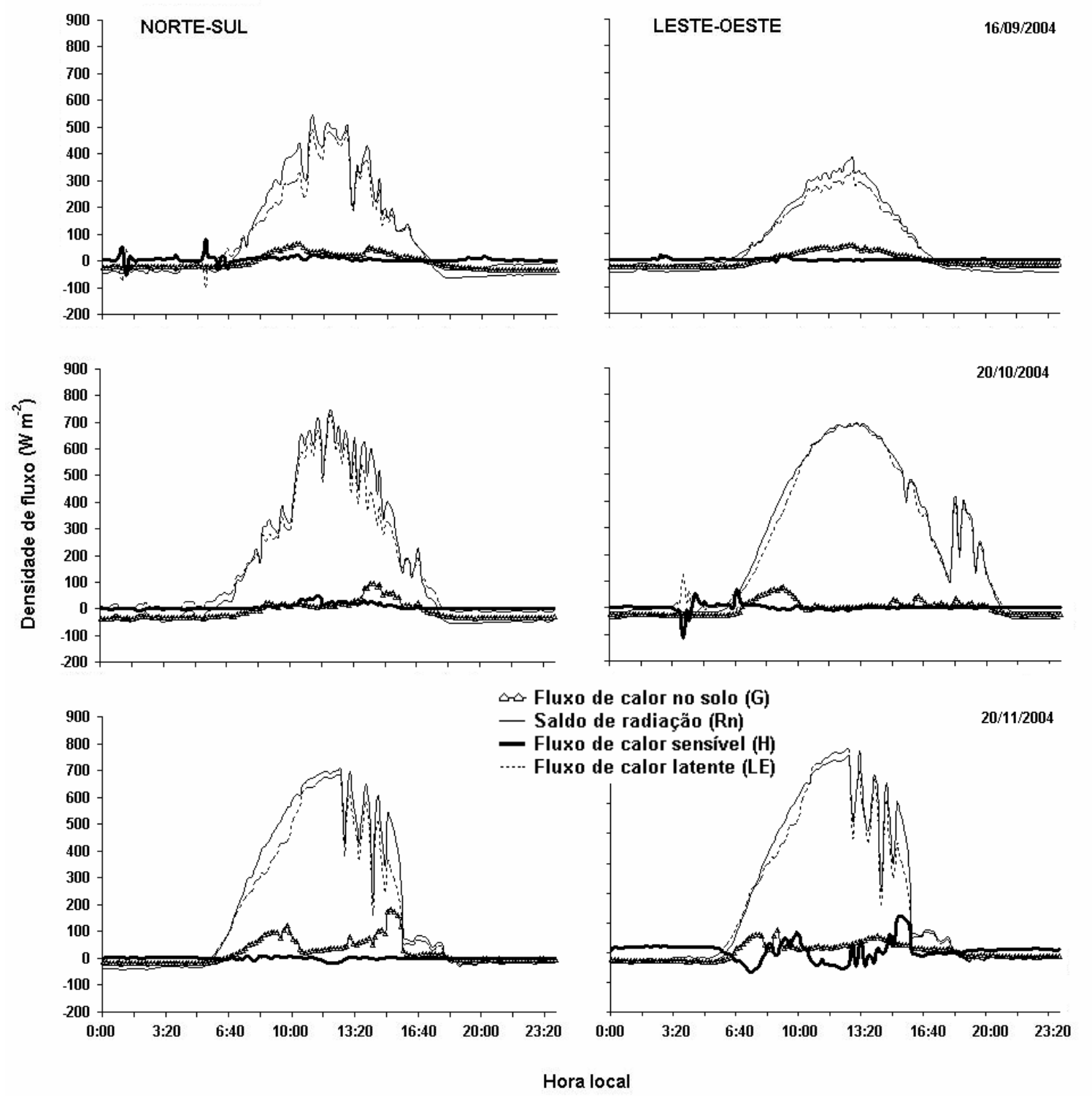

Figura 8 - Saldo de radiação $(R n)$, fluxo de calor no solo $(G)$, fluxo de calor sensível $(H)$ e fluxo de calor latente $(\lambda E)$ para os dias 16/09/04, 20/10/04 e 20/11/04, na estação de primavera

O fluxo de calor latente $(\lambda E)$ apresentou-se de maneira semelhante às curvas de $R n$, com grande participação no balanço de energia. O maior valor registrado foi de $854 \mathrm{~W}$ $\mathrm{m}^{-2}$ no mês de dezembro de 2004 e o menor $-204 \mathrm{~W} \mathrm{~m}^{-2}$, em abril/04. Houve alguns casos em que o $\lambda E$ superou o $R n$. Estas situações ocorreram no verão quando o fluxo de calor 
sensível $(H)$ atingiu valores mais negativos, principalmente, após as chuvas ou irrigações. O $\lambda E$ superou o $R n$ também nos dias 18/12/03 e 18/02/04 para o cultivo Norte-Sul (Figura 5). Nestes dias não ocorreram chuvas, porém, coincidiu com a irrigação realizada na parcela.

A Figura 9 mostra o $R n$ total dos cultivos Norte-Sul e Leste-Oeste para os 14 meses de avaliação. As variações dos $R n$ durante o ano apresentaram valores-limite de: 5,28 a 13,52 $\mathrm{MJ} \mathrm{m}^{-2} \mathrm{dia}^{-1}$ para o cultivo com linhas Norte-Sul e 6,18 a 14,66 $\mathrm{MJ} \mathrm{m}^{-2} \mathrm{dia}^{-1}$ para o cultivo com linhas Leste-Oeste. Nota-se, pelas curvas de $R n$ que as variações foram aproximadamente similares para os dois sistemas de cultivo, com pequena superioridade para o $R n$ do cultivo Leste-Oeste até meados de Julho/04, sendo superado após esta data pelo $R n$ do cultivo Norte-Sul. Essa inversão foi promovida possivelmente pela diminuição do fluxo de calor no solo do cultivo Leste-Oeste, nas estações de inverno e primavera.

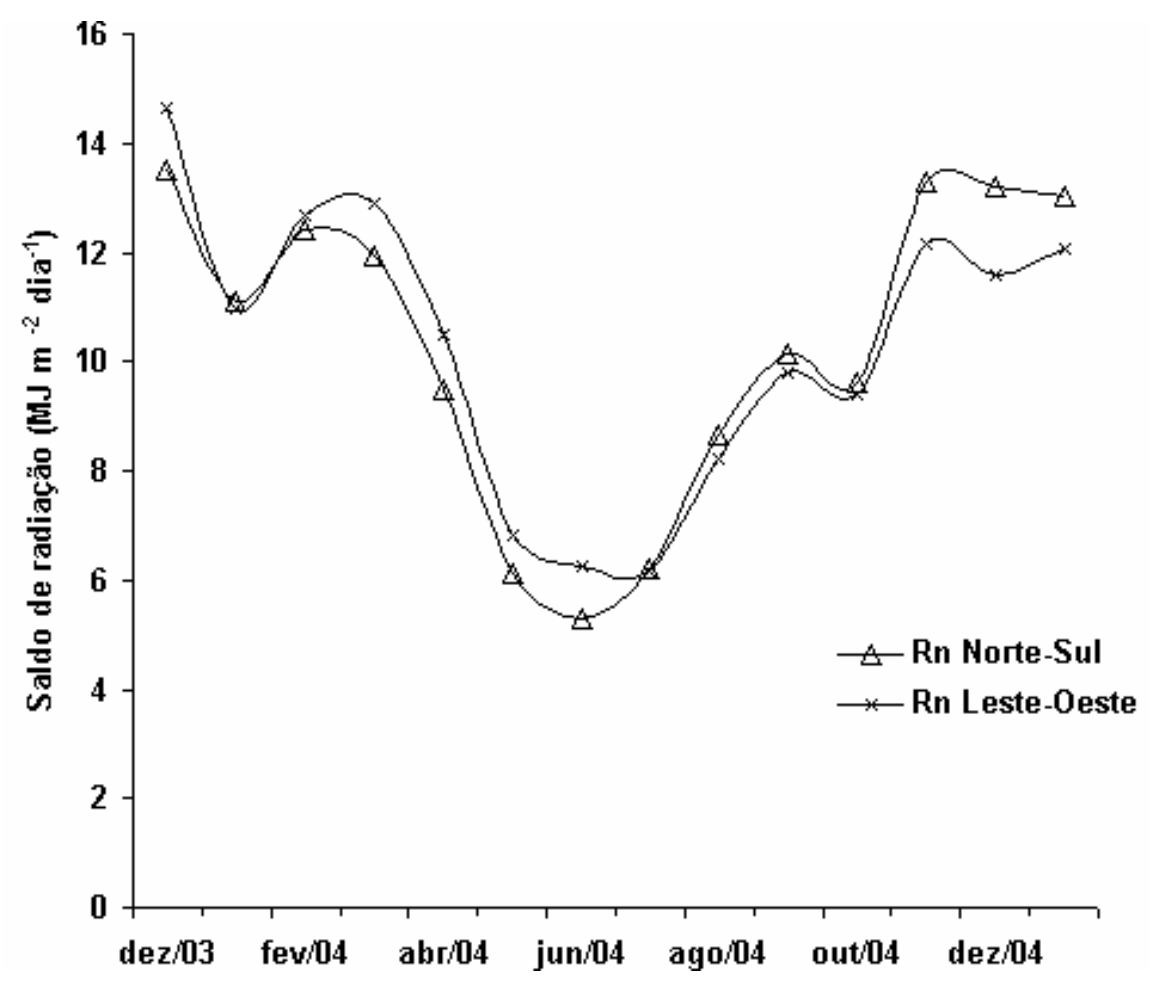

Figura 9 - Curvas de saldo de radiação $(R n)$, em $\mathrm{MJ} \mathrm{m}^{-2} \mathrm{dia}^{-1}$, para maracujazeiros cultivados com linhas orientadas na direção Norte-Sul e Leste-Oeste, durante 14 meses, em 2003 e 2004 
Nestas estações, ocorreu sombreamento abaixo das plantas do cultivo Leste-Oeste na maior parte do período diurno, conseqüentemente, menor incidência de radiação direta e menor armazenamento de calor no solo.

Realizando teste de hipótese (teste F), foi possível determinar que não houve diferenças significativas entre os valores de $R n$ e $L E$ para os dois sistemas de cultivo durante os meses do ano (Tabela 3). Os fluxos de calor no solo, médio mensal, para o cultivo Leste-Oeste foram superiores e diferiram significativamente desde o mês de fevereiro até agosto, ou seja, final de verão, outono e inverno.

Tabela 3. Valores médios mensais, em $\mathrm{MJ} \mathrm{m}^{-2} \mathrm{dia}^{-1}$, para o saldo de radiação (Rn) fluxo de calor no solo $(G)$; fluxo de calor latente $(L E)$ e fluxo de calor sensível $(H)$

\begin{tabular}{cccccccccc}
\hline \multicolumn{1}{c}{ NORTE-SUL } & \multicolumn{3}{c}{ LESTE-OESTE } \\
Data & $R n$ & $G$ & $L E$ & $H$ & $R g$ & $R n$ & $G$ & $L E$ & $H$ \\
\hline Dez/03 & 13,517 & 1,969 & 10,896 & 1,580 & 21,561 & 14,661 & $-0,172$ & 9,980 & $3,977^{*}$ \\
Jan/04 & 11,089 & 0,702 & 11,097 & $-0,710$ & 18,490 & 10,977 & 0,758 & 9,357 & $1,272^{*}$ \\
Fev/04 & 12,416 & 0,034 & 13,545 & $-1,163$ & 20,359 & 12,658 & $0,628^{*}$ & 17,009 & 0,406 \\
Mar/04 & 11,938 & $-0,223$ & 13,848 & $-1,687$ & 20,173 & 12,905 & $0,545^{*}$ & 13,427 & $0,958^{*}$ \\
Abr/04 & 9,479 & $-0,290$ & 9,244 & 0,526 & 15,771 & 10,474 & $0,534^{*}$ & 10,061 & $-0,123$ \\
Mai/04 & 6,138 & $-0,738$ & 6,242 & 0,634 & 11,165 & 6,806 & $-0,161^{*}$ & 7,145 & $-0,177$ \\
Jun/04 & 5,275 & $-0,513$ & 5,761 & 0,076 & 10,097 & 6,273 & $0,176^{*}$ & 7,472 & $-1,064$ \\
Jul/04 & 6,225 & $-0,432$ & 6,352 & 0,715 & 10,442 & 6,181 & $-0,104^{*}$ & 7,243 & $-0,212$ \\
Ago/04 & 8,654 & $-0,402$ & 8,538 & 0,518 & 15,524 & 8,217 & $0,463^{*}$ & 8,034 & $-0,280$ \\
Set/04 & 10,153 & 0,642 & 9,343 & 0,169 & 18,396 & 9,804 & 0,487 & 9,059 & 0,258 \\
Out/04 & 9,631 & $-0,079$ & 9,490 & 0,220 & 14,893 & 9,399 & $-0,174$ & 10,466 & $-0,917$ \\
Nov/04 & 13,293 & 0,363 & 12,936 & $-0,006$ & 20,149 & 12,144 & $-1,176$ & 14,419 & $-0,075$ \\
Dez/04 & 13,223 & 0,262 & 14,314 & $-1,353$ & 19,791 & 11,601 & $-0,172$ & 11,816 & 0,069 \\
Jan/05 & 13,012 & 0,004 & 12,797 & $0,211^{*}$ & 19,268 & 12,045 & 0,313 & 12,007 & $-0,231$ \\
Média & 10,289 & $-0,031$ & 10,315 & $-0,019$ & 16,863 & 10,296 & 0,139 & 10,535 & 0,276 \\
\hline
\end{tabular}

* Diferença significativa ao nível de 5\% de probabilidade (teste F).

Analisando os desvios-padrão dos valores médios mensais de Rn para os cultivos (Tabela 4), o Norte-Sul apresentou desvios de 1,543 a 4,825 $\mathrm{MJ} \mathrm{m}^{-2} \mathrm{dia}^{-1}$, e o cultivo LesteOeste de 1,398 a 5,021 $\mathrm{MJ} \mathrm{m}^{-2} \mathrm{dia}^{-1}$.

Relacionando os valores de saldo de radiação com a radiação global, obteve-se valores percentuais de $R n$ para os dois sistemas de cultivo. 
Tabela 4. Valores de desvio-padrão da radiação global $(R g)$ e do saldo de radiação $(R n)$ e seus componentes: Fluxo de calor no solo $(G)$; Fluxo de calor latente $(L E)$ e Fluxo de calor sensível $(H)$. Valores em $\mathrm{MJ} \mathrm{m}^{-2} \mathrm{dia}^{-1}$

\begin{tabular}{cccccccccc}
\hline & \multicolumn{4}{c}{ NORTE-SUL } & \multicolumn{4}{c}{ LESTE-OESTE } \\
Data & $R n$ & $G$ & $L E$ & $H$ & $R g$ & $R n$ & $G$ & $L E$ & $H$ \\
\hline Dez/03 & 3,880 & 5,171 & 4,737 & 5,012 & 5,842 & 1,873 & 1,092 & 3,068 & 2,821 \\
Jan/04 & 4,613 & 1,385 & 3,756 & 0,553 & 7,601 & 4,486 & 1,340 & 4,736 & 1,991 \\
Fev/04 & 4,279 & 0,949 & 4,553 & 1,783 & 7,025 & 4,065 & 1,214 & 26,062 & 7,320 \\
Mar/04 & 3,070 & 0,593 & 6,318 & 4,825 & 5,115 & 3,439 & 1,007 & 11,478 & 4,950 \\
Abr/04 & 2,690 & 0,591 & 4,436 & 3,156 & 4,348 & 3,182 & 1,050 & 2,943 & 1,424 \\
Mai/04 & 2,675 & 0,682 & 2,355 & 0,439 & 3,936 & 2,931 & 0,922 & 3,818 & 2,704 \\
Jun/04 & 2,544 & 0,534 & 3,269 & 2,093 & 3,262 & 2,359 & 0,730 & 6,004 & 5,410 \\
Jul/04 & 2,686 & 0,380 & 2,368 & 2,064 & 3,983 & 2,443 & 0,473 & 3,488 & 3,926 \\
Ago/04 & 1,543 & 0,574 & 1,566 & 0,603 & 2,559 & 1,398 & 0,501 & 2,464 & 2,301 \\
Set/04 & 1,804 & 2,052 & 1,640 & 2,184 & 2,630 & 1,789 & 0,598 & 1,863 & 1,158 \\
Out/04 & 4,346 & 1,048 & 3,889 & 0,431 & 6,812 & 4,250 & 0,532 & 6,273 & 3,398 \\
Nov/04 & 4,429 & 1,081 & 3,865 & 0,404 & 7,297 & 4,070 & 5,261 & 10,367 & 7,632 \\
Dez/04 & 3,919 & 1,001 & 5,632 & 5,702 & 7,192 & 4,901 & 0,662 & 5,396 & 1,870 \\
Jan/05 & 4,825 & 0,480 & 4,599 & 0,628 & 6,225 & 5,021 & 0,638 & 5,015 & 0,348 \\
Média $(D P)$ & 3,632 & 1,122 & 4,069 & 2,037 & 5,735 & 3,567 & 1,103 & 6,909 & 3,080 \\
Média (CV) & 33,898 & 11,003 & 37,523 & 21,004 & 52,166 & 33,236 & 10,899 & 64,560 & 36,533 \\
\hline As repetições correspondem ao número de dias do mês (n= 30 ou 31). DP: Desvio-padrão; $C V$ : \\
Coeficiente de variação. Os valores de radiação global foram medidos na estação meteorológica
\end{tabular}

Nas curvas da Figura 10, observa-se que o percentual do $R n$ variou pouco com as estações do ano, com valor médio de 60,41 e 60,92 \%, para os cultivos Norte-Sul e LesteOeste, respectivamente, ambos com desvio-padrão inferiores a 5\%. Azevedo et al. (1997), em Petrolina-PE, estudaram o saldo de radiação sobre uma cultura de videira, onde observaram aumento no percentual de $R n$ em relação à radiação global de 60 para $70 \%$ à medida que a cultura avançava do estádio inicial para o florescimento. Vale ressaltar que o cultivo estudado por estes autores foi conduzido em espaldeira horizontal, tipo caramanchão, que recobre totalmente a superfície do terreno, diferente da espaldeira vertical utilizada no cultivo de maracujazeiros. Para o espaçamento adotado ( $4 \times 4 \mathrm{~m}$ ), o cultivo permitiu grande exposição do terreno (75 a 80\%), conseqüentemente, menor reflexão da radiação que seria disponibilizada para saldo de radiação. 


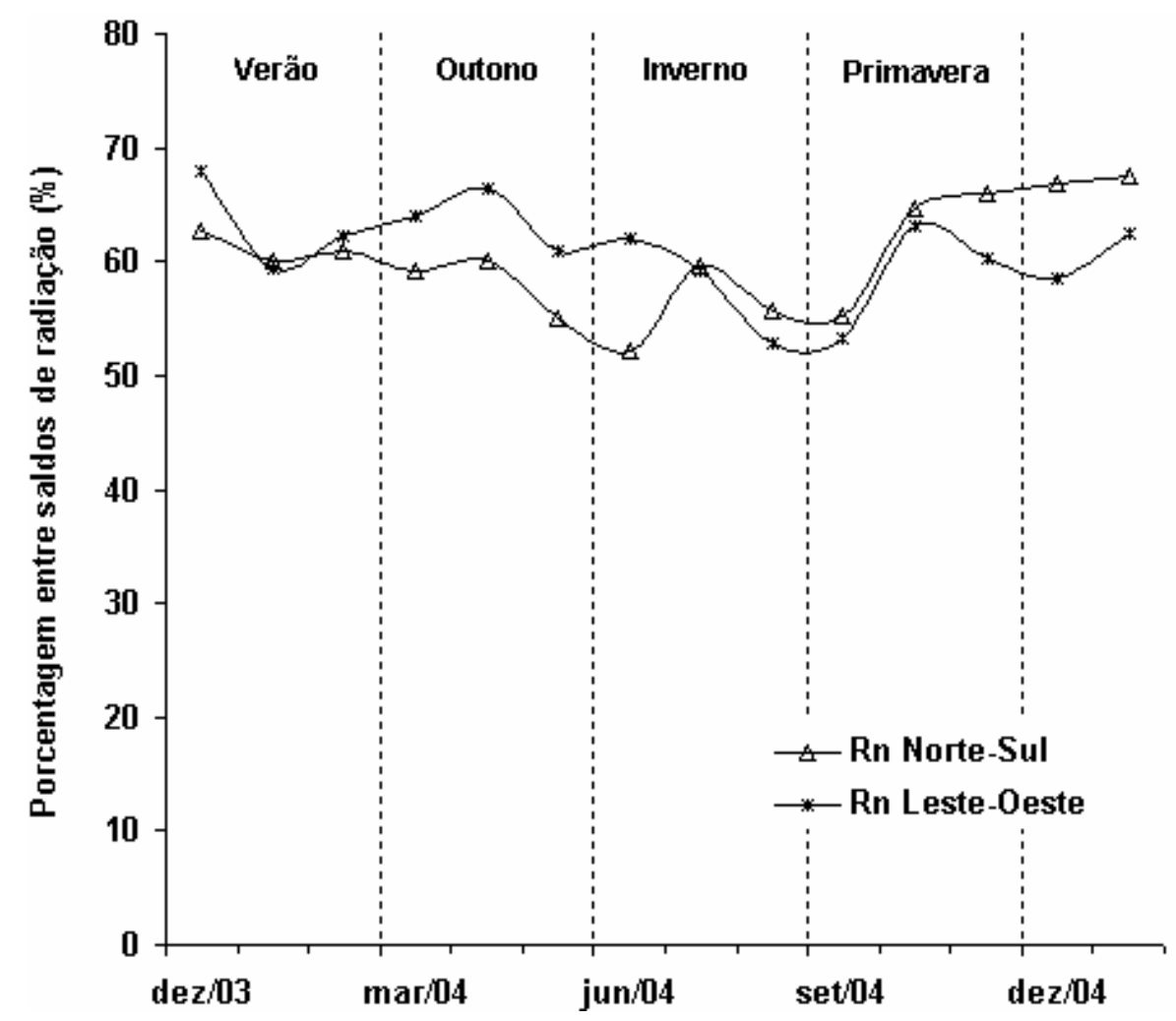

Figura 10 - Percentuais de saldo de radiação em relação à radiação global, nas estações do ano, sobre maracujazeiros cultivados em linhas Norte-Sul e Leste-Oeste, em Piracicaba-SP

Vale ressaltar que todos os valores fornecidos pela razão de Bowen durante períodos de 24 horas foram contabilizados integrando médias a cada 10 minutos, sem aplicar nenhum tratamento de exclusão de dados. Estes valores diários foram considerados repetições para comparações mensais utilizando um teste de hipótese (teste F). Dessa maneira, os fluxos de calor latente ( $L E)$ não diferiram para as orientações de cultivo durante a condução do experimento (Tabelas 3 e 4).

Analisou-se o fluxo de calor sensível $(H)$ da mesma forma que o $L E$. Em alguns meses do período chuvoso (dez/03, jan/04, mar/04) eles foram superiores, e diferentes estatisticamente aos $H$ do cultivo Norte-Sul e, em jan/05, o $H$ do cultivo Norte-Sul foi superior ao do Leste-Oeste. As causas devem-se ao umedecimento da superfície do solo e relações com o vento, princípios já discutidos anteriormente. 
Na Figura 11 observa-se a variação dos componentes do balanço de energia para os 12 meses de medida. Trata-se de uma representação gráfica dos valores diários que geraram a Tabela 4, e visualizados por linha de tendência tipo média móvel resultante do agrupamento de dados de 30 dias.
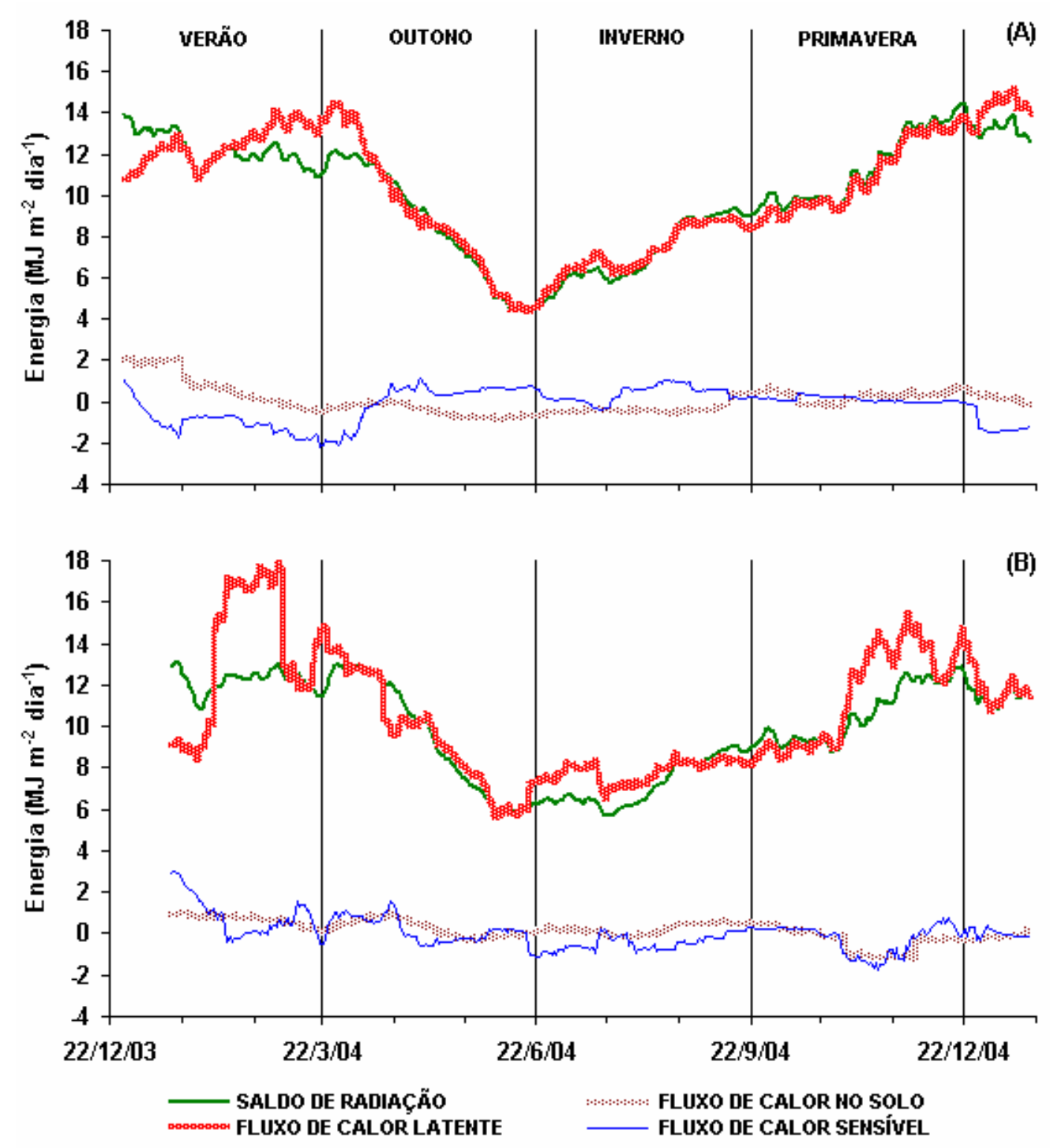

Figura 11 - Variação dos componentes do balanço de energia para os 12 meses de observação, sobre maracujazeiros com linhas de cultivo Norte-Sul (A) e Leste-Oeste (B)

A Figura 12 representa as curvas de percentuais da relação dos componentes $G$, $L E$ e $H$, com o saldo de radiação, para todos os meses do ano. Os percentuais médios anuais 
obtidos no cultivo Norte-Sul foram: $G / R n=-1,402 \%, L E / R n=100,669 \%$ e $H / R n=$ 0,847\%. No cultivo Leste-Oeste, os percentuais foram: $G / R n=1,353 \%, L E / R n=$ $103,633 \%$ e $H / R n=0,907 \%$. Nos dois sistemas de cultivo a soma dos percentuais dos componentes do balanço de energia ultrapassou 100 \%, o que indica uma sobreestimativa dos fluxos de calor latente e sensível, ou por influência de processos de advecção. Vários trabalhos com balanço de energia em cultivos, concluem que o maior percentual de radiação é transformado em fluxo de calor latente de evaporação (Teixeira, 1997; Cunha et al., 2002; Pezzopane \& Pedro Júnior, 2003).

Utilizando o critério de análise proposto por Perez et al., (1999), selecionou-se os intervalos de amostragem os valores de $\beta$ que se enquadravam nas classes de erro (Tabela 2). A Tabela 5 indica o número total de intervalos amostrados realizado em cada cultivo, a percentagem total de dados que apresentaram algum tipo de erro e, a percentagem dos dados falhos distribuídos por classe. Observa-se que, em média, 48,6 \% dos intervalos amostrados apresentaram algum tipo de erro. Deste total, mais de $90 \%$ dos casos foram dados do período da noite, quando o $R n-G$ era positivo ou negativo com inversão do gradiente de pressão de vapor $(\Delta e)$. Estes casos de erro aconteceram com maior freqüência, 45,6 \%, para o cultivo Norte-Sul e 34 \% para o Leste-Oeste (casos tipo B e C).
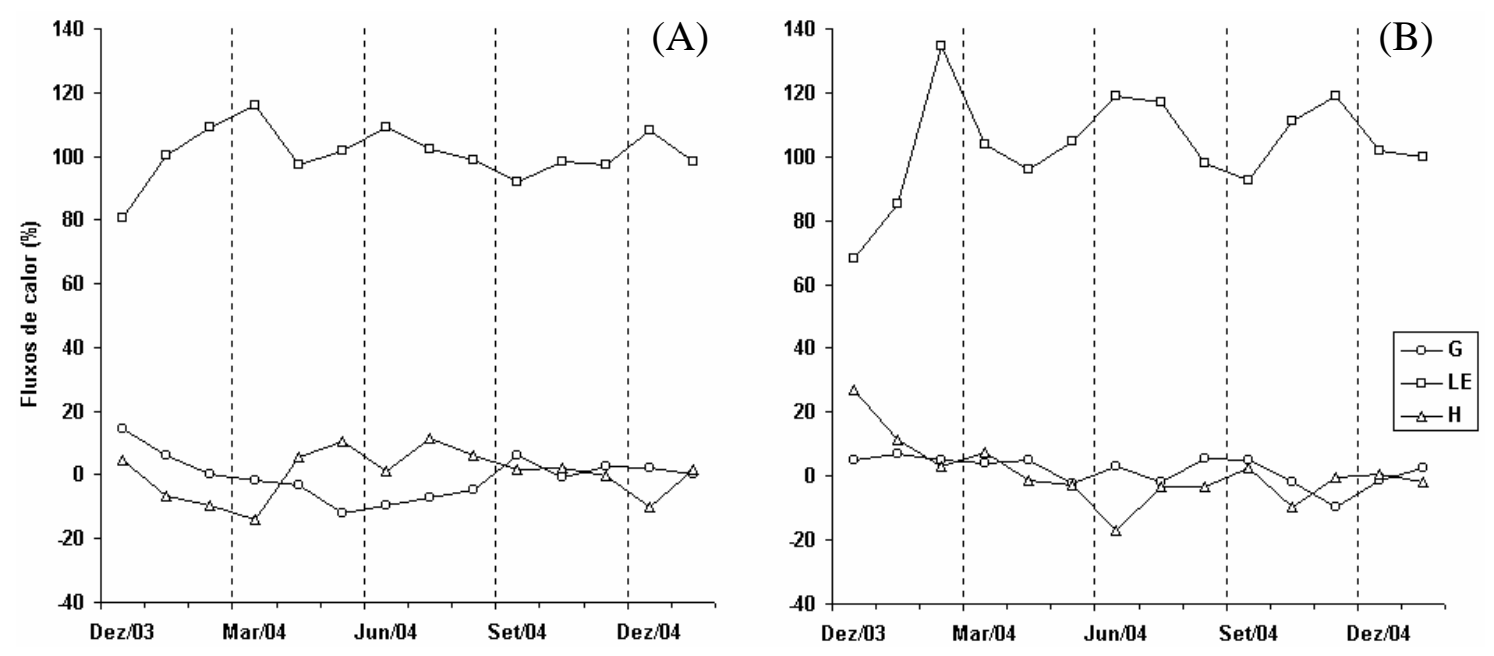

Figura 12. Curvas percentuais dos componentes de fluxo de calor latente $(L E)$, sensível $(H)$ e no solo $(G)$ em relação ao saldo de radiação, sobre maracujazeiros com linhas de cultivo Norte-Sul (A) e Leste-Oeste (B) 
Tabela 5. Percentagem de casos em que os dados fornecidos pelo método $R B B R$ enquadraram-se nos quatro tipos de erro, para duas orientações de cultivo de maracujazeiros, em Piracicaba-SP

\begin{tabular}{lccccc}
\hline Área (Orientação) & Total de erros (\%) & \multicolumn{4}{c}{ Erro (\%) } \\
& & $A$ & $B$ & $C$ & $D$ \\
\hline Norte-Sul (59799) & 53,20 & 7 & 25,5 & 20,10 & 0,4 \\
Leste-Oeste (57693) & 44,07 & 9 & 15 & 19 & 0,7 \\
Média & 48,6 & 8 & 20,25 & 14,55 & 0,55 \\
\hline
\end{tabular}

A condição mais comum durante o dia é quando $R n-G$ e $\Delta e$ são maiores que zero. Porém, em condição de instabilidade, se $\beta$ for inferior a $|\varepsilon|-1$, surgem casos associados ao erro tipo A. Este erro corresponde aos períodos imediatamente após a chuva ou irrigação, com participação inferior a $10 \%$ dos casos.

Os erros tipo $D$ tiveram participação muito baixa, inferiores a $1 \%$, e surgiram quando $R n-G$ foram menores que zero e o $|\varepsilon|-1$, maior que $\beta$. Perez et al., (1999), encontraram $15,13,12,5$ e $0,5 \%$ para os tipos de erro $A, B, C$ e $D$, respectivamente, valores médios de três localidades do norte da Espanha, com clima semi-árido e dados coletados sobre cultivos de pequeno porte (centeio). Os autores também relataram que os horários mais susceptíveis a erros pelo método $R B B R$ são os de final de tarde, durante a noite e ao amanhecer, quando o saldo de radiação e o fluxo de calor no solo mudam de sinal, casos também observados nesta pesquisa.

Ao realizar teste de hipóteses dos valores de evapotranspiração obtidos pelo método RBBR entre sistemas de cultivos (Norte-Sul Leste-Oeste), com e sem exclusão de intervalos de dados inconsistentes, foi possível identificar em que épocas do ano o efeito sistema de cultivo interferia no processo de evapotranspiração (Tabela 6).

Quando não se fez a análise dos intervalos de dados falhos fornecidos pelo método $R B B E$, não foi possível identificar diferenças entre os sistemas de cultivo. Mas, realizando a análise e eliminando os intervalos inconsistentes, identificaram-se diferenças significativas entre os sistemas para os meses de dezembro/03, janeiro, fevereiro, julho e agosto/04. 
Tabela 6. Evapotranspiração média mensal obtida pelo método Razão de Bowen-Balanço de Radiação $(R B B R)$, em maracujazeiros com linhas de cultivo orientadas Norte-Sul e Leste-Oeste, em Piracicaba-SP

\begin{tabular}{ccccc}
\hline & \multicolumn{2}{c}{ Intervalo completo } & \multicolumn{2}{c}{ Intervalo com dados selecionados } \\
& Norte-Sul & Leste-Oeste & Norte-Sul & Leste-Oeste \\
\hline Dez/03 & 5,41 & 4,24 & $5,81^{*}$ & 4,30 \\
Jan/03 & 4,50 & 3,56 & $4,60^{*}$ & 3,45 \\
Fev/04 & 5,42 & 4,08 & $5,24^{*}$ & 3,28 \\
Mar/04 & 5,21 & 4,26 & 5,26 & 4,58 \\
Abr/04 & 3,95 & 4,10 & 3,52 & 3,79 \\
Mai/04 & 2,59 & 2,86 & 2,62 & 2,49 \\
Jun/04 & 2,50 & 2,55 & 2,23 & 2,25 \\
Jul/04 & 2,52 & 2,76 & $2,71^{*}$ & 3,96 \\
Ago/04 & 3,55 & 3,35 & $3,88^{*}$ & 3,29 \\
Set/04 & 3,80 & 3,69 & 4,09 & 3,71 \\
Out/04 & 3,87 & 4,26 & 3,87 & 5,25 \\
Nov/04 & 4,67 & 3,36 & 5,52 & 3,52 \\
Média & 4,00 & 3,59 & 4,11 & \\
\hline
\end{tabular}

* Diferenças significativas pelo teste $\mathrm{F}$ ao nível de 5\% de probabilidade

Nas Figuras 13 e 14 observa-se a variação da evapotranspiração da cultura para os 12 meses de medida por meio de representação gráfica dos valores diários que geraram os valores médios da Tabela 5.

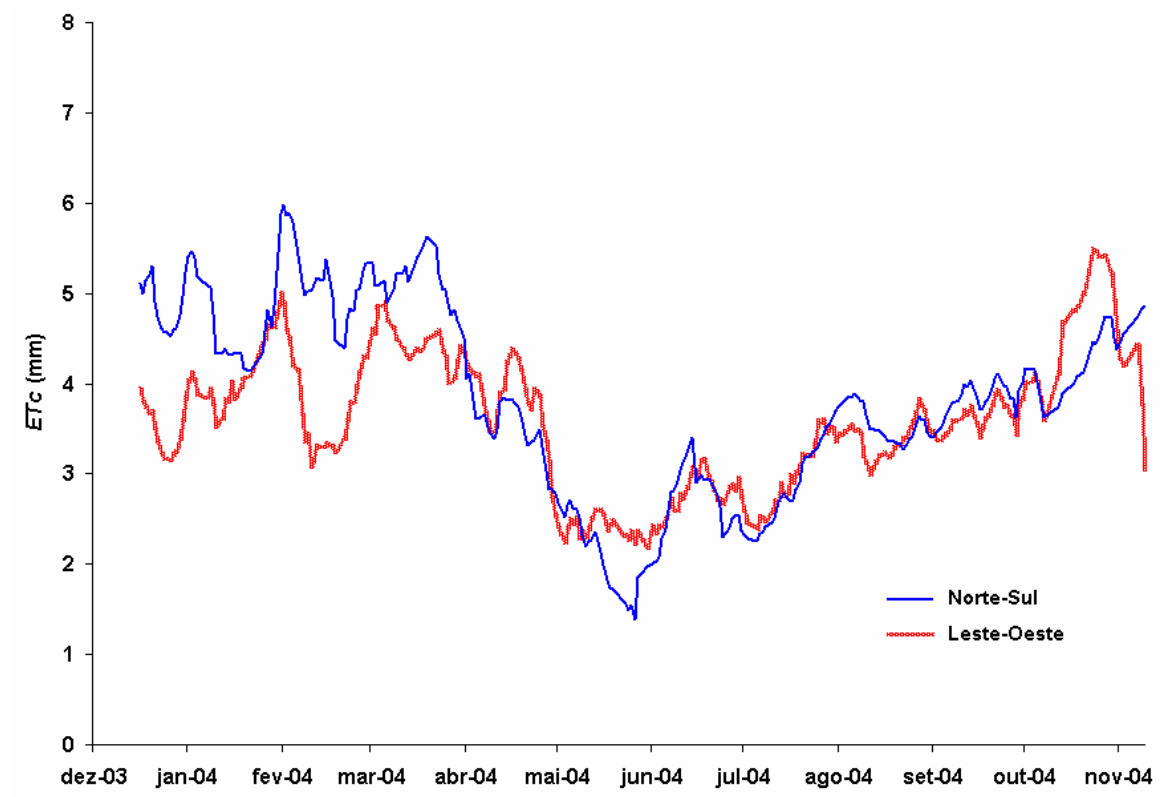

Figura 13 - Curvas de evapotranspiração de maracujazeiros com linhas de cultivo orientadas Norte-Sul e Leste-Oeste obtidas pelo método Razão de BowenBalanço de Radiação (intervalo completo), em Piracicaba-SP 
Ajustaram-se os intervalos de dados com linha de tendência média móvel resultante do agrupamento de 15 dados. Na Figura 13, utilizou-se todos os intervalos gerados pelo método RBBR (intervalo completo), enquanto a Figura 14 apenas os dados selecionados (intervalo com dados selecionados).

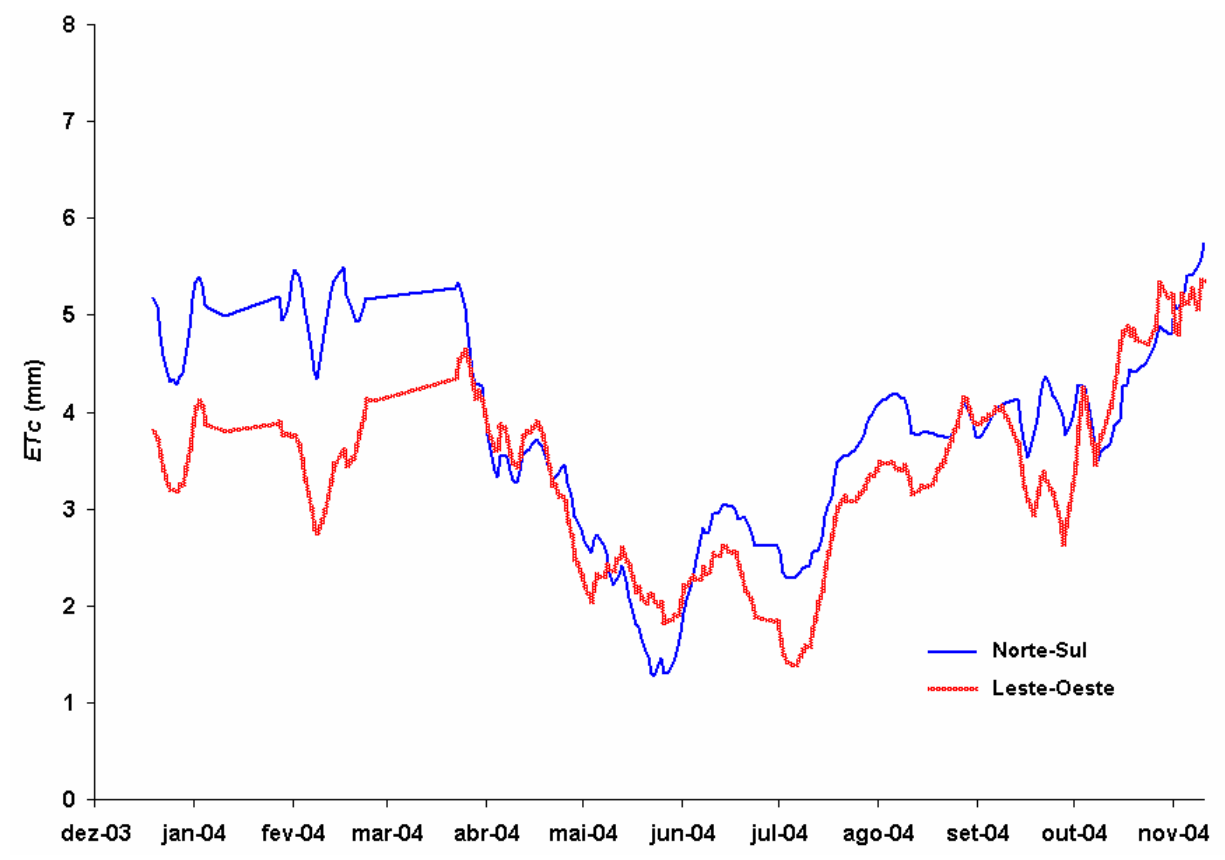

Figura 14 - Curvas de evapotranspiração de maracujazeiros com linhas de cultivo orientadas Norte-Sul e Leste-Oeste obtidas pelo método Razão de BowenBalanço de Radiação (intervalo com dados selecionados), em Piracicaba-SP

A evapotranspiração média dos sistemas cultivos, nas estações de verão, outono, inverno e primavera foram de 5,19, 2,08, 3,56 e 5,06 mm, respectivamente. A máxima evapotranspiração, 5,81 mm, ocorreu no verão, para o cultivo Norte-Sul e a mínima, 1,96 $\mathrm{mm}$, ocorreu no inverno, para o cultivo Leste-Oeste. Considerando-se todo o período analisado (14 meses), a evapotranspiração de maracujazeiros com linhas de cultivo orientadas no sentido Leste-Oeste foi 87,25\% da evapotranspiração do cultivo Norte-Sul. 


\subsection{Conclusões}

O saldo de radiação sobre cultivo de maracujazeiros não foi influenciado pelo sistema de plantio Norte-Sul ou Leste-Oeste. Seu valor foi equivalente a $60 \%$ da radiação global, durante as estações do ano, em Piracicaba-SP.

O componente de maior contribuição no balanço de radiação foi o calor latente de evaporação, utilizando cerca de $100 \%$ da energia disponível. O fluxo de calor sensível tem participação mínima no balanço de radiação e os valores mais significativos ocorrem imediatamente após as chuvas ou irrigações. O fluxo de calor no solo médio, para os dois sistemas de cultivo, foi na ordem de $0,05 \mathrm{MJ} \mathrm{m}^{-2} \mathrm{dia}^{-1}$. O sombreamento promovido pelo cultivo Leste-Oeste influenciou significativamente no fluxo de calor no solo, nas estações de final de verão, outono e início do inverno.

A utilização do modelo de análise e exclusão de intervalos em que o método de Razão de Bowen falha, melhora a qualidade dos dados. Aproximadamente $48 \%$ dos intervalos amostrados apresentaram algum tipo de erro, e desses, mais de 90\% dos casos aconteceram durante o período da noite.

A máxima evapotranspiração, 5,81 mm, ocorreu no verão, para o cultivo NorteSul e a mínima, 1,96 mm, ocorreu no inverno, para o cultivo Leste-Oeste.

Os sistemas de plantio diferenciaram a evapotranspiração do maracujazeiro nas estações de verão e inverno quando a análise não contemplou os intervalos inconsistentes. 


\section{DETERMINAÇÃO DA ÁREA FOLIAR DO MARACUJAZEIRO AMARELO POR MÉTODOS NÃO-DESTRUTIVOS}

\section{Resumo}

A área foliar das culturas é um parâmetro fitométrico importante e amplamente utilizado nas mais variadas áreas dos estudos agronômicos. No entanto, a sua obtenção é extremamente trabalhosa, principalmente em plantas que apresentam um elevado número de folhas. Desta maneira, objetivou-se correlacionar variáveis fitométricas (comprimento, largura e número de folhas), com medidas de área foliar de maracujazeiro amarelo, variedade IAC 275, obtida em medidor de precisão, assim como, avaliar o efeito da direção das linhas de cultivo no desenvolvimento foliar. Para isso, foram conduzidos 2 experimentos no Departamento de Engenharia Rural da Escola Superior de Agricultura “Luiz de Queiroz” USP. O experimento 1, foi aplicado no período de formação de mudas, com plantas apresentando folhas completas, cultivadas em ambiente protegido. O experimento 2 foi conduzido em condições de campo para duas diferentes orientações de plantio, com plantas apresentando folhas incompletas trilobadas. As medidas consideradas padrão foram obtidas em um medidor de área foliar (LI 3100, Li Cor). Todas as variáveis avaliadas (comprimento, largura ou número de folhas) apresentaram uma forte relação com a área foliar medida no LAI-3100. O modelo que utiliza o número total das folhas estimou a área foliar total com erro inferior a 2\% em relação aos valores medidos no LI-3100. A estimativa da área foliar das plantas cultivadas no sentido Norte-Sul pelo modelo "Dose de Resposta Logística (DRL)” foi 1,0 e 7,6 \% inferior àquelas cultivadas em linhas com direção Leste-Oeste, para as variáveis de tempo e graus-dia, respectivamente.

\section{Summary}

The leaf area is an important parameter used in agronomics studies. However, its acquisition is both extremely laborious and expensive, mainly in plants that present a large 
number of leaves. The aim of this work was to correlate easy variable fit metrics (length, width and leaf number) with the passion fruit leaf area for variety IAC 275, as well as, to evaluate the effect of the direction of plant row on foliar development. For this, two experiments were carried at the Department of Agricultural Engineering "Luiz de Queiroz" - USP. The first experiment was carried out during the period of seedling in plants that had a complete and simple leaves under greenhouse conditions. The second was carried out with plants that had an incomplete simple trilobed leaves planted in two different row directions under environmental conditions. The standard leaf area were measured by a leaf area meter ( LI 3100, Li Cor). All fit metrics variables evaluated (length, width or leaf number) had a strong correlation with the leaf area measured in the LAI-3100. The model that uses the total number of leaves for estimating the leaf area had an error lower at $2 \%$. The estimative of leaf area by "Logistic Dose Response (LDR)" showed that the plants in a row direction North-South were 1.0 and $7.9 \%$ lower than those planted in East-West for time and degree-days parameters, respectively.

\subsection{Introdução}

A área foliar é uma importante variável de crescimento e desenvolvimento, sendo bastante utilizada em estudos agronômicos. Como a fotossíntese total da planta é proporcional a área foliar exposta à radiação, sua determinação permite melhor

entendimento da interação da cultura com a energia disponível ao meio. À medida que a planta vai crescendo, há necessidade de uma maior captação de energia, aumentando a quantidade de folhas, consequentemente, aumenta-se sua área foliar total. Com isso, cresce a assimilação de $\mathrm{CO}_{2}$, aumento na evapotranspiração e conseqüentemente o acúmulo de matéria seca.

Com o objetivo de minimizar as dificuldades para obtenção da área foliar de determinadas espécies, alguns autores propuseram a utilização da área de projeção da copa a fim representar a área foliar total de plantas com folhas delgadas ou com formas irregulares (Smith, 1991; Bolstad \& Gower, 1990). 
Outros definiram o índice de área foliar (IAF), sendo a máxima projeção da área foliar por unidade de área do terreno. Assim, a área foliar também pode ser expressa em forma de índice (IAF), adimensional autores (Myneni et al., 1997).

Porém, seu emprego pode gerar informações duvidosas quando a área do terreno ocupada pela planta, se não for informada na investigação.

Na determinação da área foliar $(A f)$, os métodos são classificados em direto e indireto. Os métodos diretos são considerados os mais precisos (Chen et al., 1997), porém, são demorados, trabalhosos e destrutivos, entretanto, indispensáveis para validação dos métodos indiretos. Assim, as técnicas diretas podem ser consideradas importantes como métodos de calibração (Jonckheere et al., 2004). A área foliar pode ser avaliada diretamente utilizando métodos de amostragem destrutivos, porém, em muitos casos é necessário preservar a planta, valendo-se apenas dos métodos não destrutivos.

O maracujazeiro é um exemplo de plantas que apresentam heterofilia, um caráter ligado ao genótipo da planta e, portanto, hereditário, normalmente insensível à influência do meio, como nas espécies que possuem formas diferentes de folhas quando juvenil e adulta (Ferri et al., 1981). Este fenômeno dificulta a utilização de alguns métodos isolados de estimativa de $(A f)$. Alguns métodos indiretos utilizando o comprimento e largura da folha foram aplicados em várias culturas, como exemplo, manga (Mangifera indica L.) (Soule \& Malcolm, 1970), cacau (Theobroma cacau L.) (Reynolds, 1971), guava (Psidium guajava L.) (Kobayashi, 1988), citros (Citrus aurantium L.) (Ramkhelawan et al., 1990) e maracujá (Passiflora edulis Deg) (Turner et al., 1996).

Desta maneira, o objetivo deste trabalho foi o de avaliar métodos indiretos, que utilizam variáveis de fácil medida, para estimar a área foliar de plantas de maracujazeiro amarelo (Passiflora edulis Sims f. flavicarpa Deg.).

\subsection{Material e Métodos}

Devido a ocorrência de heterofilia em plantas de maracujazeiro (Figura 1), foram conduzidos 2 experimentos para avaliar o desenvolvimento da área foliar. O experimento 1 , foi conduzido durante o período de formação de mudas com plantas apresentando folhas 
simples completas, cultivadas em ambiente protegido (Figura 1A). O experimento 2, com plantas apresentando folhas simples incompletas trilobadas (Figura 1A), foi conduzido em condições de campo. No experimento 2, em duas parcelas experimentais, avaliou-se também o efeito da direção das linhas de cultivo no desenvolvimento do maracujazeiro. A pesquisa foi realizada na área experimental do Departamento Engenharia Rural da Escola Superior de Agricultura “Luiz de Queiroz” - ESALQ/USP (Piracicaba-SP), em Nitossolo vermelho segundo o sistema brasileiro de classificação de solos (EMBRAPA, 1999). O local, com latitude $-22^{\circ} 43^{\prime} 33^{\prime}$ ', longitude $47^{\circ} 38^{\prime} 0^{\prime \prime}$ e altitude de $576 \mathrm{~m}$, possui clima do tipo Cwa segundo a classificação climática de Köppen, sendo, subtropical úmido com estiagem no inverno, temperatura média anual de $21,1^{\circ} \mathrm{C}$ e precipitação média anual de aproximadamente $1250 \mathrm{~mm}$. O experimento 1, iniciou-se em 18/07/2003 com plantio de sementes de maracujazeiro (Passiflora edulis Sims f. flavicarpa Deg), cv. IAC 275, em sacos de polietileno preto $(14 \times 28 \mathrm{~cm})$, preenchidos com substrato composto por solo local e esterco bovino peneirado na proporção de $1: 1$.
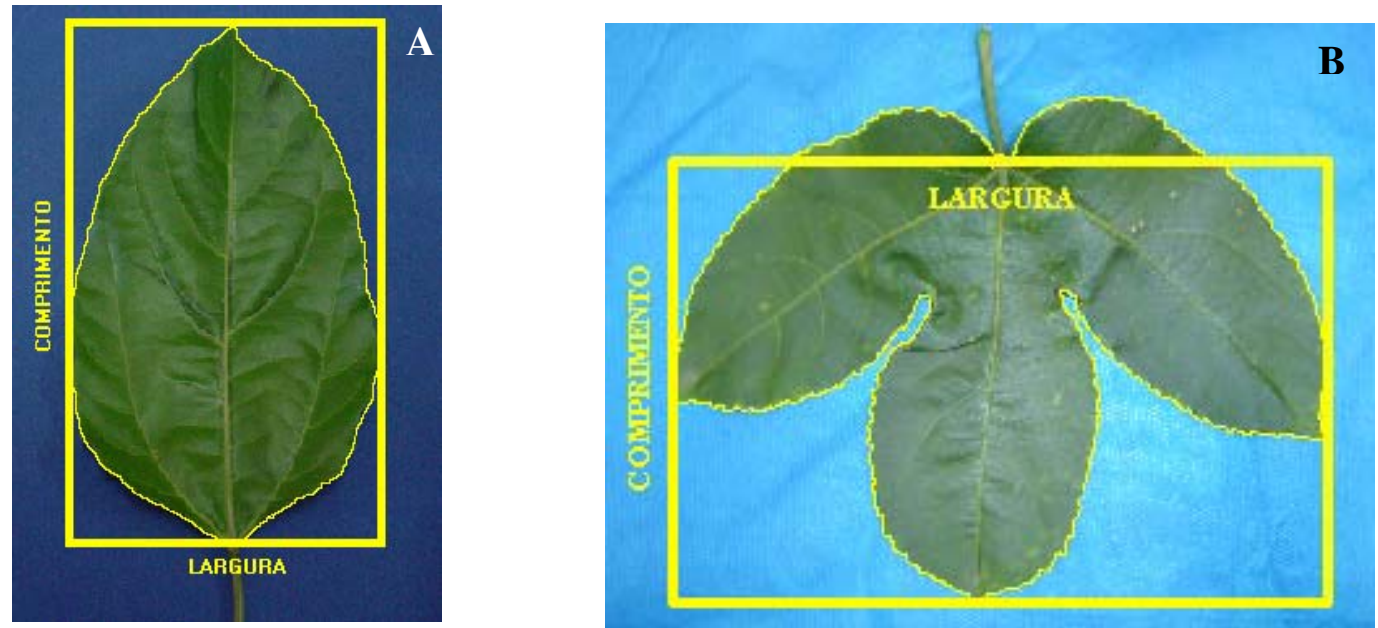

Figura 1 - Heterofilia em folhas de maracujazeiro (Passiflora edulis Sims f. flavicarpa Deg.). a) folha simples completa e b) folha simples incompleta trilobada

Foram semeadas duas sementes em cada um dos 500 sacos médio $(10 \times 15 \mathrm{~cm})$ para mudas. Em 15/10/2003, aos 73 dias após a germinação (DAG) foram amostradas aleatoriamente 20 plantas, destacadas todas as folhas e medidas com régua o comprimento 
da nervura principal e a largura de cada folha, em seguida, sua área foliar foi determinada com medidor padrão (LI-3100* da Li-Cor, Lincoln, Nebraska, USA).

O experimento de campo (experimento 2) era composto por duas parcelas. Para isto, foram transplantadas as mudas restantes do experimento 1 , em 25/10/2003, aos 83 DAG. A parcela 1 possuía 155 plantas distribuídas em 15 linhas de plantio orientadas no sentido Norte-Sul. Para a parcela 2, com 102 plantas distribuídas em 11 linhas, com orientação no sentido Leste-Oeste (Figura 2). Nas duas parcelas, todas as plantas foram tutoradas em espaldeira vertical com um único fio de arame (AWG 12) na altura de 1,8 m, fixado no topo dos mourões espaçados em $4 \times 4 \mathrm{~m}$. O espaçamento utilizado entre plantas também foi de $4 \times 4 \mathrm{~m}$. A área total do experimento 2 era de 0,51 ha, irrigada por microaspersores de vazão $40 \mathrm{~L} \mathrm{~h}^{-1}$ sempre que o potencial da água no solo de $-20 \mathrm{kPa}$ era atingido (valor médio de 4 tensiômetros instalados a 0,1 m de profundidade).

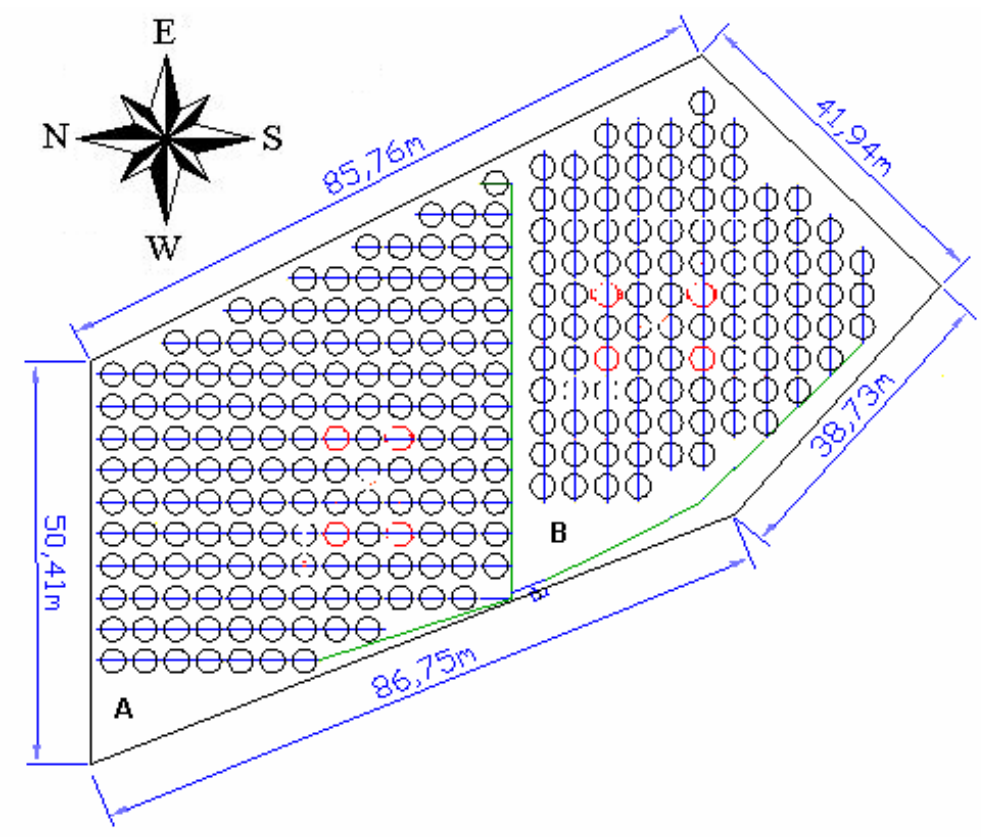

Figura 2 - Esquema de campo do experimento 2 com duas parcelas definidas pela orientação das linhas de cultivo; A) linhas no sentido Norte-Sul e B) LesteOeste

\footnotetext{
*Referências à marca registrada não constituem endosso por parte dos autores
} 
Para avaliar o desenvolvimento das plantas nas direções de plantio, foram escolhidas 2 plantas, em cada direção, e quantificada a área foliar quinzenalmente até 258 DAG.

Foram feitas relações dos parâmetros fitométricos (comprimento, largura e número de folhas), variáveis físicas (dias após o plantio e graus-dia acumulados) com área foliar. Para o cálculo de graus-dia acumulados, utilizou-se a metodologia sugerida por Ometto (1981), considerando-se o intervalo de temperaturas ótimas entre 7 e $30{ }^{\circ} \mathrm{C}$ (Utsonomya, 1992).

\subsection{Resultados e Discussão}

Para o experimento 1 , as relações empíricas de estimativas da área foliar ( $A f$, em $\mathrm{cm}^{2}$ ) para plantas de maracujazeiro no estádio inicial, ou seja, com folhas simples completas, apresentaram alta correlação com as variáveis de fator de forma (Ff) (comprimento $x$ largura da folha), comprimento $(C f)$ e largura da folha ( $L f$ ) (Figura 3). A área foliar total das plantas foi facilmente estimada de acordo com as Equações 1, 2 e 3, para as variáveis independentes de $F f$, $C f$ e $L f$, respectivamente.

$$
\begin{aligned}
& A f=\sum_{1}^{n} 0,694 F f \\
& A f=\sum_{1}^{n} 0,308 C f^{2,113} \\
& A f=\sum_{1}^{n} 1,107 L f^{2,033}
\end{aligned}
$$

em que,

$A f$ - Área foliar total da planta $\left(\mathrm{cm}^{2}\right)$;

$\mathrm{Ff}$ - Fator de forma $\left(\mathrm{cm}^{2}\right)$;

$C f$ - Comprimento da folha medido da nervura principal até o ápice (cm);

Lf - Largura máxima da folha (cm). 

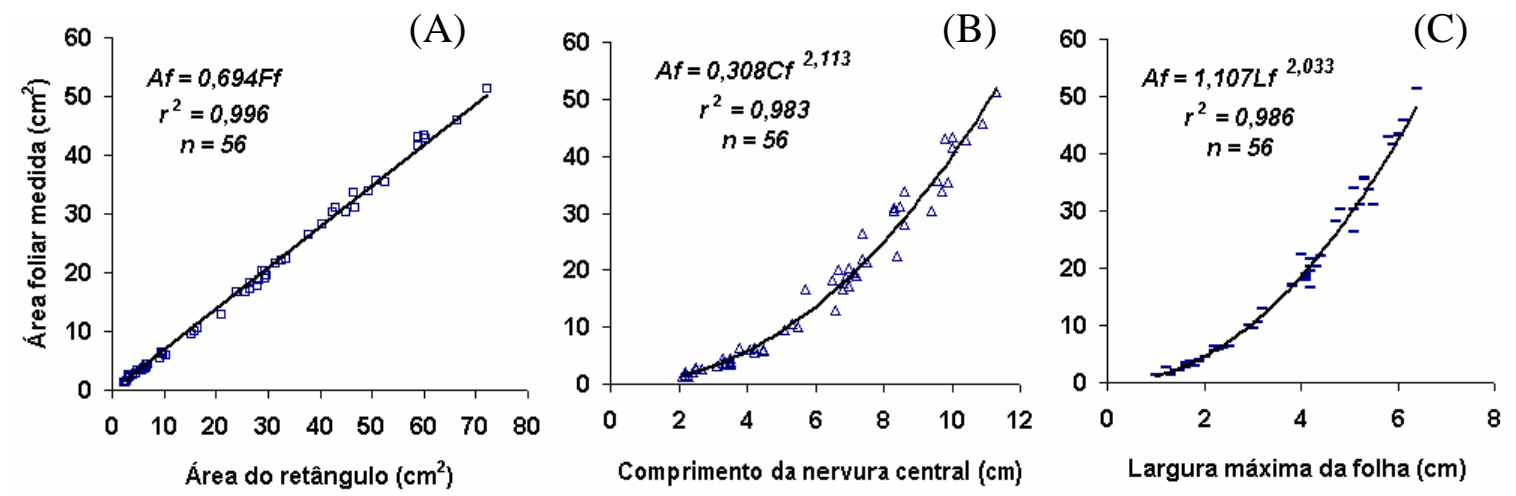

Figura 3 - Relações de área foliar por modelos linear (A) e potência (B e C), com as áreas medidas em 56 folhas simples completas de maracujazeiro, utilizando variáveis de: $F f$ - fator de forma (A), $C f$ - comprimento da nervura central da folha (B) e $L f$ largura máxima da folha (C)

A precisão dos modelos foi testada comparando os valores estimados com os valores medidos no LAI-3100 (Figura 4). As estimativas realizadas com Ff e Cf (Equações 1 e 2) sobrestimaram a área total medida, enquanto que $L f$ (Equação 3) subestimou. Observando a Tabela 1, nota-se que o modelo que utiliza o Ff (Equação 1) como variável independente, mesmo apresentando o melhor $r^{2}$, forneceu o maior valor de desvio percentual (1,71\%), em relação aos modelos que contemplaram o comprimento ou a largura da folha isoladamente. Turner et al. (1996) utilizaram em vários experimentos a função Af $=0,0027 C f^{2,1563}\left(r^{2}=0,97 ; n=24\right)$, para folhas de maracujazeiro com comprimentos $(C f$, de 9 a $130 \mathrm{~mm}$, e $A f$, em $\mathrm{cm}^{2}$ ). Os coeficientes encontrados para o modelo que utiliza o $C f$ neste estudo foram bem semelhantes àqueles encontrados pelos autores acima, apresentando menor percentagem de desvio (0,23\%) em relação aos outros modelos testados (Tabela 1). A vantagem de optar pelo modelo que contempla apenas o comprimento, é utilizar apenas uma variável além de que, a determinação do comprimento da nervura central da folha é mais confiável que a medida de largura da folha, a qual poderá associar-se erros de calibração visual do operador. 
Tabela 1. Comparação da exatidão dos modelos de regressão na estimativa da área foliar de plantas de maracujazeiro em formação de mudas com folhas simples completas ( $\mathrm{n}=56$ folhas)

\begin{tabular}{|c|c|c|c|c|}
\hline Equação & $\begin{array}{c}\text { Coeficiente de } \\
\text { determinação }\left(r^{2}\right)\end{array}$ & $\begin{array}{l}\text { Total de área } \\
\text { medida }\left(\mathrm{cm}^{2}\right)\end{array}$ & $\begin{array}{c}\text { Total de área } \\
\text { estimada }\left(\mathrm{cm}^{2}\right)\end{array}$ & Desvio (\%)* \\
\hline 1 & 0,996 & 964,74 & 981,28 & 1,71 \\
\hline 2 & 0,983 & 964,74 & 966,92 & 0,23 \\
\hline 3 & 0,986 & 964,74 & 956,34 & $-0,87$ \\
\hline
\end{tabular}

*Percentagem de desvio = (área total estimada-área total medida $)$ x 100/área total medida.
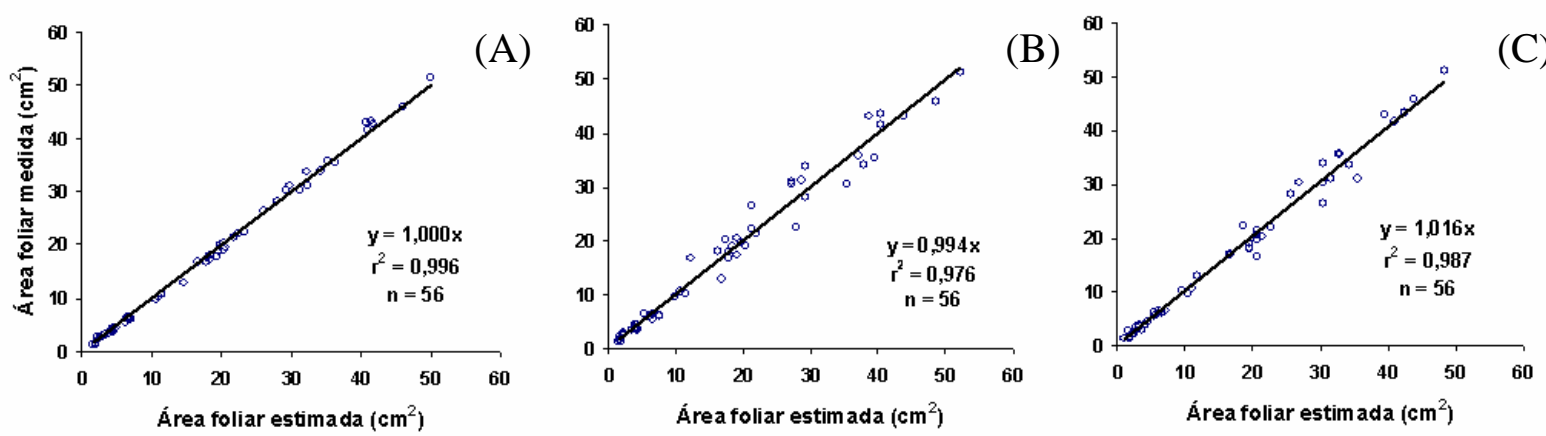

Figura 4 - Relação entre valores medidos em 56 folhas simples completas de maracujazeiro e valores estimados pelos modelos de regressão linear, para o $F f$ - fator de forma (A); potência, para o $C f$ - comprimento da nervura central da folha (B) e $L f$ largura máxima da folha $(\mathrm{C})$

No segundo experimento, em plantas de maracujazeiro com folhas após heterofilia, as relações empíricas de estimativas da $A f\left(\mathrm{~cm}^{2}\right)$ apresentaram alta correlação com as variáveis $F f$, $C f$ e $L f$ (Figura 5). A área foliar total das plantas foi estimada de acordo com as Equações 4, 5 e 6, para as variáveis independentes de $F f$, $C f$ e $L f$, respectivamente. 
(A)

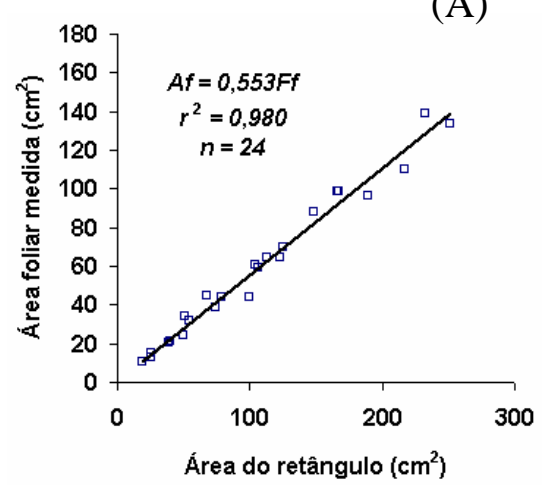

(B)

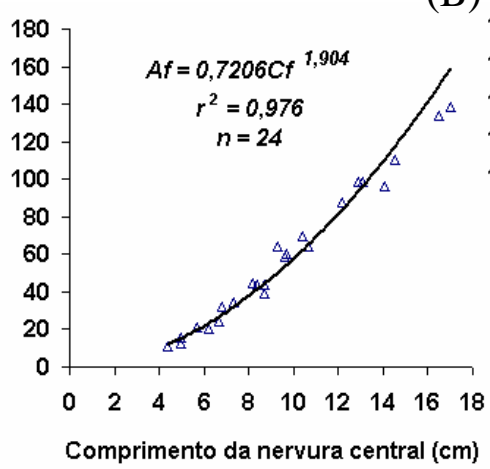

(C)

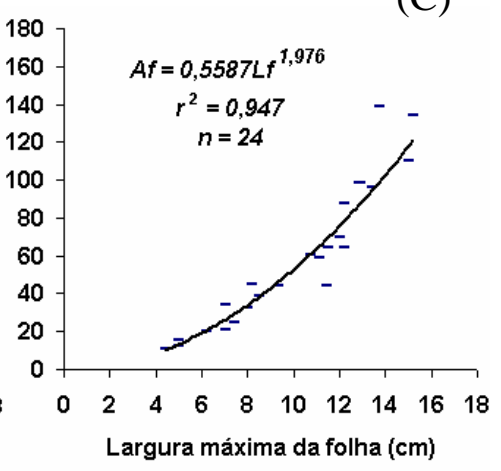

Figura 5 - Relações da área foliar por 3 modelos com a área medida de 24 folhas simples incompletas trilobadas de maracujazeiro utilizando as variáveis $F f$ - fator de forma (A), $C f$ - comprimento da nervura central da folha (B) e $L f$ - largura máxima da folha $(\mathrm{C})$

$$
\begin{aligned}
& A f=\sum_{1}^{n} 0,553 F f \\
& A f=\sum_{1}^{n} 0,7206 C f^{1,904} \\
& A f=\sum_{1}^{n} 0,5587 L f^{1,976}
\end{aligned}
$$

em que,

Af - Área foliar total da planta $\left(\mathrm{cm}^{2}\right)$;

Ff - Fator de forma $\left(\mathrm{cm}^{2}\right)$;

$C f$ - Comprimento da folha medido da nervura principal até o ápice (mm);

Lf - Largura máxima da folha (mm).

As estimativas realizadas com $F f$ e $L f$ (Equações 4 e 6) subestimaram a área foliar total medida, enquanto que o $C f$ (Equação 5) sobreestimou. Na Tabela 2, nota-se que o modelo que utiliza o $F f$ como variável independente, apresentou o melhor coeficiente de determinação, gerando um menor desvio percentual (-0,41 \%) em relação aos modelos que 
contemplaram o comprimento (1,17\%) ou a largura (2,2 \%) da folha isoladamente. Apesar do $C f$ (Equação 5) apresentar menor precisão que o Ff (Equação 4), sugere-se optar por este modelo, pelas mesmas razões discutidas acima para estimativa de $A f$ em plantas com folhas simples completas.

Tabela 2. Comparação da exatidão dos modelos de regressão na estimativa da área foliar de plantas de maracujazeiro em formação de mudas com folhas simples incompletas trilobadas $(\mathrm{n}=24$ folhas)

\begin{tabular}{ccccc}
\hline Equação & $\begin{array}{c}\text { Coeficiente de } \\
\text { determinação }\left(r^{2}\right)\end{array}$ & $\begin{array}{r}\text { Total de área } \\
\text { medida }\left(\mathrm{cm}^{2}\right)\end{array}$ & $\begin{array}{c}\text { Total de área } \\
\text { estimada }\left(\mathrm{cm}^{2}\right)\end{array}$ & \begin{tabular}{c} 
Desvio (\%)* \\
\hline 4
\end{tabular} $0^{0,980}$ \\
5 & 0,976 & 1425,16 & 1419,25 & $-0,41$ \\
6 & 0,947 & 1425,16 & 1441,80 & $+1,17$ \\
& & 1393,77 & $-2,20$
\end{tabular}

*Percentagem de desvio = (área total estimada-área total medida) x 100/área total medida.
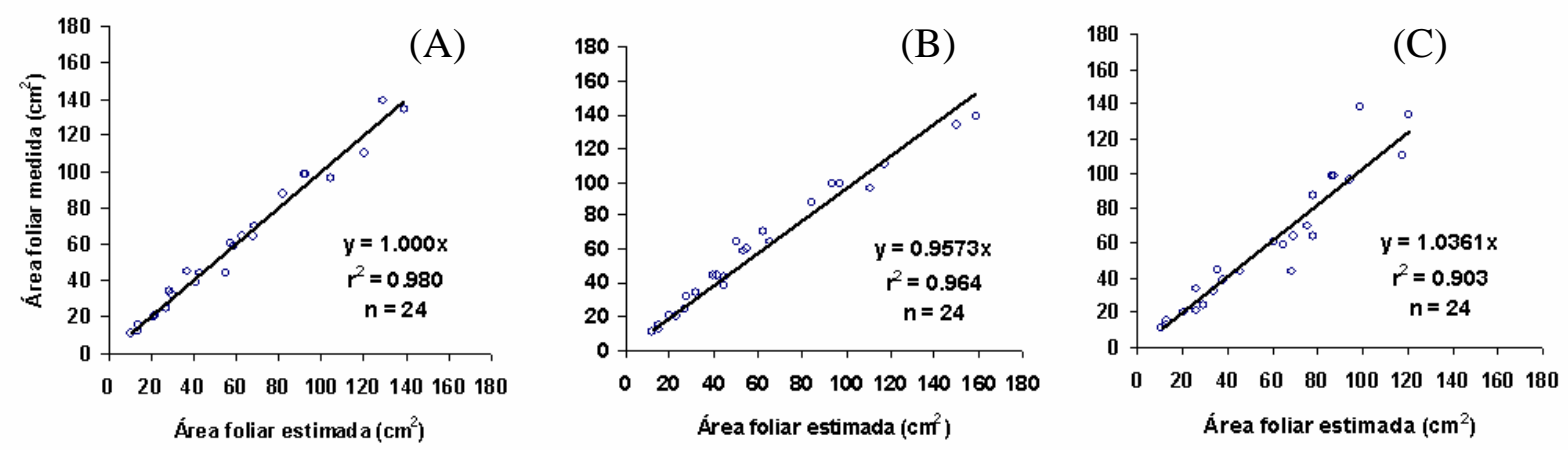

Figura 6 - Relação entre valores medidos em 24 folhas simples incompletas trilobadas de maracujazeiro e valores estimados pelos modelos de regressão linear, para o Fffator de forma (A); potência, para o Cf- comprimento da nervura central da folha (B) e $L f$ - largura máxima da folha (C)

Ainda para plantas de maracujazeiro com folhas simples incompletas trilobadas, foi avaliado um outro método que relacionava o número de folhas $(N f)$ com $A f$. A Equação 7 apresenta a relação entre os valores medidos de $A f$, em $\mathrm{m}^{2}$ e o número de folhas coletadas 
de 39 plantas escolhidas aleatoriamente. O modelo, representado na Figura 7, mostrou forte correlação para a variável independente $N f$ - número de folhas $\left(r^{2}=0,98 ; \mathrm{n}=39\right)$, que estimou a área foliar total da planta a partir do produto do valor de área média de uma folha pelo número total de folhas.

$$
A f=0,0069 N f
$$

em que,

Af - Área foliar total da planta $\left(\mathrm{m}^{2}\right)$;

$N f$ - Número total de folhas da planta.
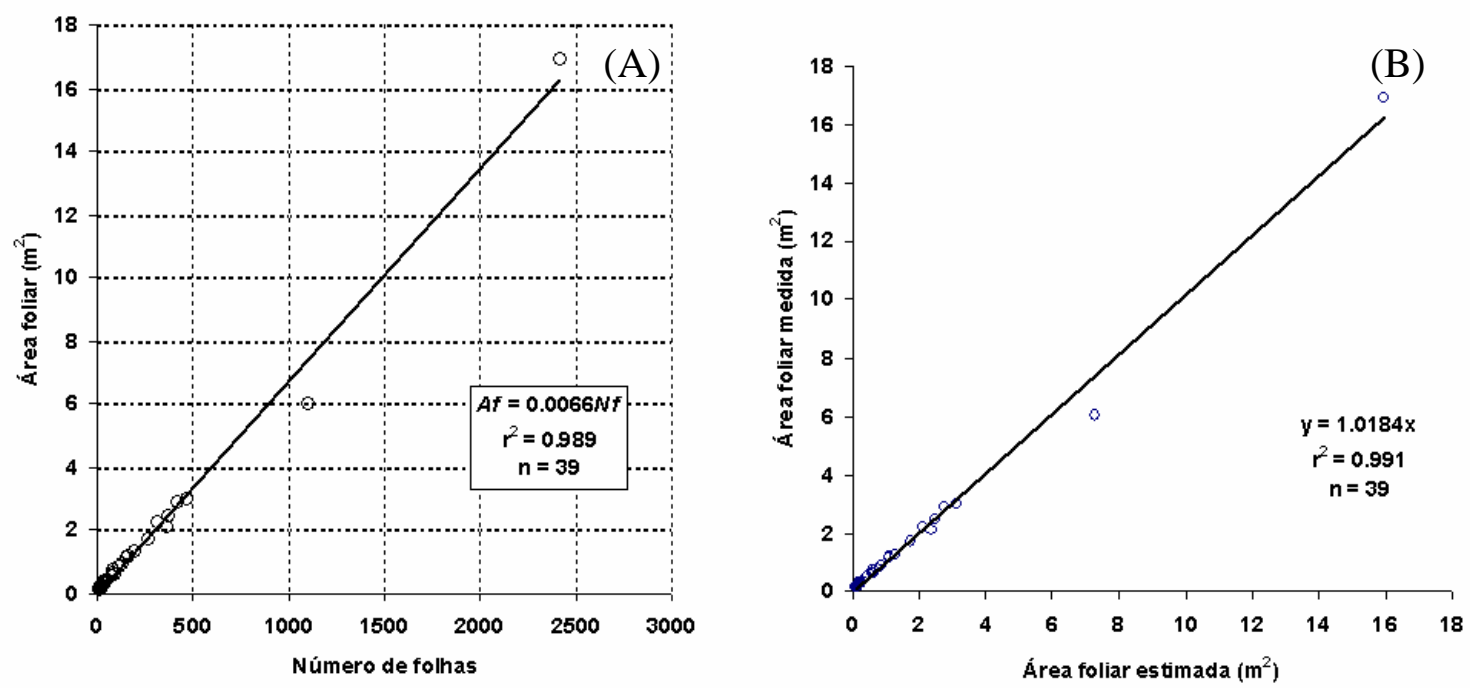

Figura 7 - Relação entre a área foliar medida em 39 plantas de maracujazeiro com folhas simples incompletas trilobadas, e a variável número de folhas (A). Comparação entre os valores medidos e os estimados (B)

Este modelo apresentou em média desvios percentuais de 15,81\% e subestimativa na ordem de $1,53 \%$, ou seja, $0,77 \mathrm{~m}^{2}$ para um total amostrado de 50,54 $\mathrm{m}^{2}$ (n $=7428$ folhas). A vantagem deste método é a sua praticidade em relação aos outros métodos indiretos (fator de forma, comprimento e largura).

A evolução diária de $A f$ para as duas parcelas do experimento, em função do tempo (DAP), e dos graus-dia acumulados resultou em funções de resposta de dose logística $(D R L)$. Estes modelos estão representados nas Figuras 8 e 10. 


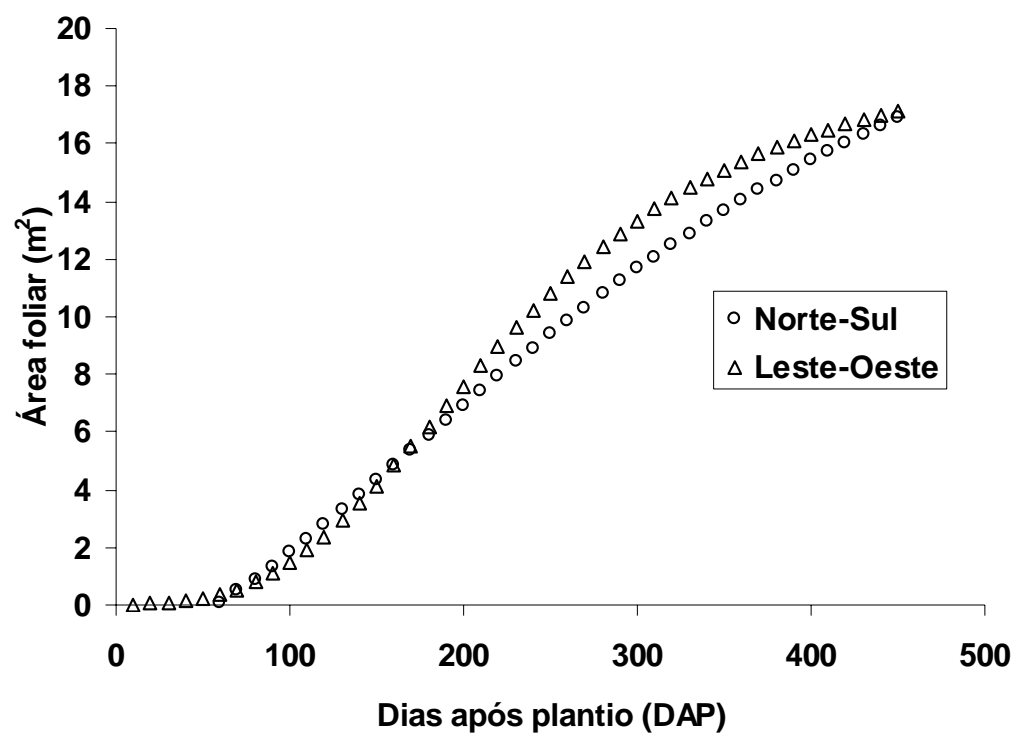

Figura 8 - Estimativa da evolução diária da área foliar média de plantas de maracujazeiro com linhas de plantio cultivadas nas direções Norte-Sul e Leste-Oeste

Para a função do tempo (DAP), o modelo obteve coeficientes de determinação $\left(r^{2}\right)$ de 0,988 e 0,991, para plantas de maracujazeiro com linhas cultivadas nas direções NorteSul (Equação 8) e Leste-Oeste (Equação 9), respectivamente. Para função de graus-dia acumulados (GDA), obteve-se coeficientes de determinação $\left(r^{2}\right)$ de 0,993 e 0,985, para plantas de maracujazeiro com linhas de plantio cultivadas nas direções Norte-Sul (Equação 10) e Leste-Oeste (Equação 11), respectivamente.

$$
\begin{aligned}
& A f=-1,28745+\frac{30,941275}{\left[1+\left(\frac{D A P}{364,24236}\right)^{-1,6997629}\right]} \quad r^{2}=0,998 \\
& A f=0,02784+\frac{19,50433}{\left[1+\left(\frac{D A P}{232,83305}\right)^{-2,9918353}\right]} \quad r^{2}=0,991
\end{aligned}
$$

em que, 
$A f$ - Área foliar do DAP $\left(\mathrm{cm}^{2}\right)$;

$D A P$ - Número do dia após plantio da cultura no campo.
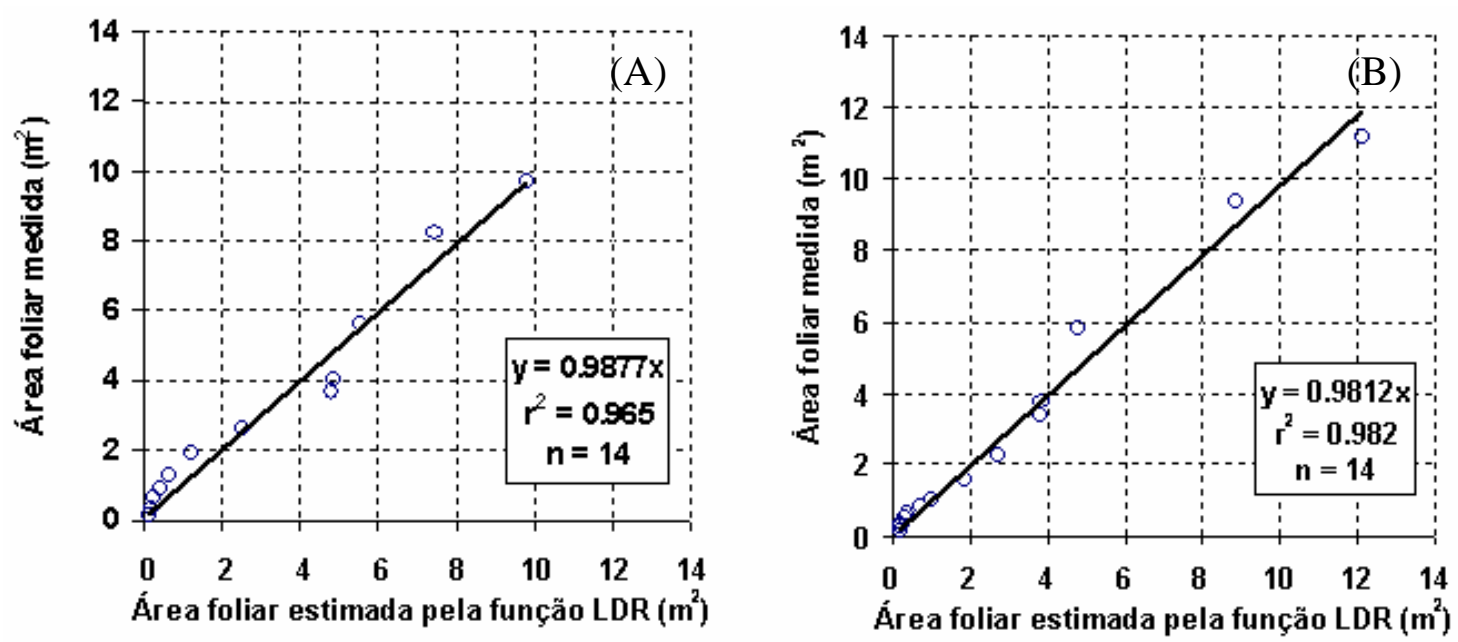

Figura 9 - Relações entre os valores de área foliar medidos e os estimados por meio das Equações 8 e 9 geradas pelo programa gráfico, para cada orientação de plantio (A) Norte-Sul; (B) Leste-Oeste

Na Figura 9, observa-se as relações entre os valores de área foliar medidos e os estimados por meio das funções de dose de resposta logística $(D R L)$, geradas pelo programa, para cada orientação de plantio (Equações 8 e 9). Para o maracujazeiro cultivado em linhas com orientação Norte-Sul, o modelo $D R L$ forneceu para valores estimados de $A f$, desvios percentuais na ordem de $0,31 \%$. Para o cultivo com linhas no sentido Leste-Oeste este percentual foi menor $(0,11 \%)$.

De acordo com os métodos não destrutivos de estimativa de $A f$ avaliados neste trabalho, ajustados no modelo $D R L$ com variável de entrada o número de dias após plantio, as plantas de maracujazeiro até os $450 D A P$, e orientadas no sentido Norte-Sul apresentaram aproximadamente 16,93 $\mathrm{m}^{2}$ de área foliar (valor médio de 2 plantas), ou seja, $1 \%$ inferior a área foliar das plantas cultivadas em linhas com direção Leste-Oeste ( $A f=$ $\left.17,15 \mathrm{~m}^{2}\right)$. 


$$
A f=0,06+\frac{22,78624}{\left[1+\left(\frac{G D A}{4163,242}\right)^{-2,406676}\right]} \quad r^{2}=0,993
$$

$$
A f=0,0017+\frac{19,725741}{\left[1+\left(\frac{G D A}{3550.8016}\right)^{-3,2384889}\right]} \mathrm{r}^{2}=0,985
$$

em que,

Af - Área foliar $\left(\mathrm{m}^{2}\right)$;

GDA - Constante térmica acumulada.

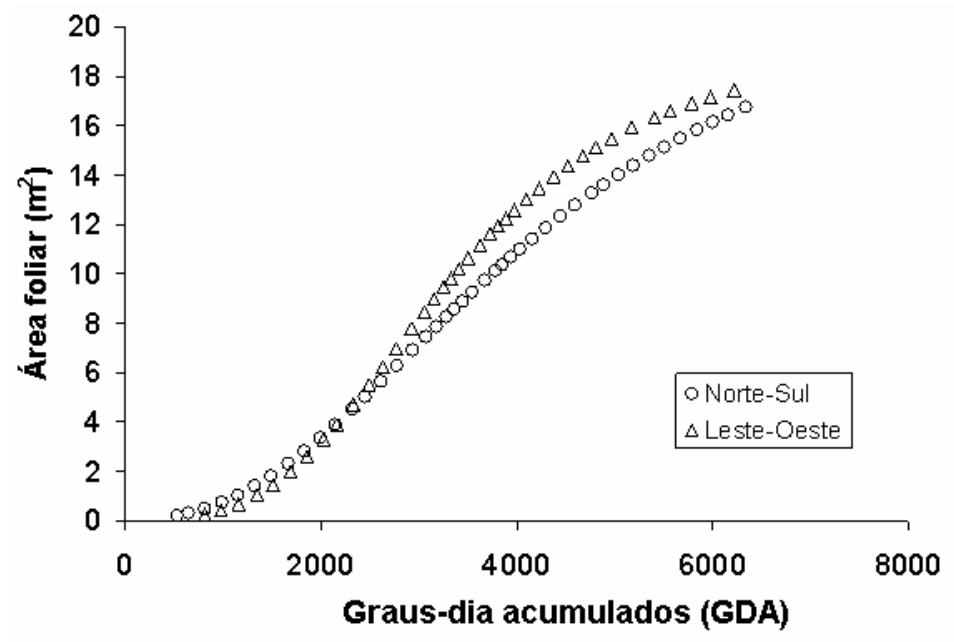

Figura 10 - Estimativa da área foliar de plantas de maracujazeiro em função do graus-dia acumulados (GDA), com linhas de plantio nas direções Norte-Sul e LesteOeste

A Figura 11 nos mostra as relações entre os valores de área foliar medidos e os estimados por meio das funções de resposta de dose logística $(L D R)$, geradas pelo programa de computação gráfica, para cada orientação de plantio (Equações 10 e 11). 

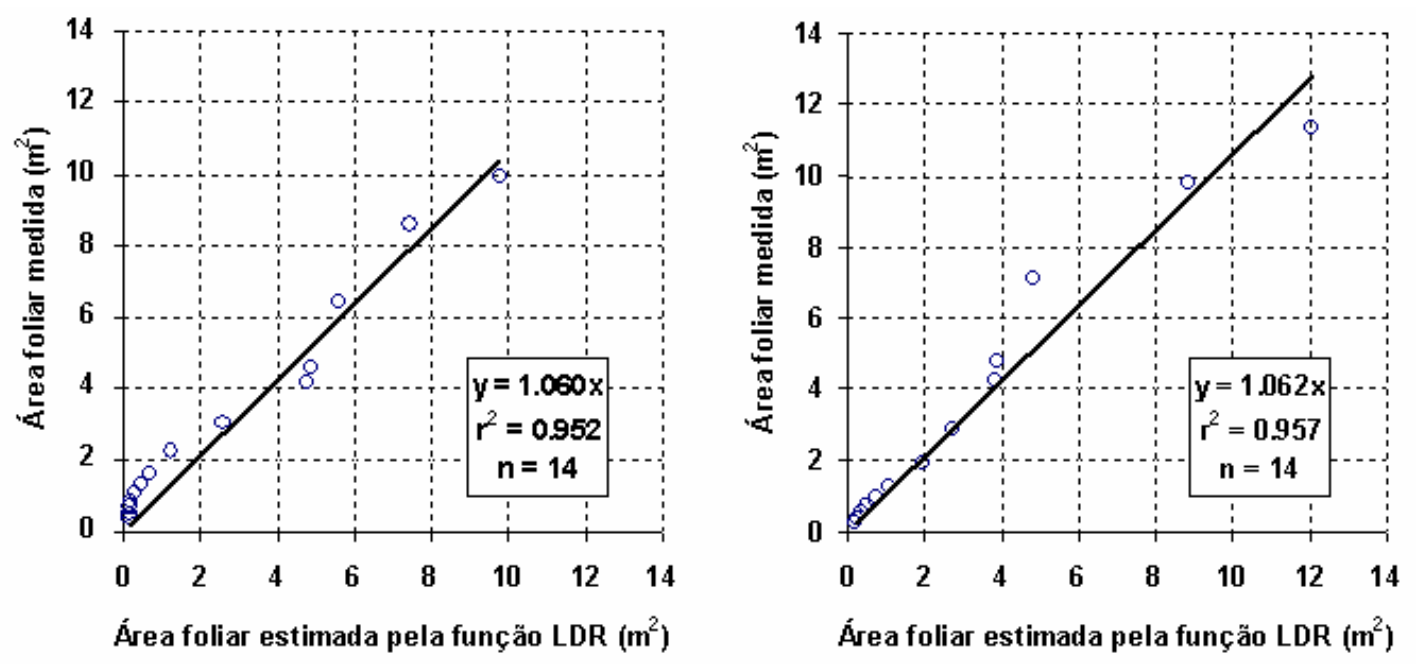

Figura 11 - Relações entre os valores de área foliar medidos e os estimados por meio das Equações 10 e 11 geradas pelo programa gráfico, para cada orientação de plantio (a) Norte-Sul; (b) Leste-Oeste

Para o maracujazeiro cultivado em linhas com orientação Norte-Sul, o modelo $D R L$ forneceu para valores estimados de $A f$, desvios percentuais na ordem de 1,21\%. Para o cultivo com linhas no sentido Leste-Oeste este percentual foi menor, 0,26 \%.

De acordo com os métodos não destrutivos de estimativa de $A f$ avaliados neste trabalho, ajustados pelo modelo $D R L$ com variável de entrada os graus-dia acumulados (GDA), para plantas de maracujazeiro cultivadas até os $450 D A P$, e orientadas no sentido Norte-Sul, a área foliar total foi 16,13 $\mathrm{m}^{2}$ (valor médio de 2 plantas), ou seja, 7,8 \% inferior a área foliar das plantas cultivadas em linhas com direção Leste-Oeste $\left(A f=17,49 \mathrm{~m}^{2}\right)$.

A variável graus-dia acumulados (GDA) para estimativa de área foliar de maracujazeiros pelo modelo de dose de resposta logística, permite aplicação em outras regiões climáticas. Isso é possível porque o modelo engloba a soma térmica necessária para completar cada estádio de crescimento da cultura, diferindo da variável dia após o plantio (DAP), específica para a situação experimental. 


\subsection{Conclusões}

Todas as variáveis fitométricas avaliadas (fator de forma, comprimento ou largura da folha) apresentaram uma forte relação com a área medida.

O polimorfismo foliar apresentado pelo maracujazeiro não interferiu nas determinações de áreas foliares por meio da variável comprimento da folha, que se tornaram mais práticas.

O modelo que utiliza o número total das folhas estimou a área foliar total com erro inferior a $2 \%$ em relação aos valores medidos.

As orientações de plantio influenciaram no desenvolvimento foliar do maracujazeiro, sendo a área foliar das plantas cultivadas no sentido Leste-Oeste superiores às cultivadas em linhas com direção Norte-Sul.

A área foliar do maracujazeiro pode ser estimada em função da idade da planta e graus-dia acumulados. 


\section{CONSTRUÇÃO E CALIBRAÇÃO DE LISÍMETROS DE PESAGEM COM CÉLULAS DE CARGA HIDRÁULICA}

\section{Resumo}

O conhecimento da evapotranspiração dos cultivos é essencial no manejo da irrigação. Lisímetros são equipamentos padrões, de alta precisão importantes na determinação da evapotranspiração e consequentemente geração de coeficientes de cultivos $(K c)$, no entanto, estes equipamentos são caros. Buscando-se alternativas para diminuição dos custos construtivos, desenvolveram-se vários tipos de lisímetros, porém, os de pesagem são os que fornecem resultados mais consistentes. As células de carga eletrônica permitem o monitoramento instantâneo e registro automático em sistemas de aquisição (datalogger), porém, seu custo é bastante elevado. Em teste de laboratório e campo, objetivou-se avaliar o desempenho das células de carga hidráulica, através de calibrações simultâneas em comparação as células eletrônicas, e por fim, verificar o funcionamento de um transdutor de pressão eletrônico acoplado às células para automação dos dados. O arranjo das células de carga em forma de triangulo eqüilátero promoveu boa estabilidade e distribuição equilibrada de forças. O estabelecimento do volume ideal de fluído proporcionou calibrações lineares e consequentemente, melhor desempenho dos lisímetros. As correlações entre os valores de variação de massa e os observados no piezômetro, célula eletrônica e transdutor de pressão apresentaram alto coeficiente de determinação.

\section{Summary}

The knowledge of crop evapotranspiration is essential for irrigation scheduling. Lysimeters are standard equipments, with high precision and important for determine evapotranspiration and crop coefficients $(K c)$, however, are expensive. Looking for a lowcost alternative, it was developed lysimeters of many types but the weighing have showed 
results more consistently. The electronic load cells allow monitoring real-time measurements and stored data in automatic system (data logger) however, its cost is very high. The performance of a hydraulic load cells and a pressure transductor were evaluated by calibration with electronic load cells in laboratory and field conditions. The triangular design of load cells promoted a good stability and distribution of forces. The establishment of an ideal fluid volume leaded a liner calibrations and better performances. Relationships between mass variation and values read in piezometer, electronic load cells and pressure transductor showed high determination coefficient.

\subsection{Introdução}

O conhecimento da evapotranspiração dos cultivos é essencial no manejo da irrigação. A evapotranspiração da cultura pode ser determinada por métodos diretos ou indiretos. Os métodos diretos baseiam-se no balanço hídrico em volume de solo conhecido, e os indiretos em parâmetros climáticos. Dentre os métodos de medida direta, os lisímetros se destacam por oferecer o maior nível de precisão na determinação da evapotranspiração (Pereira et al. 1997). Silva et al. (1999), comparando lisímetros de drenagem, lençol freático constante e pesagem, concluíram que lisímetros de pesagem apresentam-se mais precisos e consistentes na determinação da evapotranspiração. Aboukhaled (1982) define lisímetros como equipamentos padrão, de alta precisão e importantes na determinação da evapotranspiração dos cultivos e conseqüentemente seus coeficientes $(K c)$, no entanto, são equipamentos relativamente caros, empregados apenas em experimentação científica.

As células de carga eletrônica permitem o monitoramento instantâneo e o registro automático em sistemas de aquisição (datalogger), porém, seu custo é bastante elevado (Silva et al., 2003). Os lisímetros de pesagem hidráulica foram descritos por Hanks e Shawcroft (1965), Tanner (1967), Dylla \& Cox (1973), e McFarland et al. (1983). No Brasil, o primeiro equipamento deste tipo foi construído e descrito por Rodrigues (1987), para estudos de evapotranspiração de grama (ETo), na cidade de Parnamirim, Pernambuco.

Em teste de laboratório e campo, objetivou-se avaliar a desempenho das células de carga hidráulica, através de calibrações simultâneas em comparação as células eletrônicas, 
e por fim, verificar o funcionamento de um transdutor de pressão eletrônico acoplado às células para automação dos dados.

\subsection{Material e Métodos}

\subsubsection{Construção do lisímetro e teste de laboratório}

A primeira parte do trabalho foi desenvolvida no Laboratório de Hidráulica e a segunda, na estação experimental de irrigação na Fazenda Areão do Departamento de

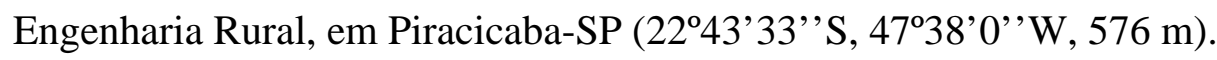

Para o teste de laboratório construiu-se um lisímetro utilizando-se uma caixa de polietileno de $0,5 \mathrm{~m}^{3}$, preenchida com brita e água para atingir massa de $1 \mathrm{t}$, simulando a condição de $0,5 \mathrm{~m}^{3}$ de solo úmido. Três células de carga hidráulica foram construídas com segmentos de mangueiras de butil-propileno interligadas hidraulicamente por microtubos de polietileno transparente. Outras três células de carga eletrônica com capacidade máxima de $980 \mathrm{~kg}$ cada, foram sobrepostas às anteriores (Figura 1).
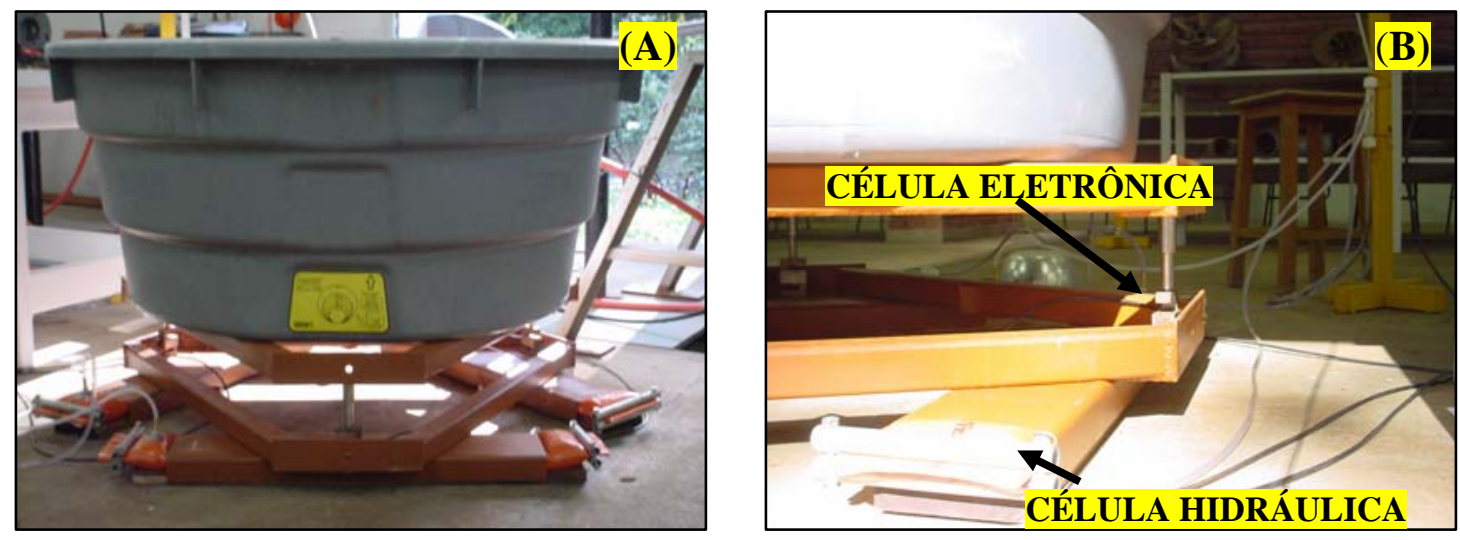

Figura 1 - Células de carga eletrônica (padrão) e hidráulica. Caixa de polietileno sobre estrados e células de carga (A), detalhe das células de carga (B)

Um procedimento importante na construção dos lisímetros foi o estabelecimento do volume ideal de água utilizado no preenchimento das células de carga hidráulica, recomendado por Silva et al., (2003). Nos ensaios de calibração realizados no laboratório, 
determinou-se o volume de água ideal com auxílio de um registro de saída tripla. (Figura 2).

As três células foram totalmente preenchidas com água até a sua capacidade total, aproximadamente 7 litros cada, em seguida, foram interligadas hidraulicamente por meio de um adaptador construído com 0,15 m de tubo PVC de 12,7 mm (1/2”), dois caps e cinco conectores de metal com bico para mangueira de 6,35 x 19,05 mm (BM 1/4 x NPT 3/8”) (Figura 7). A saída marcada com '4' foi conectada à um piezômetro e as marcadas com '1, 2 e 3' a um transdutor de pressão com sensibilidade de 0,1 mV (modelo MPX 5010 Motorola, Inc.). Através de uma das saídas do registro ' $\mathrm{C}$ ' foram liberados volumes iguais de água (50 ml), sendo a diferença de cada leitura lidas no piezômetro, em mm, e correlacionadas com valores acumulados de volume retirado.

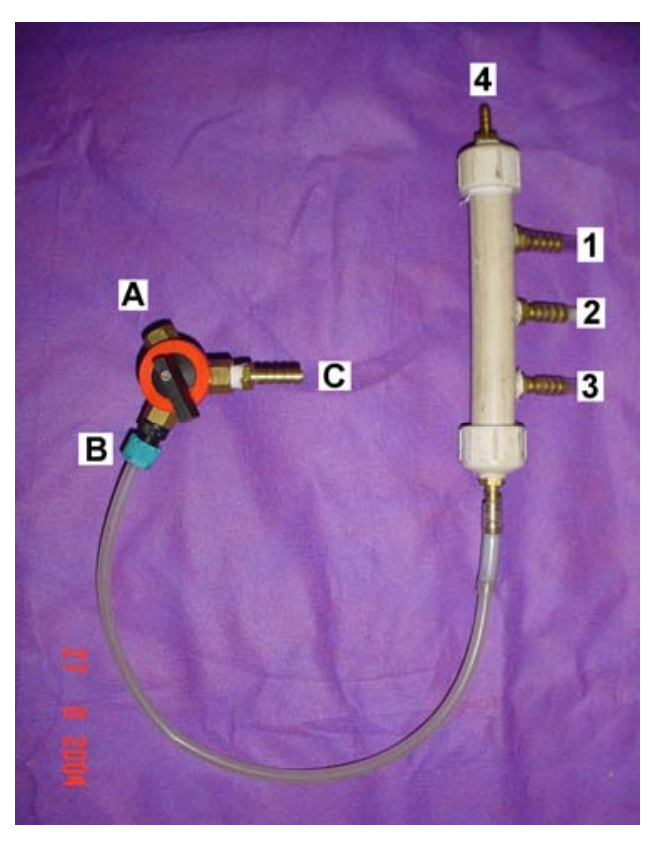

Figura 2 - Dispositivos utilizados no processo de enchimento das células de carga hidráulica

Um sistema automático de coletas de dados (CR21X, Campbell Scientific, Logan, Utah, EUA) foi utilizado para realizar os registros das células de carga eletrônicas e do transdutor de pressão. 
Realizou-se calibração por adição e retirada de 21 pesos de 2,1 kg cada, totalizando um incremento total de $41,1 \mathrm{~kg}$. Os pesos foram adicionados e retirados um a um, aguardando 2 minutos para estabilização das leituras.

\subsubsection{Construção dos lisímetros no campo}

Em campo, foram construídos 4 lisímetros de pesagem hidráulica, semelhante ao do teste anterior, com pequenas modificações (Figura 3A e 3B). Foram compostos pelas

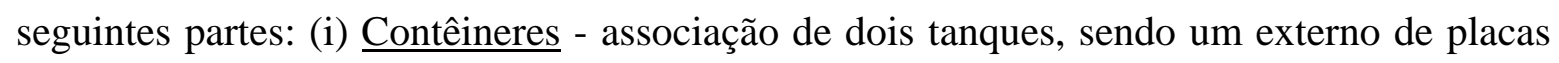
premoldadas e outro interno, de polietileno; (ii) Sistema hidráulico de pesagem - formado por três células de carga hidráulica, dispostas em forma de triangulo eqüilátero (ângulo de $120^{\circ}$ entre os lados) (iii) Sistema transmissor de pressão - conecções tipo bico e rosca, anéis de aço inox, tubo de polietileno transparente e adaptador de PVC. (iv) Sistema de leitura composto por um manômetro de "poço" com mercúrio e água (líquidos manométrico), escala milimétrica, conectores, microtubos de silicone e tubo capilar de vidro; e (v) Sistema

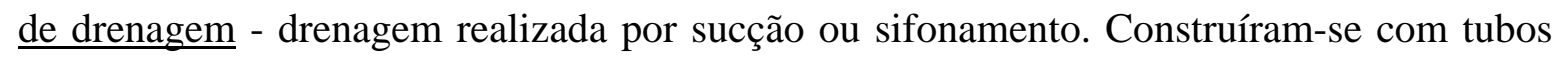
perfurados de PVC, cotovelos e um envelope de brita recoberta com bidim.

\section{(A)}

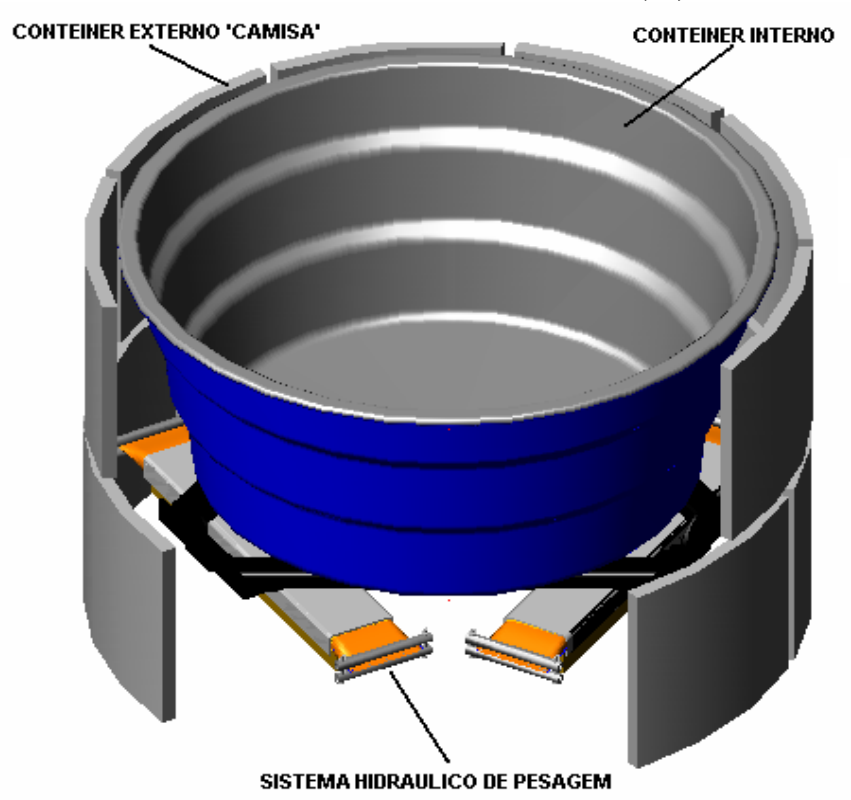

(B)

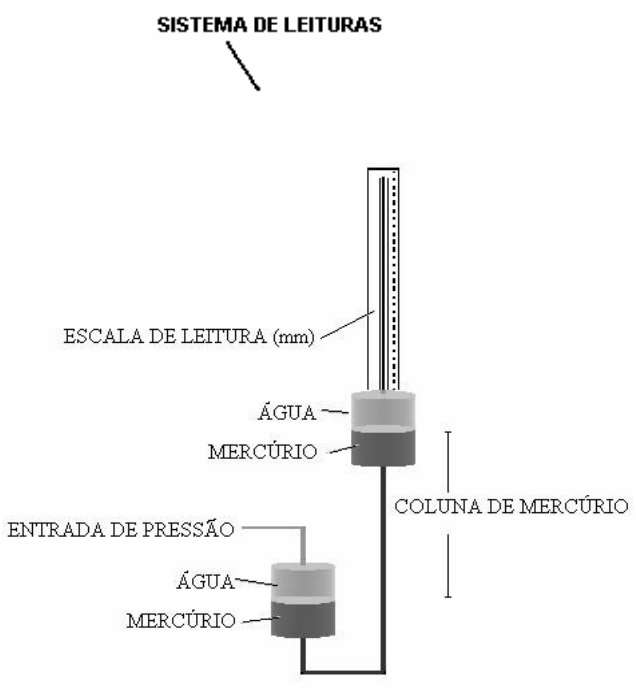

Figura 3 - Principais componentes de um lisímetro de pesagem hidráulica (A) com detalhe para o sistema de leituras (B) 
Dois contêineres de diâmetros diferentes foram arranjados um dentro do outro, sendo o externo, denominado de "camisa" e o outro, denominado contêiner interno. Para contêiner interno foi utilizado uma caixa d'água de polietileno, com diâmetro de 1,15 m e capacidade de 500 L. Optou-se pela escolha deste material por ser leve, resistente a intempéries e de baixo custo. Como desvantagem o material oferece pouca resistência mecânica, e por essa razão, foi necessário apoiá-la em um suporte metálico, denominado de estrado, para melhor distribuição das forças. A “camisa” (Figura 4B) foi estabelecida com placas pré-moldadas, confeccionadas de acordo com a técnica utilizada na construção de cisternas (Bernat et al., 1993). As dimensões do molde utilizado na confecção das placas foram de 0,6 x 0,5 m e espessura de 0,03 m (Figura 4A). Cada "camisa" era composta por 16 placas pré-moldadas montadas em duas fileiras de oito placas. A espessura das placas (3 $\mathrm{cm}$ ), forneceu uma área de borda de $0,11 \mathrm{~m}^{2}$, ou seja, $10 \%$ da área útil do lisímetro, sendo esta considerada pequena, o suficiente para não ter problemas de emissão de radiação de ondas ao contrário de um material com grande área de borda que causa efeitos na evapotranspiração (Aboukhaled et al., 1982).
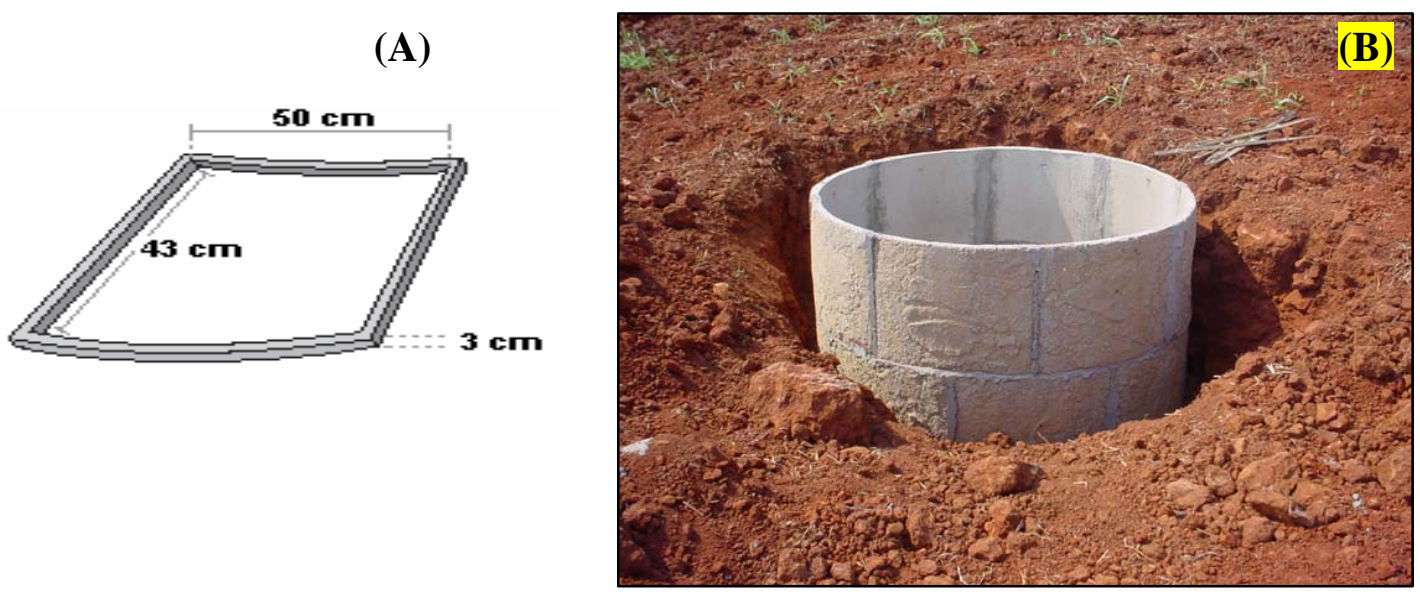

Figura 4 - Molde utilizado na fabricação de placas pré-moldadas (A) e montagen da "camisa” (B)

O estrado foi construído para suportar $800 \mathrm{~kg}$, feito com perfil de aço de secção quadrada com 50 x $50 \mathrm{~mm}$ e espessura de $5 \mathrm{~mm}$, cantoneiras de $75 \mathrm{~mm}$ de lado e espessura de 7,5 mm, disco em chapa de aço de 6,5 mm de espessura e 0,5 m de diâmetro (Figura 5). 
Foram fixados três segmentos de corrente com um metro de comprimento cada, elos de 6,5 $\mathrm{mm}$ de espessura, presas por meio de parafusos de aço de 50 x $8 \mathrm{~mm}$ nas extremidades (vértices) do estrado. Estas correntes servem para içar o lisímetro caso haja necessidade de manutenção ou substituição do sistema hidráulico de pesagem.

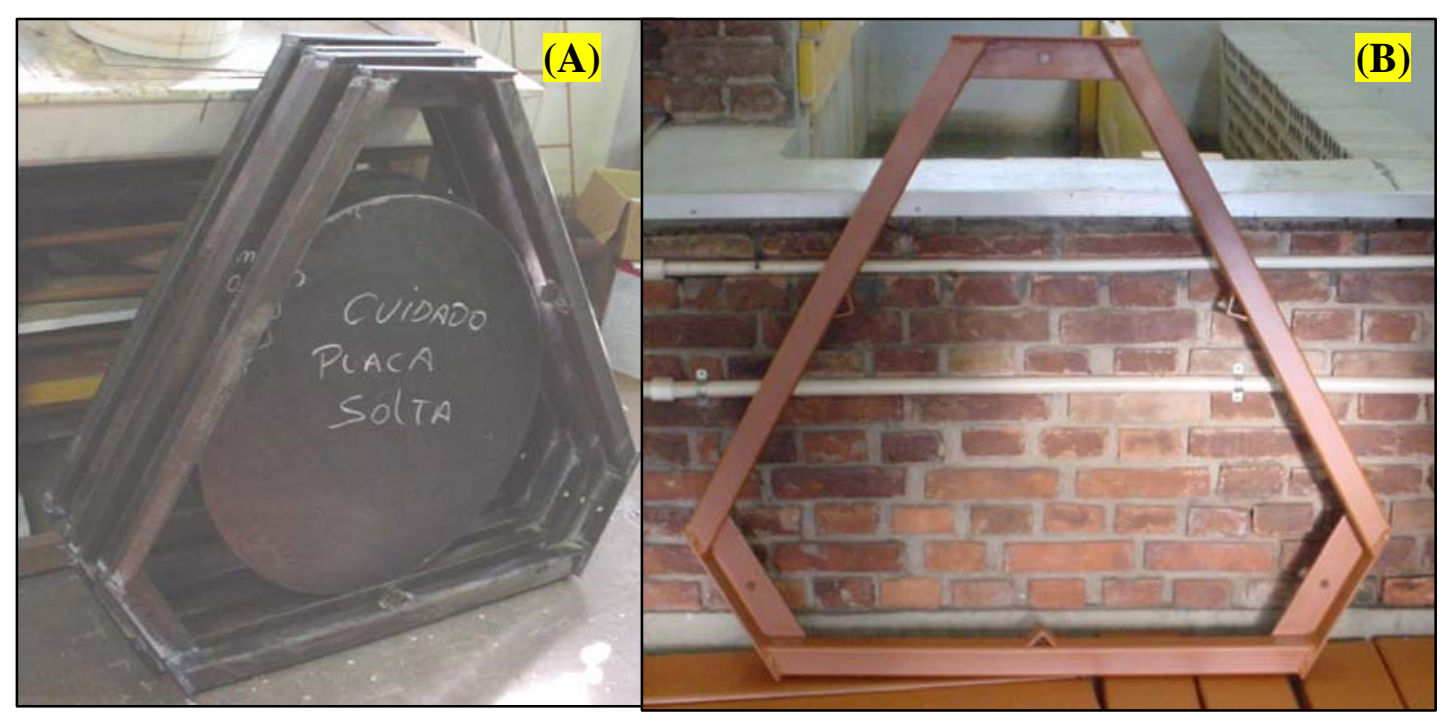

Figura 5 - Suporte metálico (estrado). Sem revestimento anti-ferrugem (A) e estrados prontos para serem montados (B)

O contêiner interno e o estrado de ferro ficavam apoiados em três células de carga hidráulica, cada uma feita com $1 \mathrm{~m}$ de mangueira de $254 \mathrm{~mm}$ de diâmetro, do tipo auto extinguível, fabricada com butil-propileno reforçado com tecido de nylon (Spiraflat SDRL (S) marca Goodyear 4") (Figura 6). As mangueiras tiveram suas extremidades vedadas por pressão, utilizando-se dois pares de tubos galvanizados com 0,2 $\mathrm{m}$ de comprimento, sendo um par por extremidade. Os tubos foram furados transversalmente para colocação de parafusos sextavado com 6,35 x 63,5 mm (1/4 x 2,5") (Figura 6B e 6C). Não houve necessidade de adicionar cola nas extremidades da mangueira, porque a vedação foi realizada apenas com a pressão exercida pelos tubos com parafusos. 


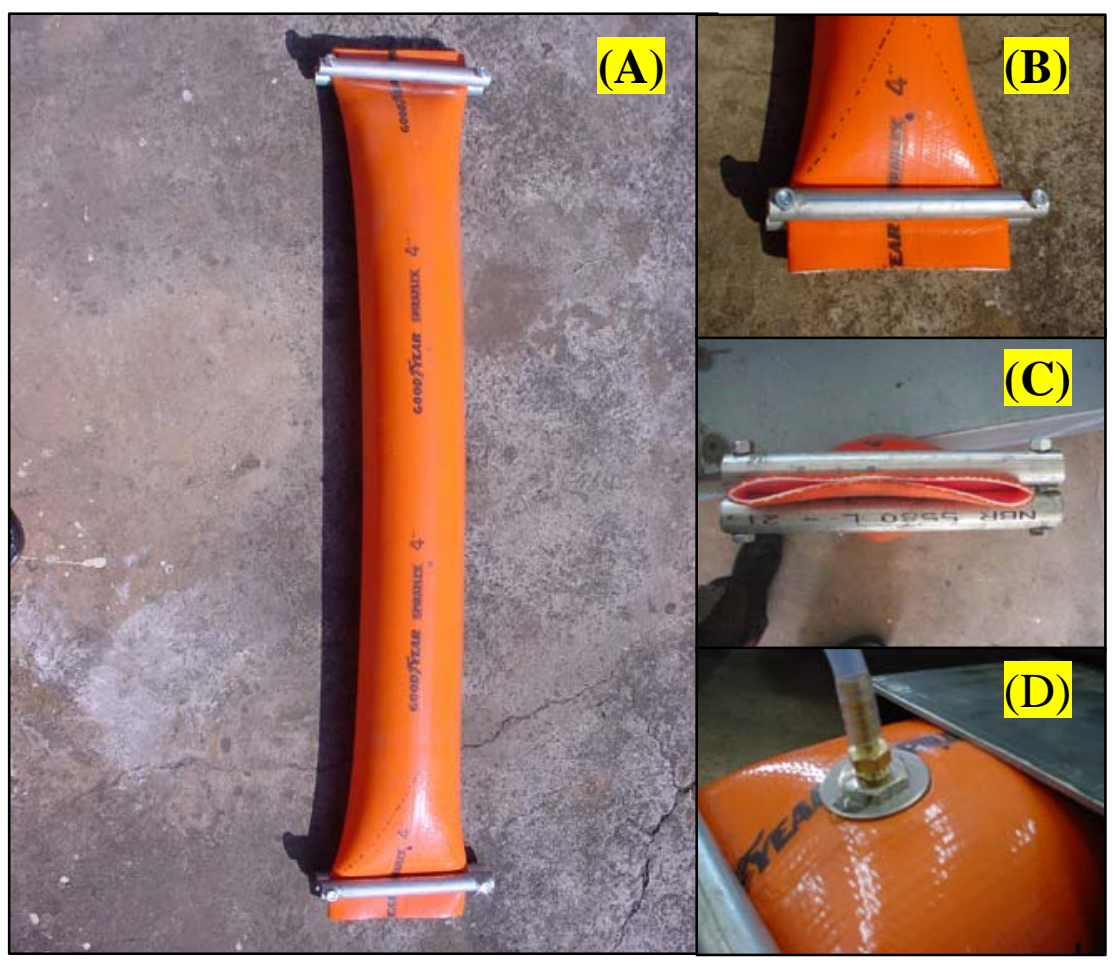

Figura 6 - Detalhes construtivos das células de carga hidráulica. Tubos aparafusados para vedação das extremidades da mangueira (A) e (B) e conector de saída de pressão (C)

Também em uma das extremidades da mangueira, a 0,1 m de distância, foi adaptado um conector para acoplamento do tubo flexível de polietileno transparente. Este conector de metal tipo para mangueira de 6,35 x 9,52 mm (BM 1/4" x NPT 3/8"), foi fixado em um orifício feito na mangueira. Neste procedimento utilizou-se cola a base de resina epóxi, duas arruelas e uma porca de 9,25 mm (3/8”), todas em aço inox para resistir à corrosão (Figura 6D).

Sobre cada célula de carga hidráulica foi colocado um perfil de aço no formato "U”, de $100 \mathrm{~mm}$ de largura, $50 \mathrm{~mm}$ de altura e $750 \mathrm{~mm}$ de comprimento (Figura 7B), para proporcionar distribuição uniforme do peso ao longo da célula. O perfil também servia para manter constante a área de contato entre célula de carga hidráulica e a base de apoio do lisímetro. 
Neste projeto foram construídas três bases de apoio de 0,75 x 0,15 x 0,2 m para cada lisímetro, utilizando dois blocos de concretos pré-moldados por base, totalizando seis por lisímetro. As dimensões de cada bloco foi de 0,15 x 0,25 x 0,2 m (Figura 7).

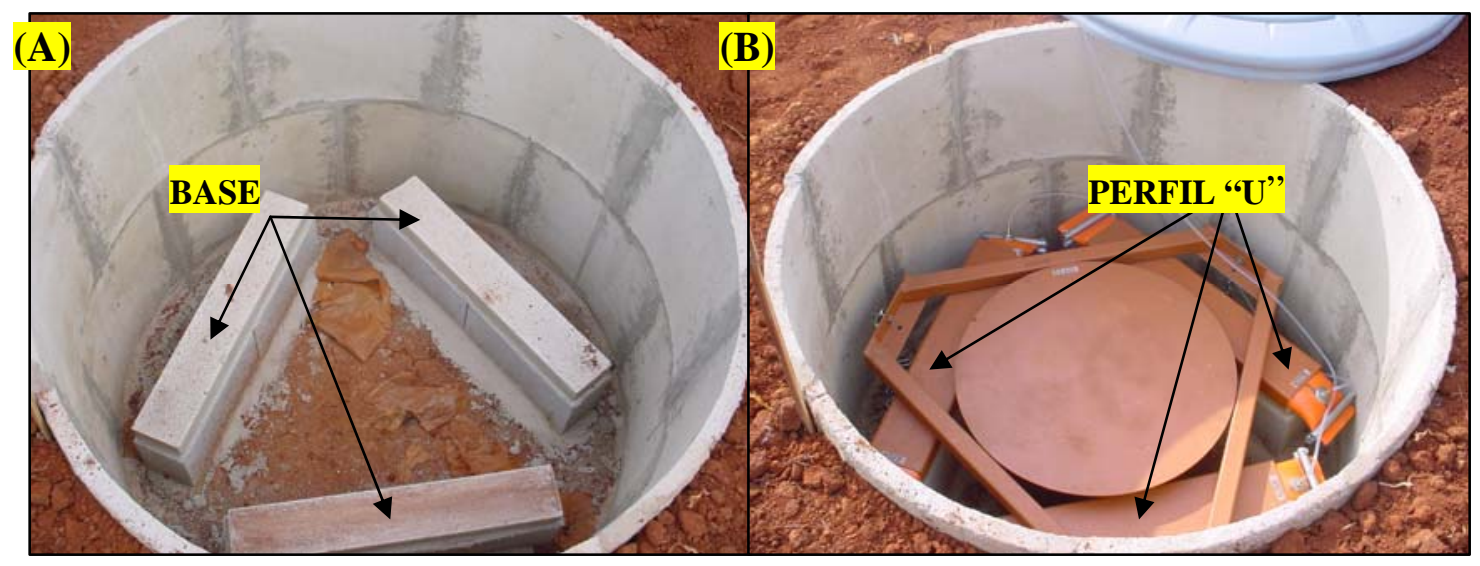

Figura 7 - Construção das bases de apoio e montagem do sistema de pesagem hidráulica

Uma fina camada de argamassa composta de uma parte de cimento para quatro de areia, foi espalhada no piso para fixação dos blocos pré-moldados e depois em seu topo para nivelamento. Após a construção e secagem das bases (três dias), procedeu-se a montagem do sistema de pesagem (Figura 7B). Antes desta etapa foi necessário preencher as células com volume adequado de água, estabelecido previamente no teste de laboratório. Para isso utilizou-se água destilada e fervida, mantida em repouso por 12 horas, para eliminar as bolhas de ar. Este procedimento se fez necessário, porque o ar possui maior compressibilidade que a água, que é praticamente incompressível nas condições de pressão de funcionamento do sistema. A presença de ar dentro das células, tubos de transmissão de pressão e sistema de leituras podem causar erros de medições.

O sistema de leituras mostrado na Figura 8, consiste em dois recipientes cilíndricos de vidro com $120 \mathrm{~mm}$ de comprimento e $30 \mathrm{~mm}$ de diâmetro interno, espessura de parede igual a $2 \mathrm{~mm}$ e suas extremidades fechadas com placas de nylon de $10 \mathrm{~mm}$ de espessura. A vedação foi estabelecida com auxílio de 2 anéis de borracha e 4 hastes com rosca de 3,5 mm de espessura e porcas. O fundo dos recipientes foram interligados por meio de um tubo de polietileno transparente de 33mm x $26 \mathrm{~mm}$. 


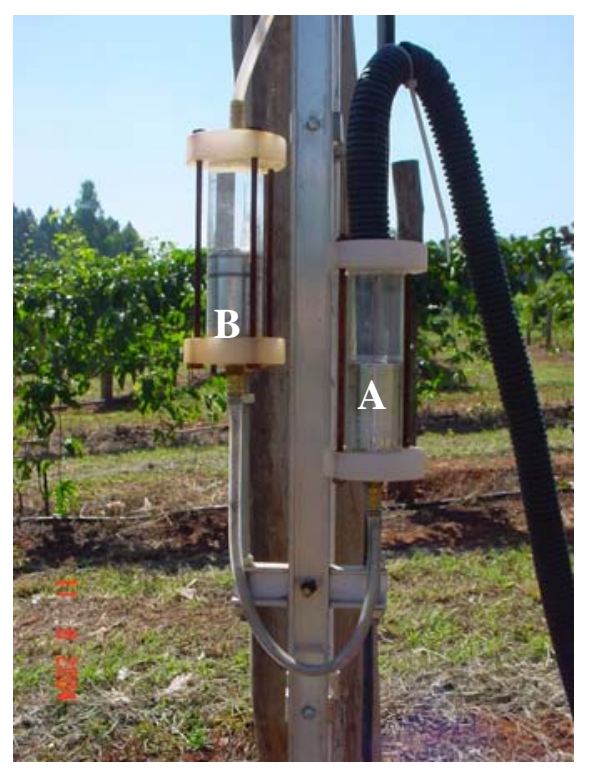

Figura 8 - Dispositivo utilizado para rebaixamento da cota de leitura no piezômetro

A parte superior do recipiente 'A' indicado na Figura 8 foi conectada ao adaptador de PVC (Figura 7), e este por sua vez, conectado as três células, enquanto que a parte superior do recipiente ' $\mathrm{B}$ ' foi conectado ao tubo de vidro (piezômetro) de $700 \mathrm{~mm}$ de comprimento e 4,8 mm de diâmetro. Os dois recipientes foram cheios até a metade com mercúrio, e o volume restante preenchido com água destilada, incluindo o tubo de vidro do manômetro preso à escala de leituras. Os recipientes foram montados em um suporte regulável que permitia variação de cota entre eles, e com isso estabelecer a pressão de equilíbrio entre a coluna de mercúrio e as células hidráulicas.

Para abrir as trincheiras foi utilizada uma escavadeira mecânica, entretanto, tomando-se o cuidado de separar cada camada de 0,2 $\mathrm{m}$ de solo, para que o perfil original pudesse ser reconstituído novamente no processo de enchimento do tanque interno. Depois de construídas as "camisas", bases de apoio, sistemas de pesagem e de leitura, conforme descrito anteriormente, realizou-se a colocação do tanque interno e montagem do sistema de drenagem. No sistema de drenagem, empregou-se tubos de PVC e cotovelo de $75 \mathrm{~mm}$ de diâmetro, cascalho com partículas de $10 \mathrm{~mm}$, aproximadamente, e tecido de bidim. $\mathrm{Na}$ Figura 9A, observa-se a disposição do sistema de drenagem dos tubos de PVC no interior do lisímetro, detalhando os tubos verticais acoplados nas extremidades do tubo horizontal. 
O tubo horizontal possuía vários crivos ao seu redor e foi parcialmente coberto com uma camada de 75 mm de cascalho, e em seguida pela manta de bidim (Figura 9B).

A reposição do solo dentro do tanque interno foi realizada de forma que reproduzisse o perfil original, mais próximo possível da condição de contorno. Para isto, após recolocação de cada camada (0,2 m), era adicionada água para facilitar a acomodação das partículas do solo e desta maneira, aproximando-se da sua densidade original. Os tubos verticais do sistema de drenagem foram utilizados para drenar o excesso de água adicionada no processo de recomposição dos horizontes. Realizou-se drenagem por sifonagem com auxílio de um tubo de polietileno de $10 \mathrm{~mm}$ de diâmetro. Um tubo de acesso de 0,2 m de diâmetro de 1,5 m de profundidade foi instalado próximo ao lisímetro para rebaixamento da cota de descarga do sifão abaixo do fundo do lisímetro.

Obtiveram-se coeficientes de calibração, em mm kg${ }^{-1}$, pela razão entre a variação de leitura no manômetro e a variação de massa no lisímetro.
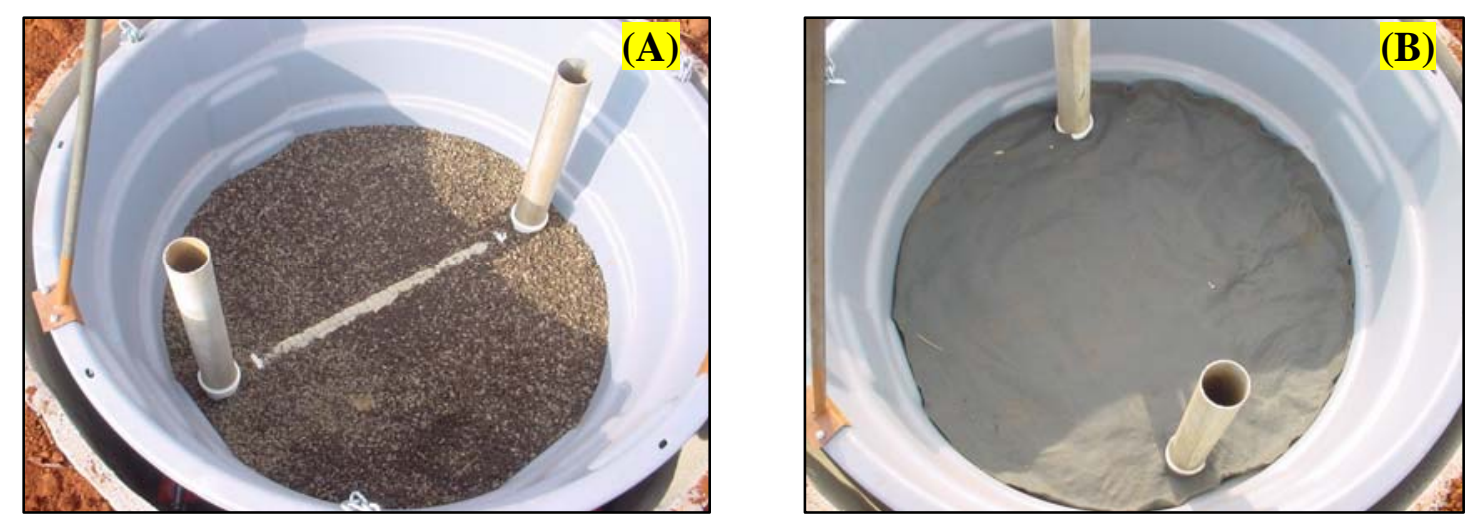

Figura 9 - Instalação do sistema de drenagem utilizado nos lisímetros de pesagem hidráulica

A calibração foi realizada pela adição de 20 pesos de 2,1 kg cada, totalizando uma variação de 39,9 kg. A capacidade total de água do solo do lisímetro (DTA) era de 38,7 mm, considerando a profundidade de 0,56 m. Portanto, para área de $1 \mathrm{~m}^{2}$, e considerando a densidade da água igual a 1, a variação de armazenamento é igual a 38,7 kg de água. Assim, a calibração realizada totalizando 39,9 kg, incluiu toda a faixa de variação de armazenamento de água efetiva para o volume de solo avaliado. 
No processo de calibração dos lisímetros os pesos foram adicionados um a um, aguardando o tempo de 2 minutos para estabilização, antes de efetuar cada leitura no piezômetro. Após todos os pesos serem adicionados, eles foram removidos sucessivamente e efetuado também as leituras do ciclo de descarregamento. As calibrações foram realizadas durante a noite para minimizar o efeito temperatura sobre o sistema de pesagem hidráulica.

\subsection{Resultados e Discussão}

\subsubsection{Volume ideal de água para as células de carga hidráulica}

Observa-se na Figura 10 que inicialmente as diferenças medidas no piezômetro para as extrações de $50 \mathrm{ml}$ água foram grandes, diminuindo à medida que a área de contato entre a mangueira e a base foi se tornando praticamente invariável com as extrações.

Resultados semelhantes foram obtidos por Silva et al., 2003. Os volumes foram removidos das três células interligadas hidraulicamente, onde juntas possuíam inicialmente um volume total de $17124 \mathrm{ml}$, e se retirou $5150 \mathrm{ml}$ acumulados no final do teste. A partir do conjunto de pontos obtidos foi possível correlaciona-los com os volumes acumulados e ajustá-los ao modelo polinomial de $2^{\mathrm{a}}$ ordem:

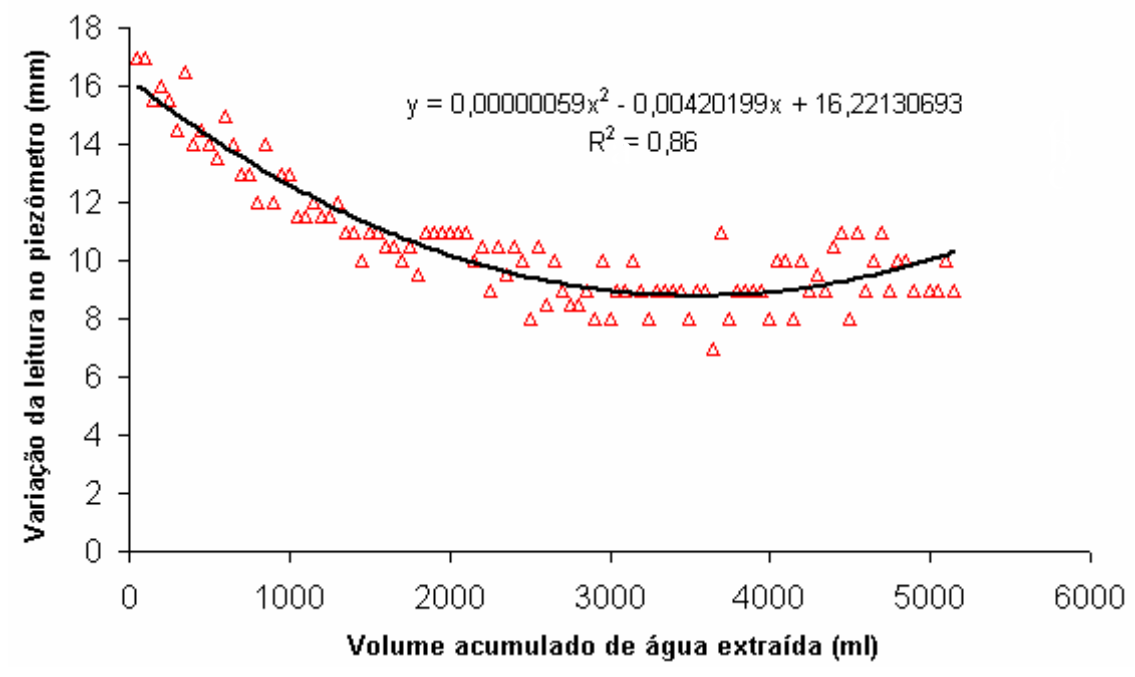

Figura 10 - Variação das leituras observadas no piezômetro, em conseqüências de extrações sucessivas de volumes constantes de $50 \mathrm{ml}$ de fluído (água), em três células de pesagem interligadas hidraulicamente 
$\Delta L=0,00000059 V a^{2}-0,00421989 V a+16,221306935 \quad r^{2}=0,862$

em que,

$\Delta L$ - Variação de leituras (mm);

$\mathrm{Va}$ - Volume acumulado de fluido removido (ml).

O volume ideal é aquele que corresponde ao ponto de mínimo da Equação 1, sendo este encontrado após realizarmos a derivada primeira $\left(\frac{\partial y}{\partial x}\right)$ da função, que corresponde:

$\frac{\partial y}{\partial x}=0,000001188 V a-0,00421989$

Resolvendo a Equação 2 após a definição da tangente igual a zero (ponto de mínimo), encontra-se um volume ideal de $3573 \mathrm{ml}$, como segue:

$\frac{\partial y}{\partial x}=0$

$0,000001188 \mathrm{Va}-0,00421989=0$

$V a=3573$

Isto definiu o volume adequado de fluido empregado nas células hidráulicas dos lisímetros utilizados na pesquisa, que foi de aproximadamente 3,6 litros, totalizando 10,8 litros por sistema de pesagem (três células de carga).

Silva et al. (2003), verificaram em um lisímetro de pesagem hidráulica de 4,8 toneladas, que as diferenças de leituras permaneciam constantes quando a variação entre a área de contato das células e as bases que as apóiam era mínima. Esta situação é 
considerada ideal para o funcionamento, porque as variações de leituras permanecem lineares para diferentes variações de massa no lisímetro.

\subsubsection{Calibração das células com equipamento padrão e transdutor}

As Figuras 11 e 12 indicam alto coeficiente de determinação $\left(r^{2}>0,99\right)$, para a relação entre o acréscimo de massa e a leitura piezométrica (leitura visual), os sinais das células de carga eletrônica e transdutor de pressão. Também houve alto coeficiente entre as leituras no piezômetro e os sinais elétricos das células de carga eletrônica.
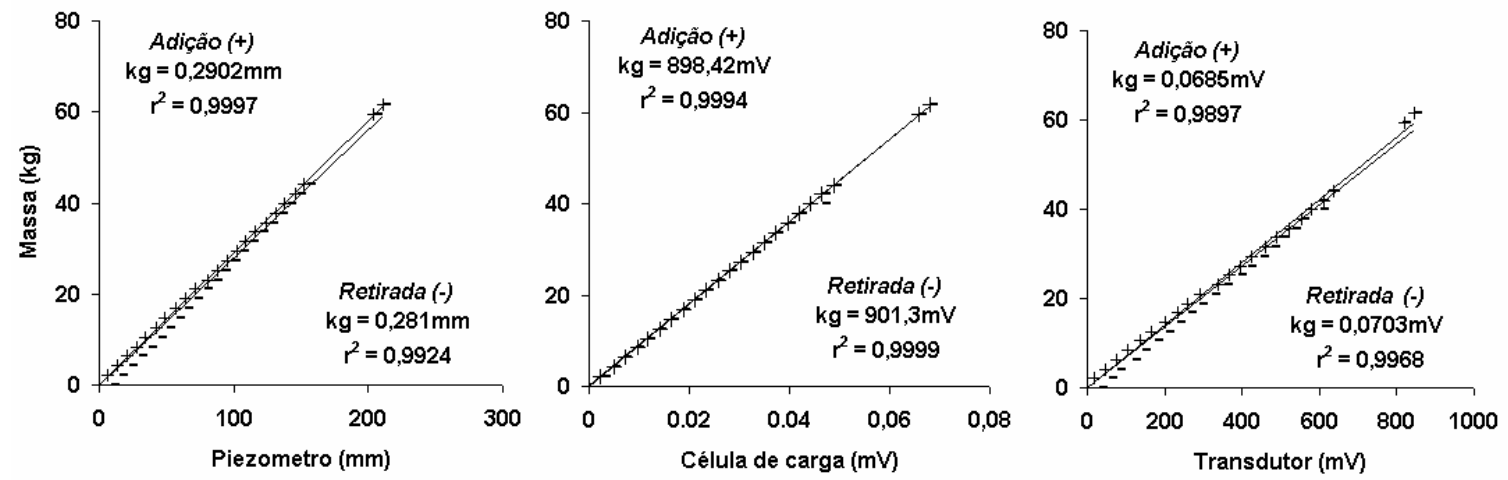

Figura 11 - Relações entre a variação de massa e a leitura piezométrica, sinais elétricos das células eletrônicas, e transdutor de pressão
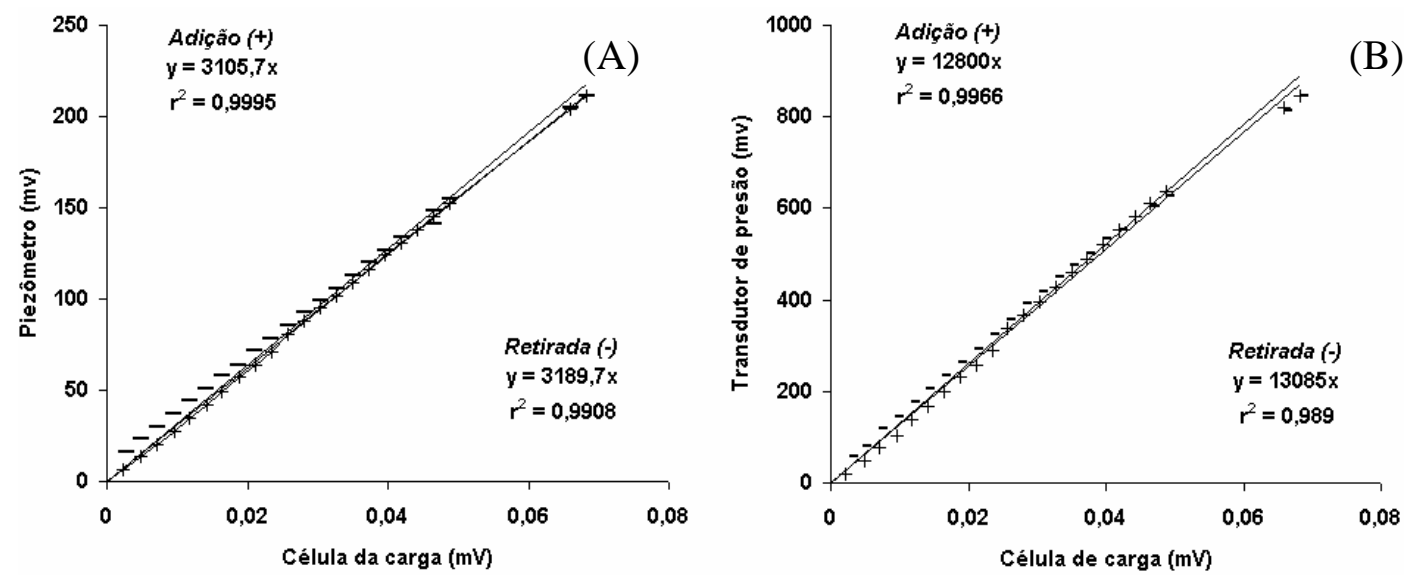

Figura 12 - Relações entre voltagens de saída das células de carga eletrônicas com leituras piezométricas (A), e transdutor de pressão (B)

As calibrações realizadas em campo permitiram obter os coeficientes lineares, como mostra a Figura 13. Ela corresponde a variação da leitura no piezômetro em relação 
aos pesos adicionados e depois retirados $(n=40)$, para os quatros lisímetros instalados no campo.

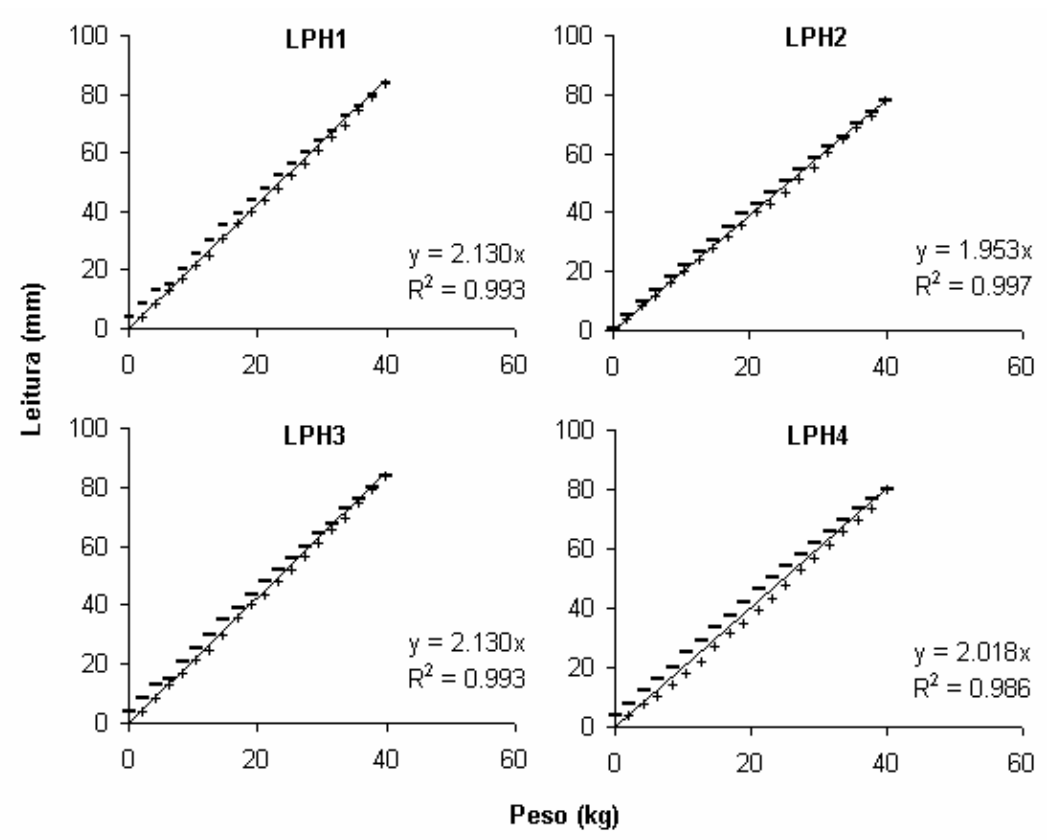

Figura 13 - Correlações entre valores de leituras observados no piezômetro e pesos adicionados (+) e/ou retirados (-) para determinação dos coeficientes de calibração dos lisímetros de pesagem hidráulica

Os coeficientes lineares de calibração obtidos (2,130; 1,953; 2,130 e 2,018) foram aplicados para converter os valores de leitura dos piezômetros, em mm, para litros de água evapotranspirados. Para isto, relacionou-se o valor referente à variação de massa do lisímetro (mm), para dois dias consecutivos, com seu respectivo coeficiente. Na prática o olho humano sendo capaz de ler variação de 0,5 mm no piezômetro, assim, em média, a menor variação de massa detectada nos lisímetros de pesagem hidráulica foi aproximadamente 0,245 kg, o que corresponde a 0,245 mm dos componentes do balanço hídrico.

Vale ressaltar que a aplicação de lisímetros de pesagem hidráulica na determinação diária do consumo hídrico dos cultivos, o efeito da temperatura é minimizado quando as leituras são realizadas sempre na mesma hora do dia, por isso, não recomenda-se a utilização deste equipamento para determinações com intervalos menores que 24 horas. 


\subsection{Conclusões}

O arranjo das células de carga hidráulica em forma de triangulo eqüilátero promoveu distribuição equilibrada de forças, boa estabilidade e precisão nas medidas.

O estabelecimento do volume ideal de fluído na célula de carga hidráulica proporciona relações lineares entre a carga e a leitura piezométrica, e consequentemente, melhor desempenho dos lisímetros.

As correlações entre os valores de variação de massa e as leituras do piezômetro, célula eletrônica e transdutor apresentaram relações lineares, com coeficientes de determinação $\mathrm{r}^{2}$ maiores que 0,98 .

O transdutor de pressão acoplado às células hidráulicas permite o monitoramento instantâneo e registro automático em sistemas de aquisição (datalogger), com sensibilidade de $\pm 0,007 \mathrm{~kg}$.

Na prática o olho humano sendo capaz de ler variação de 0,5 mm no piezômetro, para este equipamento com área de exposição igual a $1 \mathrm{~m}^{2}$, a menor variação de massa detectada foi aproximadamente $0,245 \mathrm{~kg}$, que corresponde a 0,245 mm nas componentes do balanço hídrico. 


\section{DETERMINAÇÃO DA EVAPOTRANSPIRAÇÃO DE MARACUJAZEIROS UTILIZANDO LISÍMETRO DE PESAGEM HIDRÁULICA}

\section{Resumo}

O objetivo deste estudo foi determinar a evapotranspiração e o coeficiente de cultivo de maracujazeiros cultivados em linhas com direção Norte-Sul e Leste-Oeste. Este trabalho foi conduzido no período de dezembro de 2003 a janeiro de 2005, na área experimental de irrigação, na Fazenda Areão do Departamento de Engenharia Rural da Escola Superior de Agricultura "Luiz de Queiroz" - ESALQ/USP (Piracicaba-SP). Transplantaram-se mudas de maracujazeiro amarelo (Passiflora edulis Sims f. flavicarpa Deg), cv. IAC 275, com 83 dias após a germinação, para duas parcelas experimentais definidas pela direção da espaldeira. Para a estimativa do consumo de água pelas plantas, utilizaram-se quatro lisímetros de pesagem hidráulica, iguais, sendo dois por parcela. Nos lisímetros de pesagem hidráulica o consumo medido, em litros planta ${ }^{-1} \mathrm{dia}^{-1}$, foi ajustado de acordo com a área foliar da planta instalada, para hipoteticamente uniformizar o desenvolvimento vegetativo, permitindo assim, compará-las entre si. A lâmina acumulada até o 450 dias após o plantio (DAP) para a parcela Norte-Sul foi de $1171 \mathrm{~mm}$, superior a $1083 \mathrm{~mm}$ acumulado na parcela Leste-Oeste. Os valores extremos de consumo foram em média $5 \mathrm{~L}_{\text {planta }}{ }^{-1} \mathrm{dia}^{-1}$, durante o outono e inverno, e $8 \mathrm{~L}_{\text {planta }}{ }^{-1} \mathrm{dia}^{-1}$, no Verão. Não houve diferença significativa para a ETC das parcelas nos meses de menor disponibilidade energética. Foram determinados coeficientes de cultivo de 0,6 para a fase de crescimento vegetativo apical, 0,9 para a fase de crescimento vegetativo lateral, 1,2 para a fase de floração e frutificação, 1,0 para a fase de maturação dos frutos, 0,8 para a fase pósmaturação dos frutos. 


\section{Summary}

The objective of this work was to determine the evapotranspiration and crop coefficient of the passionfruit in experimental units with rows planted based on NorthSouth and East-West directions. The experiment was carried out from December of 2003 to January of 2005, at the experimental irrigation farm of the Engineering Department College of Agriculture Luiz de Queiroz - ESALQ/USP in Piracicaba, São Paulo, State. Brazil. The 83-day-old passiflora seedlings (Passiflora edulis Sims f. flavicarpa Deg cv. IAC 275) were transplanted to experimental units, with trellis defined in accordance to the directions. In order to estimate the evapotranspiration, were used four hydraulic weighing lysimeters, being two in each direction of plant row. The daily evapotranspiration in liters per plant was adjusted in accord to leaf area present in each lysimeter so that uniform the vegetative development hypothetically and compare the values themselves. The accumulative depth at 450 days after transplant (DAP) for North-South unit was $1171 \mathrm{~mm}$ higher than $1083 \mathrm{~mm}$ for East-West. The average of extremes values for evapotranspiration was $5 \mathrm{~L}_{\text {plant }}{ }^{-1}$ day $^{-1}$ for autumn and winter and $8 \mathrm{~L}_{\text {plant }}{ }^{-1}$ day $^{-1}$ for summer period. No significant differences were found for ETc for units in months of lower energetic availability. The values for crop coefficient were 0.6 for apex vegetative growth, 0.9 for lateral vegetative growth, 1.2 for flowering and fruit development, 1.0 for fruit maturation and 0.8 for post-maturation period.

\subsection{Introdução}

Até metade da década de 1990, havia pouca pesquisa no mundo sobre irrigação na cultura do maracujazeiro. O aumento da área cultivada impulsionou a procura por informações em vários aspectos, entre eles, quanto às necessidades hídricas da cultura, adequação de sistemas e práticas de manejo da irrigação. Além disso, o conhecimento da evapotranspiração e seus coeficientes de cultivo são importantes parâmetros aplicados na elaboração de projetos e dimensionamento de sistemas.

Aboukhaled (1982) define lisímetros como equipamentos padrão, de alta precisão e importantes na determinação da evapotranspiração dos cultivos e conseqüentemente seus 
coeficientes $(K c)$, no entanto, são equipamentos caros, empregados apenas em experimentação científica. No Brasil, o primeiro lisímetro de pesagem hidráulica foi construído e descrito por Rodrigues (1987), para estudos de evapotranspiração de grama (ETo), na cidade de Parnamirim, Pernambuco. Posteriormente outros autores (Freitas, 1994; Costa, 1999 e Silva, 2000) construíram e utilizaram lisímetros de pesagem hidráulica para obtenção da evapotranspiração de referência em grama.

Dessa maneira, o objetivo deste trabalho foi o de determinar a evapotrasnpiração de maracujazeiros e seus respectivos coeficientes de cultivo em duas áreas com orientações de plantio Norte-Sul e Leste-Oeste, empregando-se lisímetros de pesagem hidráulica.

\subsection{Material e Métodos}

\subsubsection{Localização e descrição do sistema de cultivo}

O estudo foi conduzido no período de dezembro de 2003 a janeiro de 2005, na área experimental de irrigação, na Fazenda Areão do Departamento de Engenharia Rural da Escola Superior de Agricultura “Luiz de Queiroz” - ESALQ/USP (Piracicaba-SP). A área experimental tinha declividade de $3 \%$, inclinada para o Oeste, localizada nas coordenadas geográficas de $-22^{\circ} 43^{\prime} 33^{\prime}$ ' de latitude, 47 38’0'’ de longitude e altitude de $576 \mathrm{~m}$. O clima da região é do tipo Cwa segundo a classificação climática de Köppen, sendo, subtropical úmido com estiagem no inverno, temperatura média anual de $21,1^{\circ} \mathrm{C}$ e precipitação de aproximadamente $1250 \mathrm{~mm}$ (Setelhas \& Pereira, 2000). O cultivo foi realizado em solo Nitossolo vermelho segundo o sistema brasileiro de classificação de solos (EMBRAPA, 1999).

Em 25/10/2003 transplantaram-se mudas de maracujazeiro amarelo (Passiflora edulis Sims f. flavicarpa Deg), cv. IAC 275, com 83 dias após a germinação, em duas parcelas experimentais. A parcela 1, possuía 155 plantas distribuídas em 15 linhas de plantio direcionadas no sentido Norte-Sul e a parcela 2, com 102 plantas distribuídas em 11 linhas orientadas no sentido Leste-Oeste (Figura 1).

Nas duas parcelas, todas as plantas foram conduzidas em sistema de suporte do tipo espaldeira vertical com um fio de arame (AWG 12) na altura de 1,8 m, fixado no topo 
de mourões espaçados de $4 \times 4 \mathrm{~m}$. As mudas foram transplantadas para covas com dimensões de 0,4 $\times$ 0,4 $\times$ 0,4 m, fertilizadas de acordo com Van Raij et al., (1996), disposta a 2 m dos mourões, de acordo com a direção de plantio da parcela. Dessa forma, o espaçamento entre plantas também foi de $4 \times 4 \mathrm{~m}$ e área total de $0,51 \mathrm{ha}^{-1}$.

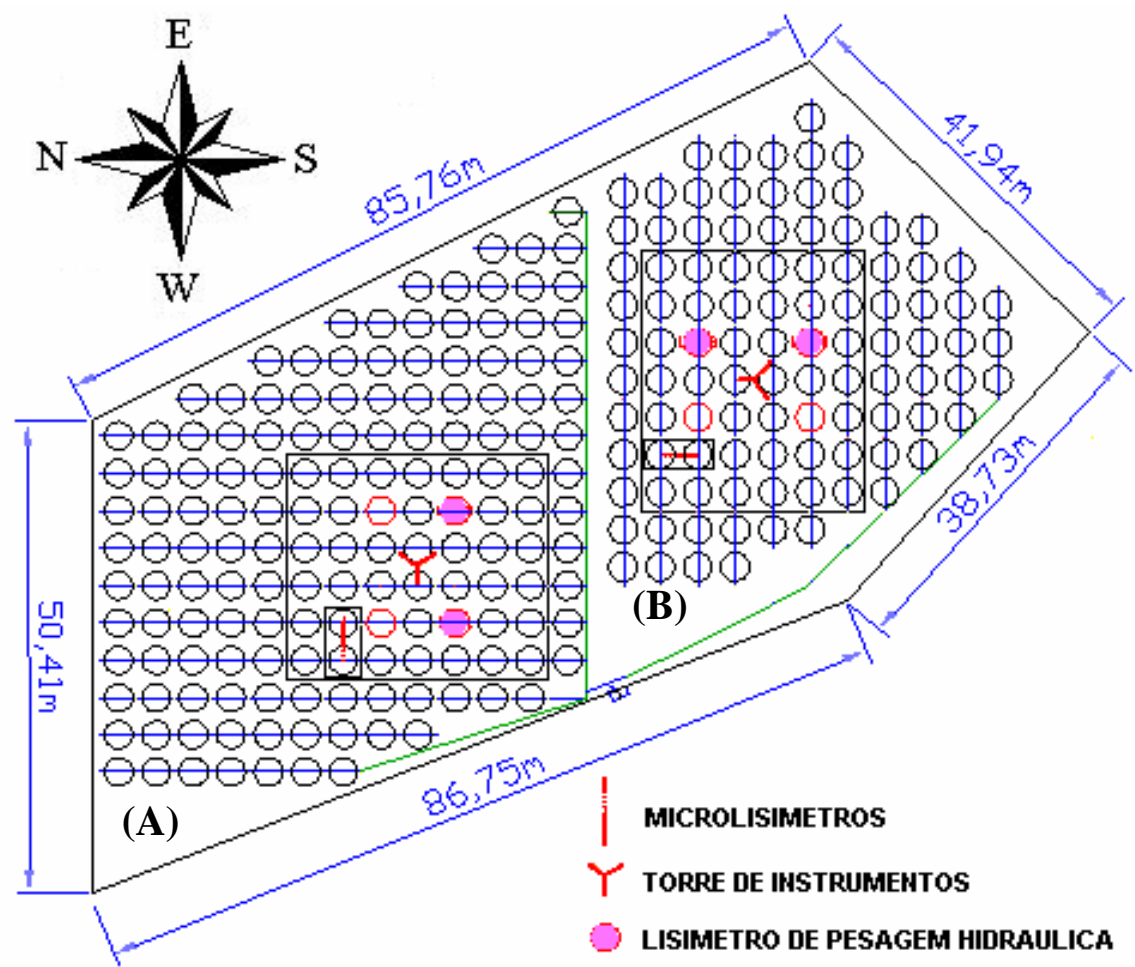

Figura 1 - Croqui da área experimental com duas parcelas definidas pela orientação das linhas de cultivo; A) linhas no sentido Norte-Sul e B) Leste-Oeste

Na determinação da evapotranspiração, utilizaram-se quatro lisímetros de pesagem hidráulica $(L P H)$, iguais, com dimensões de 1,15 m de diâmetro e 0,56 m de profundidade, sendo dois por parcela. Os $L P H$ possuíam as seguintes partes: (i) Contêineres - associação de dois tanques, sendo um externo de placas premoldadas e outro interno, de polietileno; (ii) Sistema hidráulico de pesagem - formado por três células de carga hidráulica, dispostas em ângulo de $120^{\circ}$; (iii) Sistema transmissor de pressão - conecções tipo bico com rosca, anéis de aço inox, tubo de polietileno transparente e adaptador de PVC. (iv) Sistema de leitura - composto por um manômetro de "poço" com mercúrio e água (líquidos manométricos), escala milimétrica, conectores, microtubos de silicone e tubo 
capilar de vidro; e (v) Sistema de drenagem - drenagem realizada por sucção ou sifonamento. Construiu-se com tubos perfurados de PVC, cotovelos e um envelope de brita recoberta com bidim P-30.

Sendo o maracujazeiro uma planta trepadeira, construiu-se uma estrutura de suporte específica para a planta do lisímetro, independente daquela empregada no sistema de condução das plantas vizinhas (Figura 2). Os suportes foram construídos com 1,8 m de altura, feitos com tubos de aço galvanizado de $25 \mathrm{~mm}$ de diâmetro. Cada suporte possuía ainda, um tubo de $4 \mathrm{~m}$ preso horizontalmente na parte superior e alinhado na direção de plantio da parcela, para simular o sistema de condução da cultura. Esse suporte, semelhante a um tripé, teve seus “pés” parafusados ao tanque interno, somando-se à massa total do lisímetro. Desta maneira, a variação de leitura dava-se em função da variação de massa de água perdida por evapotranspiração.

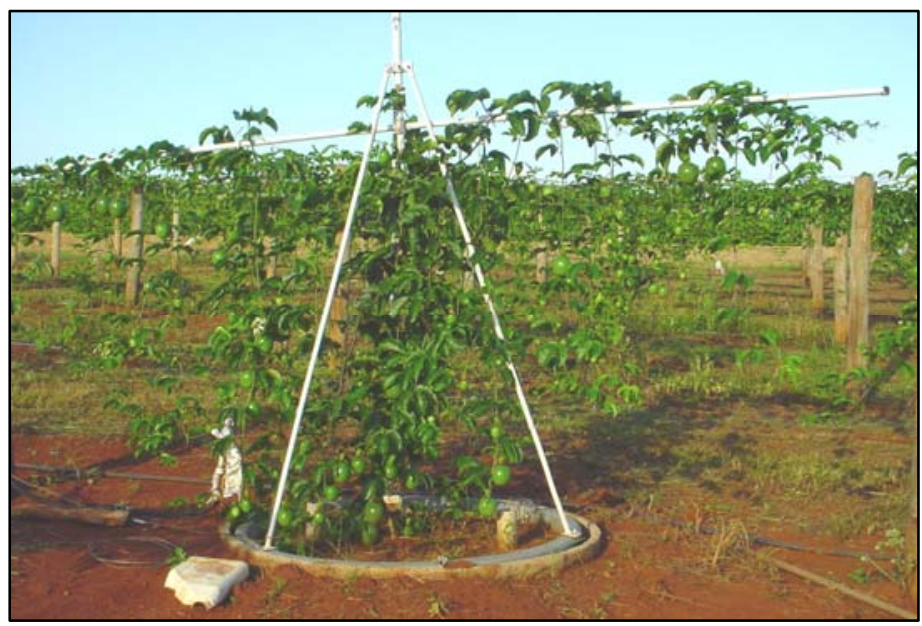

Figura 2 - Detalhe do suporte empregado no sistema de condução para plantas dos lisímetros

Foram utilizadas 4 estações de 3 tensiômetros, nas profundidades de 0,10, 0,30 e 0,45 m, sendo uma estação por lisímetro. As plantas das parcelas foram irrigadas por microaspersores, com raio de alcance de $1,5 \mathrm{~m}$ e vazão de $40 \mathrm{~L} \mathrm{~h}^{-1}$, acionados sempre que o potencial de água no solo de -20 kPa era atingido na profundidade de 0,10 m. Souza (2000) e Lucas (2002) verificaram ocorrência de mais de 80\% das raízes do maracujazeiro nesta camada de solo, e definiram o potencial de água no solo de $-20 \mathrm{kPa}$ como limite para o manejo da irrigação. As irrigações das plantas nos lisímetros foram realizadas manualmente 
com irrigador de jardim. Esse procedimento foi adotado para reposição imediata da água no lisímetro e melhor controle do volume aplicado. A irrigação das plantas das parcelas, para cada orientação de plantio, foi determinada de acordo com o consumo médio de seus lisímetros. Para isso, considerou-se a evapotranspiração acumulada desde a irrigação anterior, até o estabelecimento do limite potencial de água no solo (-20 kPa), baseados nos valores médios fornecidos pelos dois lisímetros da respectiva parcela.

\subsubsection{Evapotranspiração de referência (ETo) e de cultivo (ETc)}

A estimativa da evapotranspiração de referência (ETo) foi realizada de acordo com a parametrização proposta pela FAO (Allen et al, 1998), utilizando os dados da Estação Agrometeorológica localizada a $100 \mathrm{~m}$ do local do experimento. Esta estação possuía um sistema de aquisição eletrônica de dados (CR21X, Campbell Scientific, Logan, Utah, EUA) programado para realizar medidas a cada segundo, com médias a cada hora, dos seguintes sensores: Saldo-radiômetro (modelo Q7.1 - Radiation Energy Balance Systems Inc., Seattle, Washington, EUA); anemômetro de canecas e um sensor de direção de vento (modelo 03001 Wind Sentry anemometer and Vane, R. M. Young, Traverse City, Michigam EUA); sensor de fluxo de calor no solo (modelo HFT3, Rebs, Seattle, Washington, EUA); umidade e temperatura do ar (modelo HTM45C, Vaisala, Helsink, Finlândia); radiação global (modelo LI-200, Li-Cor, Lincoln, Nebraska USA) e pluviômetro (modelo TE525, Texas Eletronics Inc., Dallas,Texas, EUA).

Para a determinação da evapotranspiração da cultura $(E T c)$, realizaram-se às 7:30 leituras diárias nos lisímetros, visualizando-as diretamente na escala manométrica. Partindo-se da leitura inicial da massa do lisímetro equivalente ao balanço hídrico do dia anterior, iniciou-se a coleta de dados para determinação da (ETC). Em seguida mediu-se o volume de água drenada $(V d)$, também referente ao balanço do dia anterior, se ocorresse uma precipitação elevada. O volume drenado era computado pela diferença de leituras dos valores lidos antes, e após a retirada do excedente de água do lisímetro. Nos dias sem ocorrência de chuva e conseqüentemente sem drenagem, $V d=0$ e $V p=0$, em que, $V p$ corresponde ao volume precipitado. A drenagem, quando necessária, foi sempre realizada no início da manhã. A evapotranspiração resultante do balanço hídrico $\left(V_{B H}\right)$, em litros, foi calculada pela seguinte equação: 
$V_{B H}=V e t-V d+V p$

em que,

$V e t=\frac{\Delta L}{f}$

$V d=\frac{\Delta L^{*}}{f}$

$V p=P S$

$\Delta L=L o-L d$

em que,

$V_{B H}-$ volume de água resultante do balanço hídrico (L);

Vet - volume evapotranspirado (L);

$V d$ - volume drenado (L);

$V p$ - volume precipitado no lisímetro (L);

$P$ - $\quad$ precipitação (mm);

$\Delta L$ - variação de leitura do lisímetro no período (mm);

Lo - leitura anterior do lisímetro (mm);

$L d$ - leitura atual do lisímetro (mm);

f- $\quad$ coeficiente de calibração do lisímetro ( $\mathrm{mm} \mathrm{kg}^{-1}$ de água);

$\Delta L^{*}$ - variação de leitura do lisímetro promovida pela drenagem (mm);

$S$ - $\quad$ área da superfície do lisímetro $\left(\mathrm{m}^{2}\right)$.

Apesar das plantas cultivadas nos lisímetros aparentarem mesmo porte, elas possuíam valores distintos de área foliar, portanto, necessitou-se corrigir os dados de consumo diário antes de realizar as comparações entre as evapotranspirações dos lisímetros nas parcelas. A correção do consumo, em litros, foi dada pela relação entre o consumo 
medido e a área foliar da planta do lisímetro, em $\mathrm{L} \mathrm{m}^{-2}$. Depois, realizou-se o produto de cada consumo relativo pela área foliar média das plantas dos 4 lisímetros $(\overline{A f})$, como descrito a seguir:

$V c=\left(\frac{V e t}{A f}\right) \overline{A f}$

em que,

Vc - volume corrigido do lisímetro (L);

Vet - volume evapotranspirado do lisímetro (L);

Af - $\quad$ área foliar da planta do lisímetro $\left(\mathrm{m}^{2}\right)$;

$\overline{A f}$ - área foliar média das plantas para os quatro lisímetros $\left(\mathrm{m}^{2}\right)$.

Determinou-se a ETc, em mm, com base na área correspondente a máxima região de exploração das raízes $\left(2 \mathrm{~m}^{2}\right)$, com finalidade de possibilitar aplicação desta metodologia para diferentes espaçamentos de maracujazeiros e superfície molhada do solo, promovida por outros sistemas de irrigação. A área máxima de exploração das raízes utilizada no cálculo da ETc foi estabelecida com base nos estudos de distribuição de raízes realizados por Sousa (2000) e Lucas (2002). Os autores verificaram para o mesmo solo estudado, sob cultivos irrigados por sistema de gotejamento, que as raízes de maracujazeiros se estendiam radialmente até a distância de 0,8 m do tronco da planta (área igual a 2,01 $\mathrm{m}^{2}$ ).

Diante disso, calculou-se o “déficit de recobrimento do lisímetro" $(\Delta R)$, em percentagem, que corresponde a diferença entre a área de controle e a razão de área do lisímetro pela área de exploração do sistema radical $(A z)$. Sendo $A z$ igual a $2 \mathrm{~m}^{2}$, e a área útil do lisímetro igual a $1,03 \mathrm{~m}^{2}$, logo, o $\Delta R$ empregado foi de 48,5\%, obtido de acordo com a Equação 12.

$$
\Delta R=\left[1-\frac{\text { Alis }}{A z}\right] 100
$$


Para o calculo do déficit de área do lisímetro $(\Delta A)$, em $\mathrm{m}^{2}$, utilizou-se a Equação 13 ,

$\Delta A=\left(\frac{\Delta R}{100}\right) A z$

em que,

$\Delta A$ - Déficit de área do lisímetro $\left(\mathrm{m}^{2}\right)$;

$\Delta R$ - Déficit de recobrimento do lisímetro (\%);

Alis - Área do lisímetro $\left(\mathrm{m}^{2}\right)$;

$A z$ - Área de exploração do sistema radical $\left(\mathrm{m}^{2}\right)$.

Em seguida, estimou-se a evaporação do solo (Ev) correspondente ao $\Delta A$ do lisímetro $\left(0,97 \mathrm{~m}^{2}\right)$. Para isto adotou-se um coeficiente de evaporação do solo médio (Ke méd ), igual a 0,6, que foi estabelecido durante ciclos de secamento do solo, na área experimental. O Ke méd foi determinado com um lisímetro de 2,01 $\mathrm{m}^{2}$, mantido sem vegetação e instalado a $100 \mathrm{~m}$ da área experimental, e por dois conjuntos de nove microlisímetros, sendo um conjunto por parcela experimental, disposto transversalmente às linhas de cultivo e espaçados entre si de 0,5 m (Figura 1). Obteve-se o valor de $K e_{\text {med }}$ pela relação entre $E v$ e ETo, para uma freqüência de irrigação de 2 dias. Assim, reorganizando os termos desta relação tem-se:

$E v=K e_{\text {méd }} E T o$

em que,

Ev - Evaporação do solo (mm dia $\left.{ }^{-1}\right)$;

$K e_{\text {méd }}$ - Coeficiente de evaporação médio $(0,6)$;

ETo - Evapotranspiração de referência $\left(\mathrm{mm} \mathrm{dia}^{-1}\right)$.

De posse da $E v$ obteve-se o volume de água evaporada do solo ( $V e$ ), referente ao déficit de área do lisímetro, em litros dia ${ }^{-1}$, por: 
$V e=\triangle A E v$

Conseqüentemente, a Equação 16 fornece o volume total evapotranspirado diariamente pelo maracujazeiro (VT), em litros dia $^{-1}$, estabelecido a partir do volume corrigido fornecido pelo lisímetro (Equação 11), somado ao volume evaporado determinado pela Equação 15.

$V T=V c+V e$

onde,

$V T$ - volume total evapotranspirado $\left(\mathrm{L} \mathrm{dia}^{-1}\right)$;

VC - volume corrigido pela área foliar $\left(\mathrm{L} \mathrm{dia}^{-1}\right)$;

$V e$ - volume evaporado ( $\left.\mathrm{L} \mathrm{dia}^{-1}\right)$.

Assim, a ETc, em mm, foi obtida de acordo com a Equação 17.

$E T c=\frac{V T}{A z}$

em que,

ETC - Evapotranspiração da cultura (mm dia $\left.{ }^{-1}\right)$;

$V T$ - Volume total evapotranspirado em um dia $\left(\mathrm{L} \mathrm{dia}^{-1}\right)$;

$A z$ - Área de exploração do sistema radical $\left(\mathrm{m}^{2}\right)$.

\subsubsection{Determinação do coeficiente de cultivo $(\mathrm{Kc})$}

Para determinar o coeficiente de cultivo $(K c)$, aplicou-se a relação ETc/ETo (Jensen, 1968), como segue:

$K c=\frac{E T c}{E T o}$ 
em que,

Kc - Coeficiente de cultivo (adimensional);

ETc - Evapotranspiração da cultura ( $\left.\mathrm{mm} \mathrm{dia}^{-1}\right)$;

ETo - Evapotranspiração de referência $\left(\mathrm{mm} \mathrm{dia}^{-1}\right)$.

Em irrigação localizada há necessidade de integrar um coeficiente de redução $(K r)$ para repor o volume de água, em litros planta ${ }^{-1}$, requerido na zona de exploração do sistema radical (Keller e Karmeli, 1974). Neste trabalho utilizou-se o valor de $\mathrm{Kr}$ modificado obtido pela Equação 25, descrita a seguir:

$K r=\frac{A z}{A e}$

em que,

$A z$ - Área máxima de exploração radical $\left(\mathrm{m}^{2}\right)$

$A e$ - Área útil da cultura $\left(\mathrm{m}^{2}\right)$

Os consumos das parcelas Norte-Sul e Leste-Oeste foram analisados estatisticamente de acordo com teste de hipótese (teste F).

\subsubsection{Informações adicionais}

As podas de condução e de formação foram realizadas de acordo com Ruggiero et al., (1996), assim como, as fertirrigações foram realizadas igualmente para todas as plantas do experimento, inclusive nas dos lisímetros, seguindo a recomendação de adubação e calagem para o Estado de São Paulo (Raij et al., 1996).

Os microaspersores funcionavam pressurizados a 3,1 $\mathrm{kgf}^{-2}$ com taxa de aplicação $40 \mathrm{~L} \mathrm{~h}^{-1}$, e promovia circunferência molhada próximo a 1,5 m de raio.

As plantas invasoras foram controladas com herbicida, numa faixa de $2 \mathrm{~m}$ abaixo das espaldeiras, e nas entrelinhas com roçadora tratorizada. 


\subsection{Resultados e Discussão}

\subsubsection{Elementos meteorológicos}

Na Figura 3 observa-se a variação de alguns elementos meteorológicos desde o período do transplantio, em outubro de 2003, até o início da maturação dos frutos do segundo cilclo, aos 450 DAP, em 17 de janeiro de 2005. Durante este período a variação das temperaturas médias mensais obtidas na área experimental acompanhou a série histórica de 50 anos para Piracicaba-SP. De acordo com Piza Júnior (1998), observações preliminares indicaram valores limites de temperatura ótima para o maracujazeiro entre 8 e $27{ }^{\circ} \mathrm{C}$. Portanto, observa-se no período avaliado que as temperaturas médias mensal permaneceram na faixa ótima para a cultura. Os valores observados de evapotranspiração de referência (ETo), também apresentaram variações normais, exceto no mês de abril que foi inferior em $41 \%$ em relação ao valor da série histórica para este mês. A precipitação pluviométrica foi o elemento que apresentou maiores variações em relação à série histórica. No mês de maio a precipitação foi 2,9 vezes superior a da série normal.

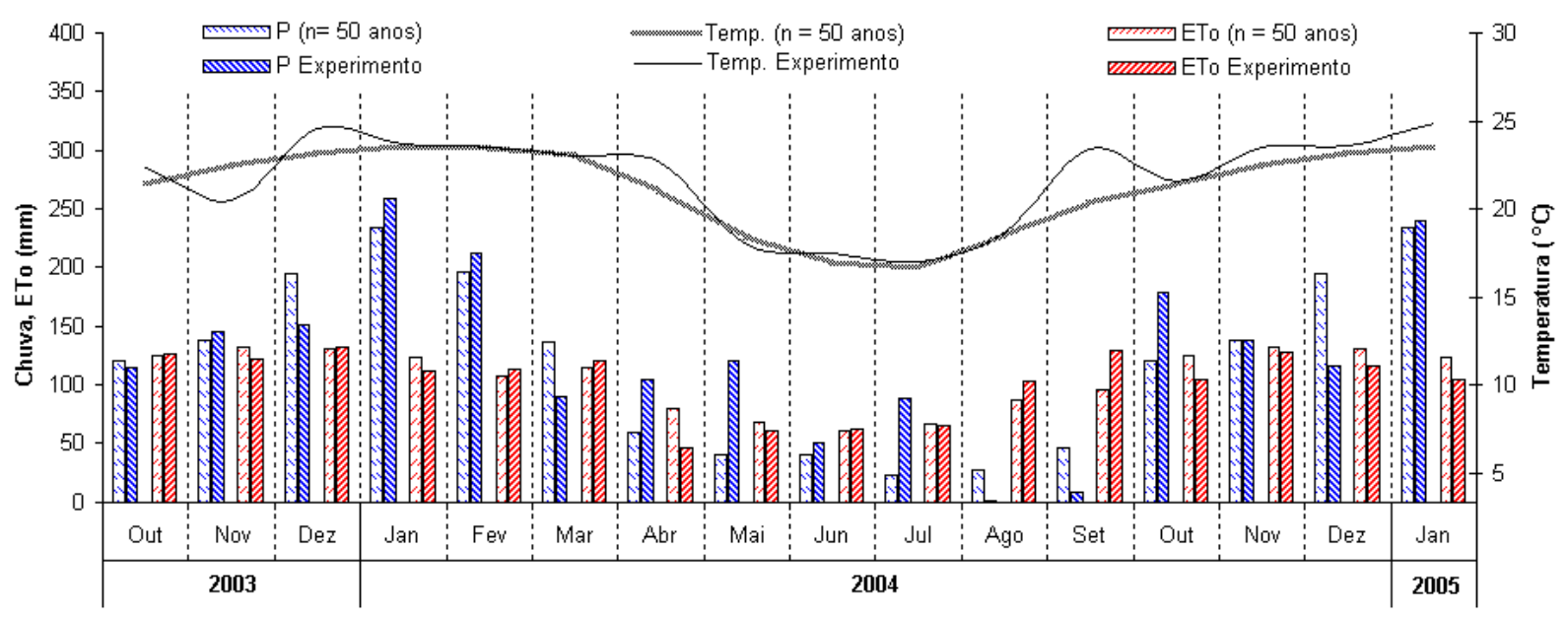

Figura 3 - Precipitação pluviométrica $(P)$, evapotaranspiração de referência (ETo) e temperaturas médias mensais (Temp) no período de outubro de 2003 a janeiro de 2005, e de série histórica de 50 anos, para Piracicaba-SP 


\subsubsection{Consumo de água pelo maracujazeiro}

Verifica-se nas curvas da Figura 4 o consumo, em litros planta ${ }^{-1} \mathrm{dia}^{-1}$, para os lisímetros de cada parcela durante o período experimental. Este consumo equivale a transpiração da cultura somado a evaporação do solo de uma área de $2 \mathrm{~m}^{2}$ de acordo com a Equação 16. Os dados originais foram ajustados por meio de uma linha de tendência do tipo média móvel de ordem 10, para possibilitar melhor visualização das curvas e interpretação dos dados.

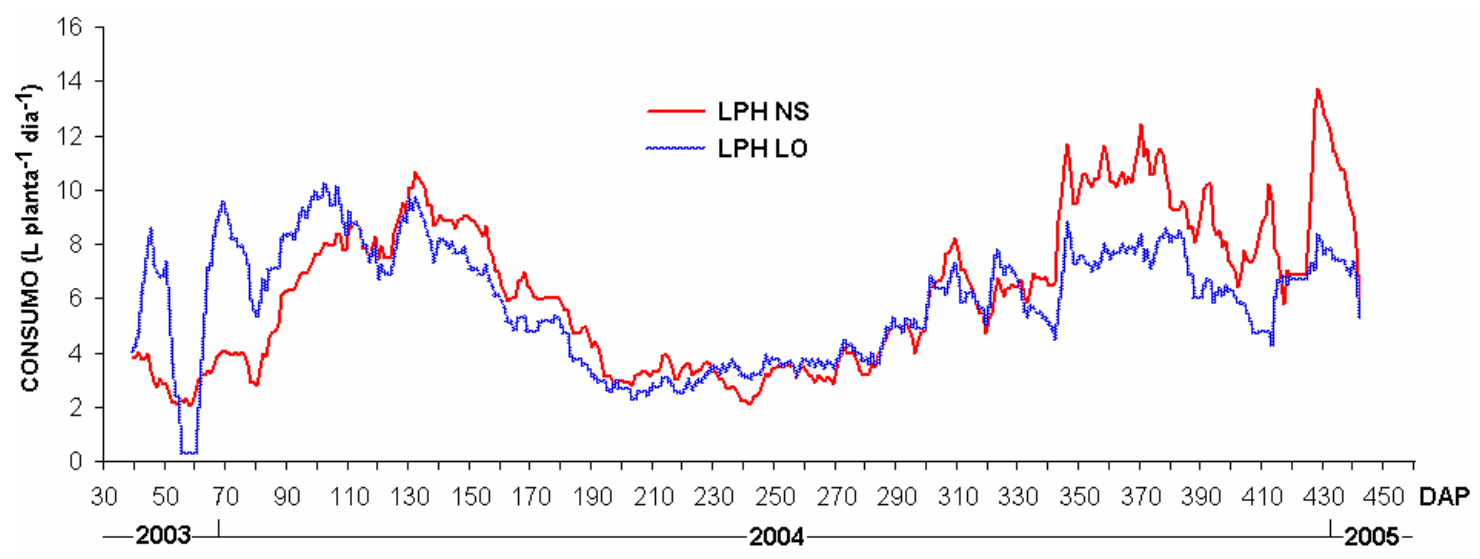

Figura 4 - Variação do consumo diário do maracujazeiro (L planta dia ${ }^{-1}$ ), determinado por lisímetros de pesagem hidráulica $(L P H)$ em cultivos com diferentes direções de linha de plantio (Norte-Sul e Leste-Oeste)

Observa-se ainda que para os três primeiros meses após implantação do cultivo que o consumo das plantas da parcela Leste-Oeste $(L O)$ foi estatisticamente superiores (Tabela 1), até próximo dos 120 DAP (meados de fevereiro), que a partir daí, foi superado sem significância estatística pelo consumo das plantas da parcela Norte-Sul (NS).

No final da estação do Outono até início da Primavera, que corresponde aproximadamente ao intervalo entre 210 e $350 D A P$, foram registrados os menores valores de consumo, em média $5 \mathrm{~L}_{\text {planta }}{ }^{-1} \mathrm{dia}^{-1}$. Isso é explicado pela baixa disponibilidade de radiação, baixa temperatura e menor demanda climática nestas estações (Figura 3). No segundo ciclo de produção da cultura, a partir da metade da estação de Primavera até os dois primeiros meses do Verão, os consumos de água nas diferentes direções de plantio voltaram a apresentar diferenças significativas, de acordo com teste de hipótese (teste F), como se verifica na Tabela 1. 
Tabela 1. Consumo médio mensal de água por maracujazeiros, em litros planta ${ }^{-1}$ dia $^{-1}$, durante o primeiro e segundo ciclo de produção, em Piracicaba-SP

\begin{tabular}{cccccc}
\hline Mês/ano & \multicolumn{2}{c}{ Parcela } & Mês/ano & \multicolumn{2}{c}{ Parcela } \\
& Norte-Sul & Leste-Oeste & & Norte-Sul & Leste-Oeste \\
\hline dez/03 (51) & 2,93 & $7,26^{*}$ & jul/04 (264) & 2,89 & 3,44 \\
jan/04 (82) & 3,59 & $7,01^{*}$ & ago/04 (295) & 4,27 & 4,36 \\
fev/04 (113) & 7,33 & $9,09^{*}$ & set/04 (326) & 6,51 & 6,59 \\
mar/04 (142) & 8,87 & 8,11 & out/04 (356) & $8,97^{*}$ & 6,59 \\
abr/04 (173) & $7,13^{*}$ & 5,86 & nov/04 (387) & $10,24^{*}$ & 7,72 \\
mai/04 (203) & 4,20 & 3,45 & dez/04 (417) & $7,86^{*}$ & 5,98 \\
jun/04 (234) & 3,35 & 3,00 & jan/05 (448) & $10,67^{*}$ & 7,32 \\
\hline
\end{tabular}

* Diferença significativa ao nível de 5\% de probabilidade (teste F).

Valor entre parênteses indica o número de dias após plantio (DAP) para o décimo quinto dia do mês avaliado.

Para buscar uma explicação da ocorrência do maior consumo verificado na parcela Norte-Sul após outubro de 2004, utilizou-se a freqüência relativa da direção diária dos ventos (Figura 5).

Observa-se na Tabela 1, que nos meses de agosto e setembro as plantas não apresentaram diferenças significativas no consumo de água. Porém, de acordo com a Figura 5, observa-se que a freqüência relativa da direção do vento Norte-Sul sobre as linhas de cultivo com direção Leste-Oeste foi de 39,45 e 51,09 \%, para os meses de agosto e setembro, respectivamente. Nos meses seguintes, a freqüência relativa da direção do vento Norte-Sul sobre o cultivo Leste-Oeste diminuiu para 30,31 \%, em outubro e 27,13 \%, em novembro. Dessa maneira, a diferença de consumo verificado para a parcela Norte-Sul, provavelmente aconteceu porque a parcela Leste-Oeste passou a ter menor interação com o vento a partir do mês de outubro, e com isso absorviam menos energia da atmosfera, diminuindo a evapotranspiração. Pelo contrário, nos meses anteriores a outubro, a parcela Leste-Oeste sofreu maior interação com o vento, consequentemente, mais energia disponível para a evapotranspiração, aproximando-se assim, do consumo das plantas da parcela Norte-Sul. 

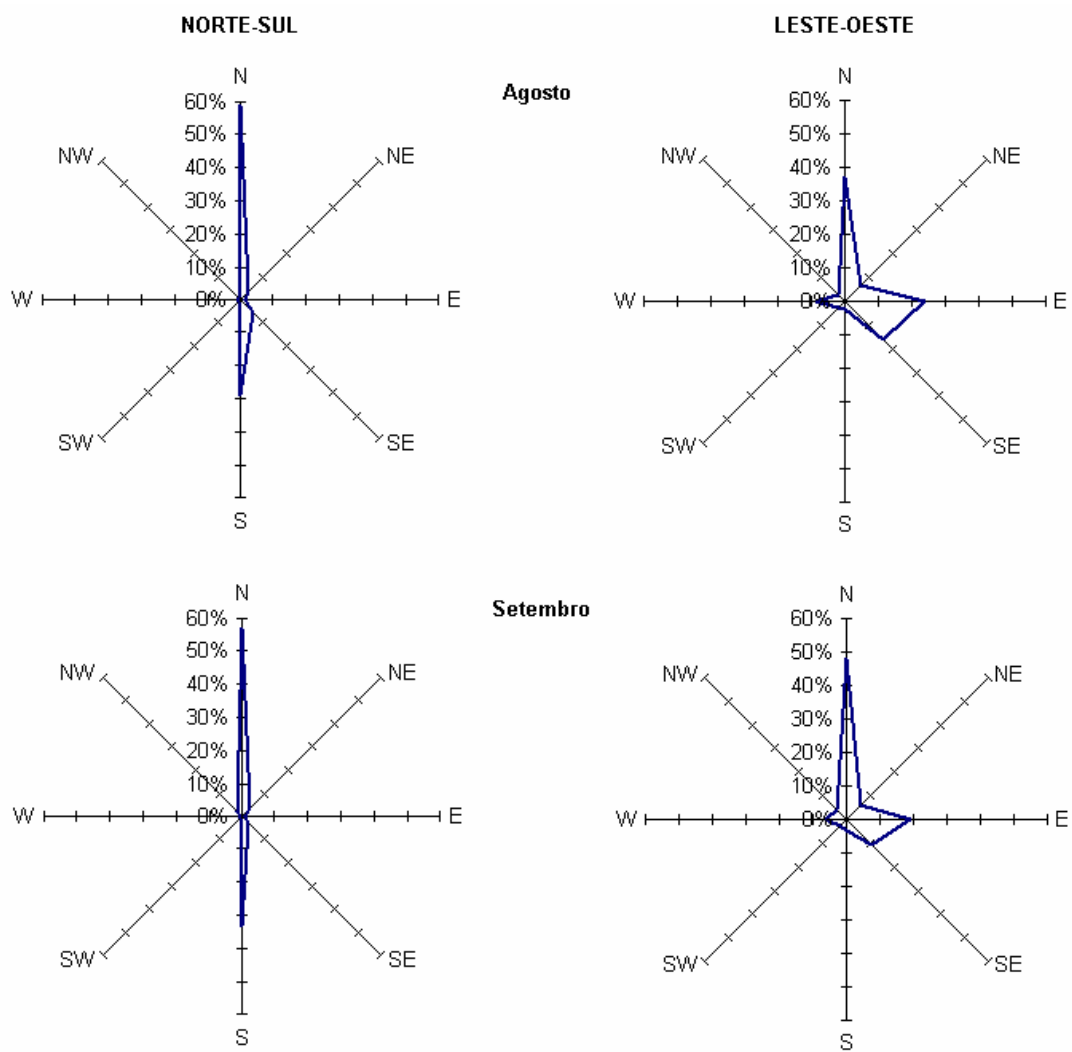

Setembro
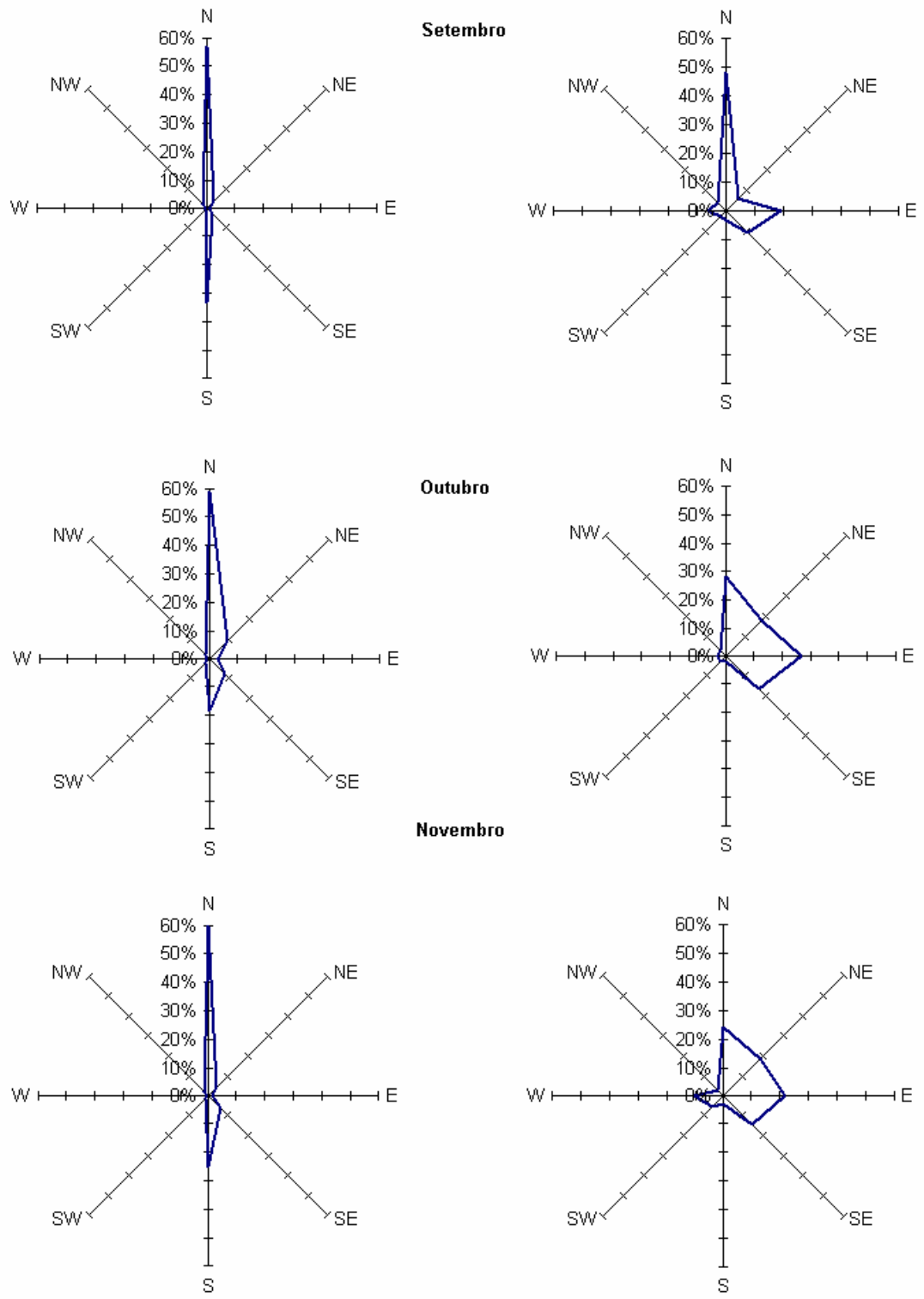

Figura 5 - Freqüência relativa da direção diária dos ventos, em duas parcelas cultivadas com maracujazeiro nas direções de plantio Norte-Sul e Leste-Oeste. 
Segundo Pereira et al., (2002), um quebra vento vegetal absorve parte da energia disponível, fazendo fotossíntese, transpirando e consumindo calor sensível do ar.

A direção do vento no interior do cultivo durante a condução do experimento foi predominante para o Norte, sendo esta perpendicular às linhas de cultivo da parcela LesteOeste, que por essa razão funcionaram como se fossem vários quebra-ventos paralelos. Por outro lado, as espaldeiras da parcela Norte-Sul forneciam pouca resistência à passagem do vento, canalizando-o entre as linhas de cultivo, e por isso promovendo pouca absorção de energia. A direção do vento registrada na estação meteorológica durante a condução do experimento foi predominantemente para o Sudeste.

\subsubsection{Evapotranspiração da cultura (ETc) e coeficiente de cultivo (Kc)}

Nos lisímetros de pesagem hidráulica $(L P H)$ o consumo medido, em litros planta ${ }^{-1}$ dia $^{-1}$, para cada lisímetro foi ajustado de acordo com a área foliar da cultura, para hipoteticamente uniformizar o desenvolvimento vegetativo das quatros plantas, permitindo assim, compará-las entre si.

A evapotranspiração acumulada do maracujazeiro, em mm, calculados a partir dos lisímetros (Equação 17), está representado na Figura 6. A lâmina acumulada até o 450 DAP representativa para a parcela Norte-Sul foi de $1.171 \mathrm{~mm}$, superior a $1.083 \mathrm{~mm}$ acumulado na parcela Leste-Oeste.

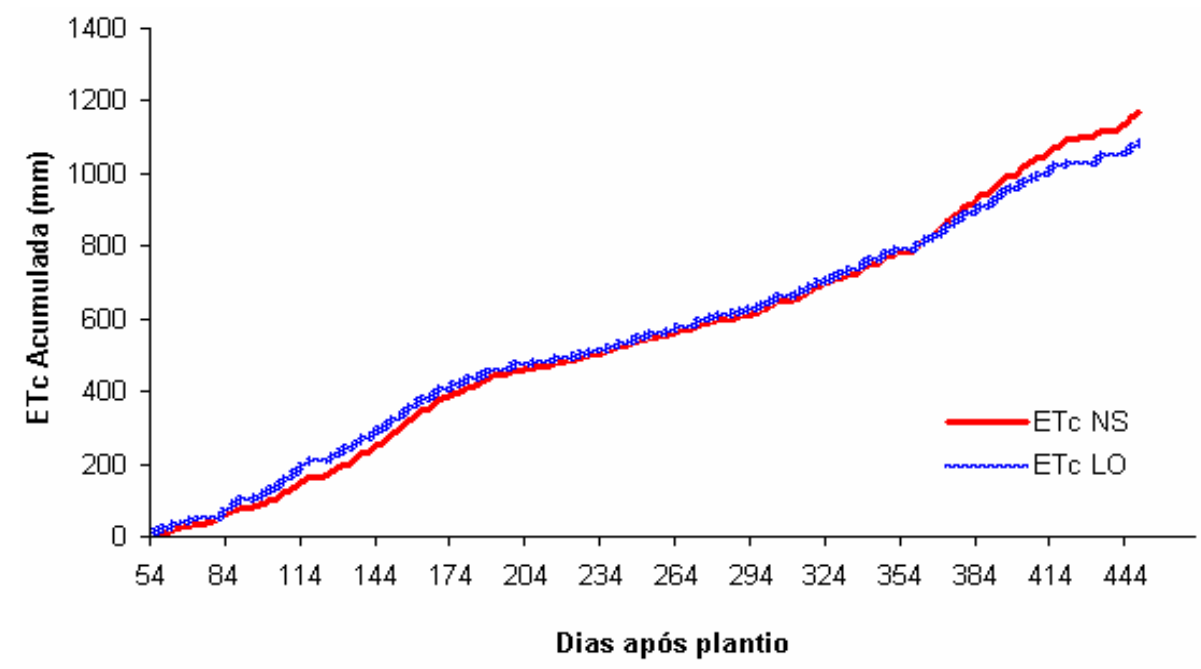

Figura 6 - Evapotranspiração da cultura acumulada por maracujazeiros com linhas de cultivo nas direções Norte-Sul (NS) e Leste-Oeste $(L O)$, determinados por lisímetros de pesagem hidráulica 
Na Figura 7 observa-se variações diárias da evapotranspiração da cultura (ETc) obtida pelos lisímetros, evapotranspiração de referência (ETo) e precipitação pluviométrica $(P)$, para as duas diferentes direções de cultivo (Norte-Sul e Leste-Oeste). Verificou-se na prática que os dias com chuva, principalmente na estação de verão tanto no $1^{\circ}$ como no $2^{0}$ ciclo de produção, ocasionaram erros mais freqüentes na determinação da evapotranspiração. Esse efeito pode ser observado nos valores divergentes de ETc gerados pelos lisímetros em comparação a ETo, nos períodos mais chuvosos, próximo dos 95 e 125 $D A P\left(1^{\circ}\right.$. ciclo) e 350 e 400 ( $2^{\circ}$ ciclo).

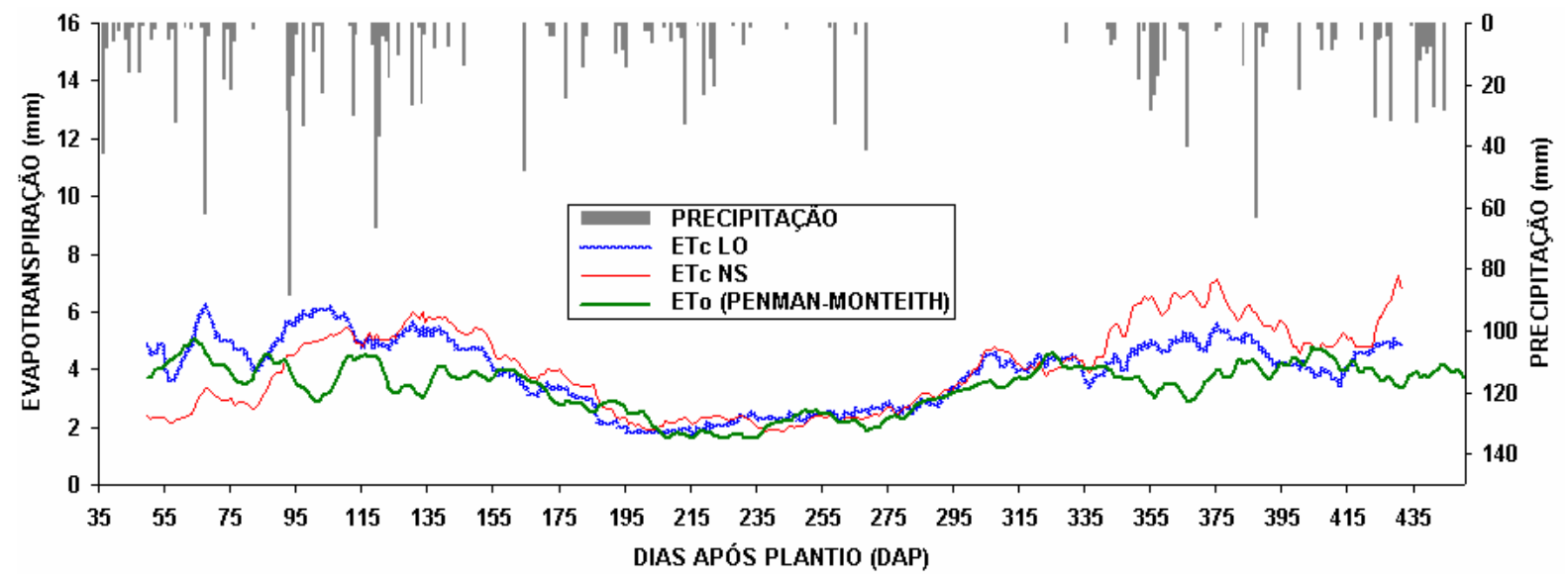

Figura 7 - Precipitação diária, evapotranspiração de referência (ETo) e evapotranspiração da cultura $(E T c)$, sobre maracujazeiros com linhas de cultivo nas direções Norte-Sul e Leste-Oeste

Os valores de coeficiente de cultivo $(K c)$ obtido para os maracujazeiros plantados no período de outubro/2003 até janeiro/2005, considerando o primeiro e o segundo ciclo de produção está representado na Figura 8. O ciclo da cultura foi dividido em 7 estádios de desenvolvimento, adaptando às curvas de $K c$ obtidas, de acordo com os estádios proposto por Maciel et al., (1994), como segue:

Estádio I - Crescimento vegetativo inicial ou fase juvenil (viveiro);

Estádio II - Crescimento vegetativo apical;

Estádio III - Crescimento vegetativo lateral;

Estádio IV - Floração e frutificação; 
Estádio V - Maturação dos frutos;

Estádio VI - Pós-maturação dos frutos;

Estádio VII - Renovação de ramos.

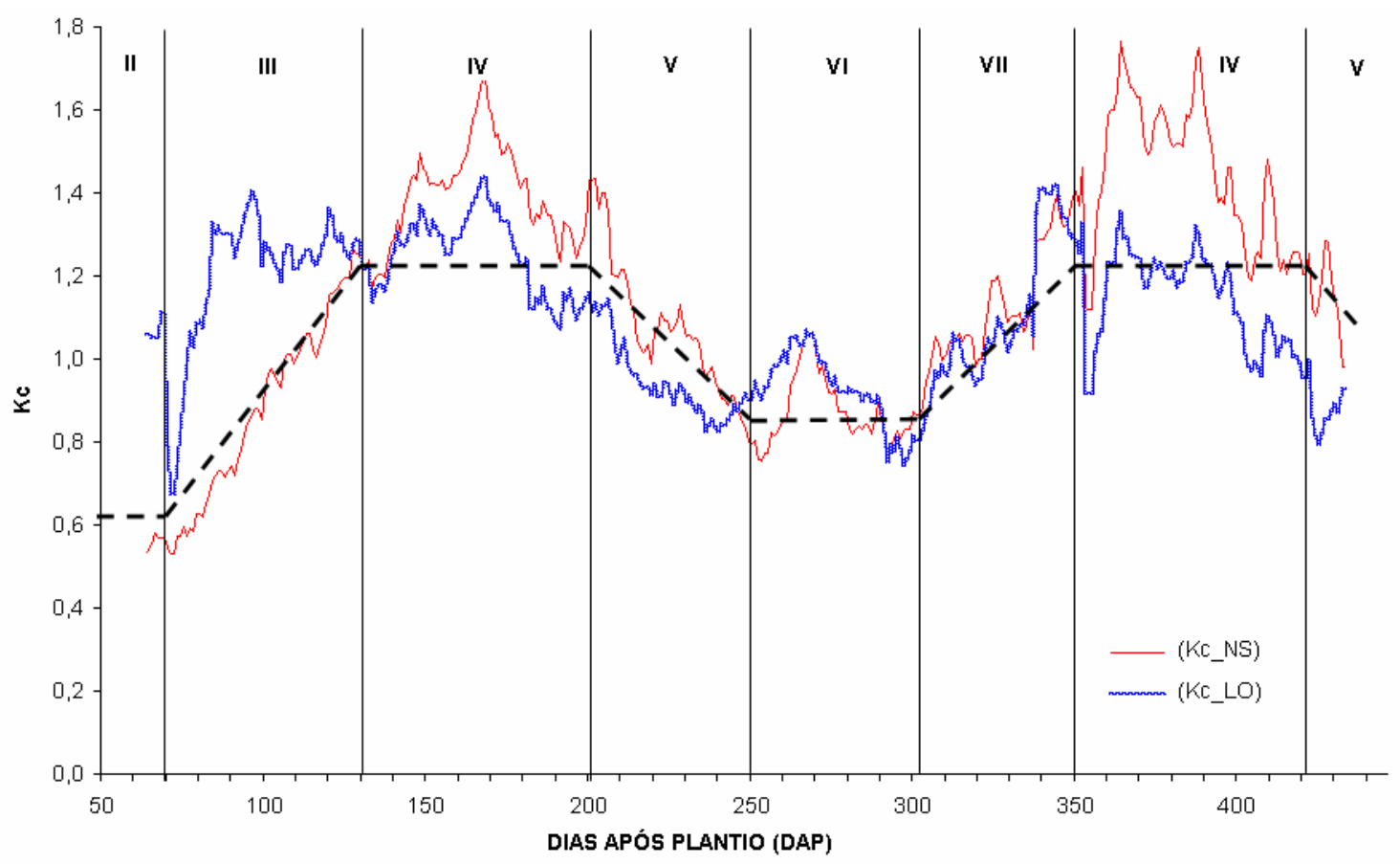

Figura 8 - Coeficientes de cultivo nos diferentes estádios (II, III, IV, V, VI e VII), determinados por lisímetros de pesagem hidráulica $(L P H)$ em maracujazeiros com diferentes direções de linha de plantio, Norte-Sul (NS) e Leste-Oeste $(L O)$

O estádio I refere-se ao crescimento vegetativo inicial de plantas em fase de formação das mudas, sendo estas cultivadas em ambiente controlado, e por essa razão não foi representado na figura 8. Esta fase ocorreu antes da implantação da cultura, e durou aproximadamente 80 dias após a germinação. O crescimento vegetativo apical caracterizou o estádio II de desenvolvimento. Este estádio durou cerca de 70 dias, porém verificou-se desuniformidade no crescimento no stand em campo. Vale ressaltar que para as plantas dos lisímetros foram selecionadas mudas de mesmo padrão de desenvolvimento. Em média, a ETc acumulada nesta fase foi de 36,71 mm (Tabela 2) com Kc igual a 0,62.

No estádio III, as plantas apresentaram uma taxa de crescimento acentuado, ocorrendo uniformização do stand. Esta fase apresentou uma curta duração, cerca de 30 
dias e $K c$ médio para as duas parcelas de 0,92. O período de florescimento coincidiu com os maiores valores de ETC registrado de 4,69 e 4,17 mm, para as plantas das parcelas $N S$ e $L O$, respectivamente, ocorridos nos meses de fevereiro, março e abril. Dessa forma, o valor de Kc foi maior $(1,22)$, definindo o IV estádio fenológico que teve duração de 68 dias.

No V estádio, predominou o amadurecimento dos frutos originados das flores fecundadas na fase anterior. Neste estádio a ETc acumulada foi $543 \mathrm{~mm}$ e Kc próximo de 1,00. O período de menor disponibilidade energética favoreceu a mudança do V para o VI estádio, ou seja, fase de pós-maturação dos frutos. Sua duração foi de aproximadamente 52 dias, ocorridos na estação de inverno, e diminuindo o valor de Kc para 0,82. Este período proporcionou os menores valores de consumo, em média, com ETc de 2,45 e 2,54 mm planta $^{-1}$. Maciel et al., (1994) definiram o estádio VI de 'repouso vegetativo', porém, o valor de $K c$ para a fase posterior ao estádio $\mathrm{V}$, obtido neste trabalho, 0,82, indicou que as plantas transpiravam em taxas elevadas, não sendo adequado, neste caso, utilizar a definição 'repouso vegetativo'. Dessa maneira, definiu-se o estádio VI de 'pós-maturação dos frutos'.

Com o aumento do fotoperíodo e disponibilidade de radiação, iniciou o VII estádio com surgimento de brotações de novos ramos a partir das gemas axilares das flores produzidas no III estádio. O VII estádio foi caracterizado pela renovação dos ramos com crescimento semelhante ao III estádio do ciclo anterior. Houve incremento do Kc com valor médio igual a 1,00. Identificou-se o último estádio como sendo uma repetição do IV estádio aplicado ao $2^{\circ}$ ciclo de produção. A ETc média acumulada no final desse estádio foi de 1060,84 mm, reproduzindo-se o mesmo valor de Kc obtido no IV estádio $(1,22)$. A Tabela 2 apresenta os estádios fenológicos com seus respectivos intervalos temporais, ETc e valores médios de $K c$. 
Tabela 2. Valores médios de $K c$ e de ETc obtidos nos quatro lisímetros de pesagem hidráulica instalados no cultivo de maracujazeiros.

\begin{tabular}{cccc}
\hline $\begin{array}{c}\text { Período } \\
\text { DAP }\end{array}$ & Estádio Fenológico & $\begin{array}{c}\text { ETc acumulada } \\
(\mathrm{mm})\end{array}$ & Kc \\
\hline Viveiro (75 dias) & I & - & - \\
$0-70 \quad(70)$ & II & 36,71 & 0,62 \\
$71-131 \quad(60)$ & III & 216,80 & 0,92 \\
$132-200(68)$ & IV & 465,08 & 1,22 \\
$201-250(49)$ & V & 543,36 & 1,00 \\
$251-303(52)$ & VI & 645,88 & 0,82 \\
$304-350(46)$ & VII & 781,01 & 1,00 \\
$351-422(71)$ & IV & 1060,84 & 1,22 \\
\hline
\end{tabular}

Valores entre parênteses da primeira coluna da tabela corresponde aos dias de duração de cada estádio.

\subsection{Conclusões}

Os maracujazeiros apresentaram os menores valores de consumo, em média $5 \mathrm{~L}$ planta $^{-1}$ dia $^{-1}$, durante o Outono e Inverno, e os maiores valores de $8 \mathrm{~L} \mathrm{planta}^{-1} \mathrm{dia}^{-1}$, no Verão.

Não houve diferença significativa entre as evapotranspirações das parcelas durante os meses de menor disponibilidade energética. A rugosidade da superfície promovida pelas linhas da parcela Leste-Oeste, interagiram mais com a atmosfera, aumentando a evapotranspiração, que tornou os valores semelhantes aos da parcela Norte-Sul, nos meses de menor disponibilidade energética.

A lâmina acumulada até o 450 dias após o plantio foi de $1171 \mathrm{~mm}$ para a parcela Norte-Sul, e 1083 mm para a parcela Leste-Oeste.

Foram determinados 6 estádios de desenvolvimento, com valores de Kc de 0,6 para a fase de crescimento vegetativo apical, 0,9 para a fase de crescimento vegetativo lateral, 1,2 para a fase de floração e frutificação, 1 para a fase de maturação dos frutos, 0,8 para a fase pós-maturação dos frutos e 1 para a fase de renovação de ramos no segundo ciclo de produção. 


\section{CONCLUSÕES GERAIS}

A utilização do modelo de análise e exclusão de intervalos em que o método de Razão de Bowen falha, melhora a qualidade dos dados. Aproximadamente $48 \%$ dos intervalos amostrados apresentaram algum tipo de erro, e desses, mais de $90 \%$ dos casos acontecem durante o período da noite.

O polimorfismo foliar apresentado pelo maracujazeiro não interfere nas determinações de áreas foliares por meio da variável comprimento da folha. A área foliar do maracujazeiro pode ser estimada em função da idade da planta e graus-dia acumulados.

O arranjo das células de carga hidráulica em forma de triangulo eqüilátero e o estabelecimento do volume ideal de fluído proporciona calibrações lineares, distribuição equilibrada de forças, e consequentemente, boa estabilidade e precisão nas determinações de evapotranspiração.

Não houve diferença significativa entre as evapotranspirações das parcelas durante os meses de menor disponibilidade energética. A rugosidade da superfície promovida pelas linhas da parcela Leste-Oeste, interagiram mais com a atmosfera, aumentando a evapotranspiração que tornou os valores semelhantes aos da parcela Norte-Sul, nos meses de menor disponibilidade energética.

Foram identificados 6 estádios de desenvolvimento, com valores de $K c$ de 0,6 para a fase de crescimento vegetativo apical, 0,9 para a fase de crescimento vegetativo lateral, 1,2 para a fase de floração e frutificação, 1 para a fase de maturação dos frutos, 0,8 para a fase pós-maturação dos frutos e 1 para a fase de renovação de ramos. 


\section{REFERÊNCIAS BIBLIOGRÁFICAS}

ABOUKHAlED, A.; ALFARO, A.; SMITH, M. Lysimeters. Roma: FAO, 1982. 68p. (Irrigation and Drainage Paper, 39).

AGUIAR, D.R.D.; SANTOS, C.C.F. Importância econômica e mercado. In: BRUCKNER, C. H.; PIÇANHA, M. C. (Ed.). Maracujá: tecnologia de produção, pós-colheita, agroindústria, mercado. Porto Alegre: Cinco Continentes, 2001. p.9-32.

ALENCAR, C.M. Consumo de água do maracujazeiro amarelo (Pasiflora edulis Sins var flavicarpa Deg). Piracicaba, 2000. 49p. Dissertação (Mestrado)- Escola Superior de Agricultura “Luiz de Queiroz”, Universidade de São Paulo.

ALLEN, R. G.; PEREIRA, L. S.; RAES, D.; SMITH, M. Guidelines for computing crop water requerements. Rome: FAO, 1998. 310p. (Irrigation and Drainage Paper, 56).

ANDRADE, J.M.B.; BRANDÃO FILHO, J.E.T.; VASCONCELOS, M.A.S. Efeito da densidade de plantio no primeiro ano de produção do maracujazeiro amarelo, no noroeste do Paraná. Revista Brasileira de Fruticultura, v. 16, n. 2, p. 49-54, set. 1994.

ANDREAS, E.L. Comments on physical bound on the Bowen ratio. Journal of Applied Meteorology, n.28, p.1252-1254, 1989.

ANDREAS, E.L.; CASH, B.A. A new formulation for the Bowen ratio over saturated surfaces. Journal of Applied Meteorology, n.35, p.1279-1289,1996. 
ANGUS, D.E.; WATTS, P.J. Evapotranspiration - how good is the Bowen ratio method.

Agricultural Water Management, n.8, p.133-150, 1984.

ASHKTORAB, H.; PRUITT, W.O.; PAW, K.T.; GEORGE, W.V. Energy balance determinations close to the soil surface using a micro-Bowen ratio system. Agricultural and Forest Meteorology, n.46, p.259-274, 1989.

AZEVEDO, P. V.; TEIXEIRA, A.H.C.; SILVA, B.B.; SORES, J.M.; SARAIVA, F.A.M. Avaliação da reflecatância e do saldo de radiação sobre um cultivo de videira européia. Revista Brasileira de Agrometeorologia, v.5, n.1, p.1-7, 1997.

BERTELA, M. Inconsistent surface flux partitioning by the Bowen ratio method. Boundary-Layer Meteorology, n.49, p.149-167, 1989.

BERNAT, C.; OUCIER, R.; SABOURIN, E. A cisterna de placas: técnica de construção. 2.ed. Recife: SUDENE/DPP: FUNDAJ, Ed. Massangana, 1993. 74p.

BLAD, B.L.; ROSENBERG, N.J. Lysimetric calibration of the Bowen ratio-energy balance method for evapotranspiration estimation in the Central Great Plains. Journal of Applied Meteorology, n.13, p.227-236, 1974.

BOWEN, I.S. The ratio of heat losses by conduction and by evaporation from any water surface, Physical Review, v.27, p.779-787. 1926.

BRUCKNER, C.H.; PICANÇO, M.C. Tecnologia pós colheita, agroindústria e mercado. Porto Alegre: Cinco continentes, 2001. 472p.

BRUTSAERT, W. Evapotranspiration into the atmosphere: Theory, history and applications. Dordrecht: D. Reidel Publishing, 1982. 299p. 
CELLIER, P.; RICHARD, G.; ROBIN, P. Partition of sensible heat fluxes into bare soil and the atmosphere. Agricultural and Forest Meteorology, n.82, p.245-265, 1996.

CEREDA, E.; VASCONCELOS, M.A.S. Influência da densidade de plantio na produtividade do maracujazeiro amarelo (Passiflora edulis Sims. f. flavicarpa Deg.). Revista Brasileira de Fruticultura,v.13, n.1, p.131-135, 1991.

CORRÊA, R.A.L. Evapotranspiração e coeficiente de cultura em dois ciclos de produção do maracujazeiro amarelo. Piracicaba, 2004. 57p. Dissertação (Mestrado)- Escola Superior de Agricultura “Luiz de Queiroz”, Universidade de São Paulo.

COSTA, E.L.; SOUSA, V. F.; NOGUEIRA, L. C.; SATURNINO, H. M. Irrigação da cultura do maracujazeiro. Informe Agropecuário, v.21, n.206, p.59-66, 2000.

COSTA, M.S.V. Determinação da evapotranspiração de referência por evapotranspirômetro de pesagem hidráulica com arranjo de "pistão de mercúrio". Recife, 1999. 85p. Dissertação (Mestrado) - Universidade Federal Rural de Pernambuco.

CUNHA, A.R.; ESCOBEDO, J.F.; KLOSOWSKI, E.S. Estimativa do fluxo de calor latente pelo balanço de energia em cultivo protegido de pimentão. Pesquisa Agropecuária Brasileira, v.37, n.6, p.735-743, 2002.

DYLLA, A.S.; COX, L.M. An economical lysimeter for evapotranspiration studies. Agronomy Journal, v.57, p.634-636, 1973.

EMPRESA BRASILEIRA DE PESQUISA AGROPECUÁRIA. Centro Nacional de Pesquisa de Solos. Sistema Brasileiro de Classificação de Solos. Rio de Janeiro, 1999. 412p.

FNP CONSULTORIA \& COMÉRCIO. Agrianual 2000: anuário da agricultura brasileira. São Paulo, 2000. p.398: Maracujá. 
FNP CONSULTORIA \& COMÉRCIO. Agrianual 2002: anuário da agricultura brasileira. São Paulo, 2002. p.402-408: Maracujá.

FREITAS, J. A. G. Evapotranspirômetro de pesagem por sensor de carga hidráulica: construção, calibração e testes. Recife, 1994. 122p. Dissertação (Mestrado) Universidade Federal Rural de Pernambuco.

FRIZINA, V. A.; ESCOBEDO, J. F. Balanço de radiaçõa e energia da cultura de alface em estufa de polietileno. Pesquisa Agropecuária Brasileira, v.34, n.10, p.1775-1786, out. 1999.

FUCHS, M.; TANNER, C.B. Error analysis of Bowen ratios measured by differential psychrometry. Agricultural and Forest Meteorology, n.7, p.329-334, 1970.

HANKS, R.J.; SHAWCROFT. An economical hydraulic weighing evaporation tank. Transaction of the ASAE, v.16, n.2, p.294-295, 1965.

HEILMAN, JL., BRITTIN, C.L. Fetch requirements for Bowen ratio measurements of latent and sensible heat fluxes. Agricultural and Forest Meteorology, n.44, p.261273, 1989.

HORST, T.W.; WEILL, J.C. Footprint estimation for scalar flux measurements in the atmospheric surface layer. Boundary-Layer Meteorology, n.59, p.279-296, 1992.

INSTITUTO BRASILEIRO DE GEOGRAFIA E ESTATÍSTICA (Rio de Janeiro, RJ). Lavouras permanentes. www.ibge.gov.br (13 set. 2002).

JENSEN, M.E. Water consumption by agricultural plants. In: KOSLOWSKY T.T. Water deficits and plant growth. New York: Academic Pres, 1968. v.2. 
KELLER, J.; KARMELLI, D. Trickle irrigation desing parameters. Transaction of the ASAE. v.17, n.4, p.678-684, 1974.

KITS, H.; FELDENS, A.M.; MANICA, I.; FIORAVANÇO, J.C. Análise econômica de densidades de plantio do maracujá-amarelo no Município de Porto Lucena, RS. Pesquisa Agropecuária Brasileira, v. 31, n. 7, p.497-502, jul. 1996.

KUSTAS, W.P.; STANNARD, D.I.; ALLWINE, K.J. Variability in surface energy flux partitioning during Washita'92: resulting effects on Penman-Monteith and PriestleyTaylor parameters. Agricultural and Forest Meteorology, n.82, p.171-193, 1996.

LUCAS, A.A.T. Resposta do maracujazeiro amarelo (Passiflora edulis Sims. F. flavicarpa Deg) a lâminas de irrigação e doses de adubação potássica. Piracicaba, 2002. 88p. Dissertação (Mestrado) - Escola Superior de Agricultura "Luiz de Queiroz", Universidade de São Paulo.

MACIEL, N.; BATUTISTA, D.;AULAR, J. Crescimiento, desarrolo y arquitectura de Passiflora edulis f. flavicarpa. Proceeding Interamerican Society Tropical Horticultural, n.38, p.133-138, 1994.

MANICA, I.; RITZINGER, R.; MUNDSTOCK, E. C.; MARODIN, G. A. B.; KOLLER, O. C. Efeito de seis espaçamentos de plantio no $2^{\circ}$ ano de produção do maracujá amarelo (Passiflora edulis f. flavicarpa Deg.) em Guaíba/RS. Revista Brasileira de Fruticultura, v.11, n.1, p.25-30, abr. 1989.

MARIN, F.R.; ANGELOCCI, L.R.; COELHO FILHO, M.A. Construção e Avaliação de Psicrômetro Aspirado de Termopar. Scientia Agricola, v. 58, n. 4, p. 839-844, 2001.

McFARLAND, M.J.; WORTHINGTON, J. W.; NEWMAN, J. S. Design, installation and operation of a twin weighing lysimetre for fruits trees. Transactions of the ASAE, v.26, n.6, p.1717-1721, 1983. 
MELETTI, L.M.M.; SANTOS, R.R.; MINAMI, K. Melhoramento do maracujazeiroamarelo: obtenção do cultivar 'Composto IAC-27'. Scientia Agricola, v. 57, n. 3, p.491-498, jul./set. 2000.

MILLER, D.H. Water at the surface of the earth: an introduction to ecosystem hydrodynamics. International Geophysics Series, v.21. p.557, 1977.

MIRANDA M. C.; BEMELMANS P. F. Custo de produção e viabilidade econômica da cultura do maracujá amarelo (Passiflora edulis) no Estado de São Paulo. Agricultura em São Paulo, v.1, n.42, p.113-132, 1995.

MONTEITH, J.L.; UNSWORTH, M.H. Principles of environmental Physics, 2.ed. Edward Arnold, London: 1990. 291p.

OHMURA, A. Objective criteria for rejecting data for Bowen ratio flux calculations. Journal of Applied Meteorology, n.21, p.595-598, 1982.

OLIVER, H.R.; SENE, K.J. Energy water balances of developing viness. Agricultural and Forest Meteorology, v.61, p.167-185, 1992.

OMETTO, J.C. Bioclimatologia vegetal. São Paulo: Ceres, 1981. 440p.

ORTEGA-FARIAS, S.O.; CUENCA, R.H.; EK, M. Daytime variation of sensible heat flux estimated by the bulk aerodynamic meted over a grass canopy. Agricultural and Forest Meteorology, n.81, p.131-143, 1996.

PACE, C.A.M.; ARAÚJO, C.M. Efeito de densidade de plantio na cultura do maracujáamarelo (Passiflora edulis f. flavicarpa Deg.). In: CONGRESSO BRASILEIRO DE FRUTICULTURA, 6., Recife, 1981. Anais. Recife: SociedadeBrasileira de Fruticultura, 1981. p.972-982. 
PEREIRA, A.R.; ANGELOCCI, L.R.; SENTELHAS, P.C. Agrometeorologia: fundamentos e aplicações práticas. Guaíba: Agropecuária, 2002. 478p.

PEREIRA, A.R.; VILLA NOVA, N.A.; SENTELHAS, P.C. Evapo(transpi)ração. Piracicaba: FEALQ, 1997. 183p.

PEREZ P.J.; CASTELLVI, F.; IBAÑEZ M.; ROSELL J.I. Assessment of reliability of Bowen ratio method for partitioning fluxes. Agricultural and Forest Meteorology, v.97, p.141-150, 1999.

PEZZOPANE, J.R.M.; PEDRO JÚNIOR, M.J. Balanço de energia em vinhedo de 'Niagara Rosada'. Bragantia, v.62, n.1, 2003.

PHILIP, J.R. A physical bound on the Bowen ratio. Journal of Climate and Applied Meteorology, n,26, p.1043-1045, 1987.

PIRES, M.M.; SÃO JOSÉ, A.R. Custo de produção e rentabilidade da cultura do maracujazeiro. In: SÃO JOSÉ, . R. (Ed.). Maracujá: produção e mercado. Vitória da Conquista: UESB, 1994. p.223-233.

PIZA JÚNIOR, C.T. A cultura do maracujá na Região Sudeste do Brasil. In: SIMPÓSIO SOBRE A CULTURA DO MARACUJÁ. Jaboticabal, 1998. Anais. Jaboticabal: UNESPE, 1998. p.20-45.PEREIRA, A.R.; ANGELOCCI, L.R.; SENTELHAS, P.C. Agrometeorologia: fundamentos e aplicações práticas. Guaíba: Agropecuária, 2002. p.478.

RAMKHELAWAN, E.; BRATHWAITE, R.A.I. Leaf estimation by non-destructive methods in sour orange (Citrus aurantium L.). Tropical Agriculture. Trindad, v.67, n.3, July, 1990. 
RODRIGUES, J.J.V. Construção e testes preliminares de um evapotranspirômetro de célula de carga hidráulica: In: CONGRESSO BRASILEIRO DE CIÊNCIA DO SOLO, 21., Campinas, 1987. Anais. Campinas: Sociedade Brasileira de Ciência do Solo, 1987. p.68.

RUGGIERO, C.; SÃO JOSÉ, A.R.; VOLPE, C.A.; OLIVEIRA, J.C.; DURIGAN, J.F.; BUAMGARTNER, J.G.; SILVA, J.R., NAKAMURA, K.; FERREIRA, M.E.; KAVATI, R. PEREIRA, V.P. Maracujá para exportação: aspectos técnicos da produção. Brasília: EMBRAPA-SPI, 1996, 64p. (Publicações técnicas FRUPEX, 19)

SAAD, A.M.; FARIA, R.T.; FOLEGATTI, M.V.; PEREIRA, F.A.C. Comparação de métodos de estimativa dos coeficientes de cultura $(\mathrm{Kc})$ do feijoeiro. In: CONGRESSO BRASILEIRO DE ENGENHARIA AGRÍCOLA, 27., Poços de Caldas, 1998, Anais. Poços de Caldas: Sociedade Brasileira de Engenharia Agrícola, 1998. v.1, p.223-225.

SILANS A.P.; MONTENY B.A.; LHOMME J.P. The correction of soil heat flux measurements to derive an accurate surface energy balance by the Bowen ratio method. Journal of Hydrology, n.188-189, p.453-465, 1997.

SÃO JOSÉ, A.R. A cultura do maracujá nas Regiões Norte e Nordeste do Brasil. In: SIMPÓSIO BRASILEIRO SOBRE A CULTURA DO MARACUJAZEIRO, 5., Jaboticabal, 1998. Anais. Jaboticabal: Funep, 1998. p.3-17.

SENTELHAS, P.C.; PEREIRA A.R. A maior estiagem do século? Notícias Piracena, Piracicaba, v.6, n.50, p.1, 2000.

SILVA, A.A.G.; KLAR, E.A. Demanda hídrica do maracujazeiro amarelo (Passiflora edulis Sims f. flavicarpa Deg.). Revista Irriga. v.7, n.3, p.185-190, 2002. 
SILVA, F.C., Determinação da evapotranspiração utilizando o método do balanço de energia e lisímetro de pesagem. Piracicaba, 2000, 72p. Tese (Doutorado). Escola Superior de Agricultura “Luiz de Quiroz”, Universidade de São Paulo.

SILVA, F.C.; FOLEGATTI, M.V.; PEREIRA, A.R. e VILLA NOVA, N.A. Uso de dispositivos lisimétricos para medida da evapotranspiração de referência. Revista Brasileira de Agrometeorologia, v.7, n.1, p.19-23, 1999.

SILVA, T.J.A.; MONTENEGRO, A.A.; RODRIGUES, J.J.V.; BONFIM, E.M.S. Aplicação de lisímetro de pesagem hidráulica na determinação da evapotranspiração de referência, em Petrolina - PE. Engenharia Agrícola, v.23, n.3, p.511 - 520, 2003.

SINCLAIR, T.R.; ALLEN, L.H.; LEMON, E.R. An analysis of errors in the calculation of energy flux densities above vegetation by a Bowen ratio profile method. BoundaryLayer Meteorology, n.8, p.129-139, 1975.

SOUZA, V.F. Níveis de irrigação e doses de potássio aplicados via fertirrigação por gotejamento no maracujazeiro amarelo (Passiflora edulis Sims. F. flavicarpa Deg). Piracicaba, 2000. 178p. Tese (Doutorado) - Escola Superior de Agricultura "Luiz de Queiroz”, Universidade de São Paulo.

SOUZA, J.S.I.; MELETTI, L.M.M. Maracujá: Espécies, variedades, cultivo. Piracicaba: FEALQ, 1997. 179p.

TANNER, C.B. Measurements of evapotranspiration. In: Irrigation of Agricultural Lands. American Society of Agronomy, n.11, p.534-574, 1967.

TANNER, B.D.; GREENE, J.P.; BINGHAM, G.E. A Bowen-ratio design for long term measurements. St. Joseph, MI: American Society of Agricultural Engineers, 1987. p.1-6, (ASAE Paper, n.87-2503). 
TEIXEIRA, A.H.C. Influência do Rio São Francisco no microclima de suas margens. In: CONGRESSO BRASILEIRO DE AGROMETEOROLOGIA, 11., Florianópolis, 1999: Anais. Florianópolis. Sociedade Brasileira de Agrometeorologia, 1999, p.1605-1610.

TEIXEIRA, A.H.C. Avaliação dos componentes do balanço de energia durante o primeiro ano de cultura da banana. Revista Brasileira de Engenharia Agrícola e Ambiental, v.5, n.1, p.28-32, 2001.

TEIXEIRA, A.H.C.; AZEVEDO, P.V.; SILVA, B.B.; SOARES, J.M. Balanço de energia na cultura da videira, cv. "Itália". Revista Brasileira de Agrometeorologia, v.5, n.2, p.137-141, 1997.

TRAMBOUZE, W.; BERTUZZI, P.; VOLTZ, M. Comparision of methods for estimating actual evapotranspiration in a row-cropped vineyard. Agricultural and Forest Meteorology, v.91, p.193-208, 1998.

TURNER D.W.; MENZEL C.M.; SIMPSON D.R. Short term drying of half the root system reduces growth but not water status or photosynthesis in leaves of passionfruit ( Passifzora sp.). Scientia Horticulturae, v.65, p.25-36, 1996.

UNLAND, H.E.; HOUSER, P.R.; SHUTTLEWORTH, W.J.; YANG, Z.L. Surface fluxe measurement and modeling at a semi-arid Sonoran Desrt site. Agricultural and Forest Meteorology, n.82, p.119-153, 1996.

UTSUNOMIYA, N. Effect of temperature on shoot growth, flowering and fruit growth of purple passion fruit (Passiflora edulis Sims var. edulis). Scientia Horticulturea, v.52, n.1/2, p.63-68, 1992.

VAN GENUCHTEN, M.T.H. A closed form equation for predicting the hydraulic conductivity of unsaturated soils. Soil Science Society American Journal, n.44, p.892-898, 1980. 
RAIJ, B.Van.; CANTARELLA, H.; QUAGGIO, J.A.; FURLANI, A.M.C. Recomendações de adubação e calagem para o Estado de São Paulo. Boletim técnico do Instituto Agronômico, Campinas, n.100, p.1-107, 1992. 
APÊNDICES 


\section{APÊNDICE 1}
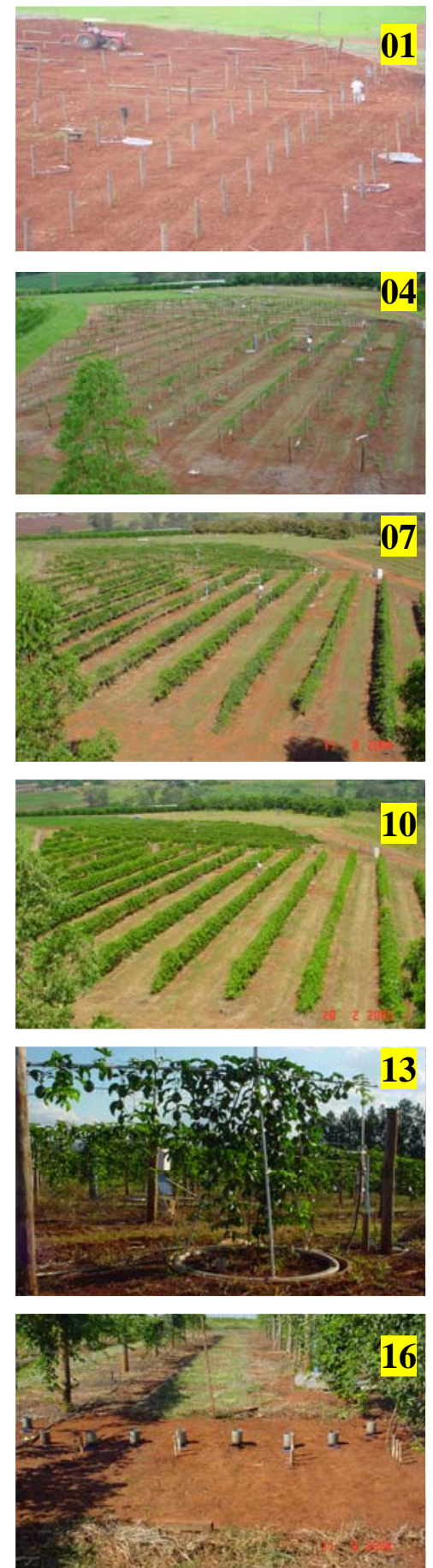
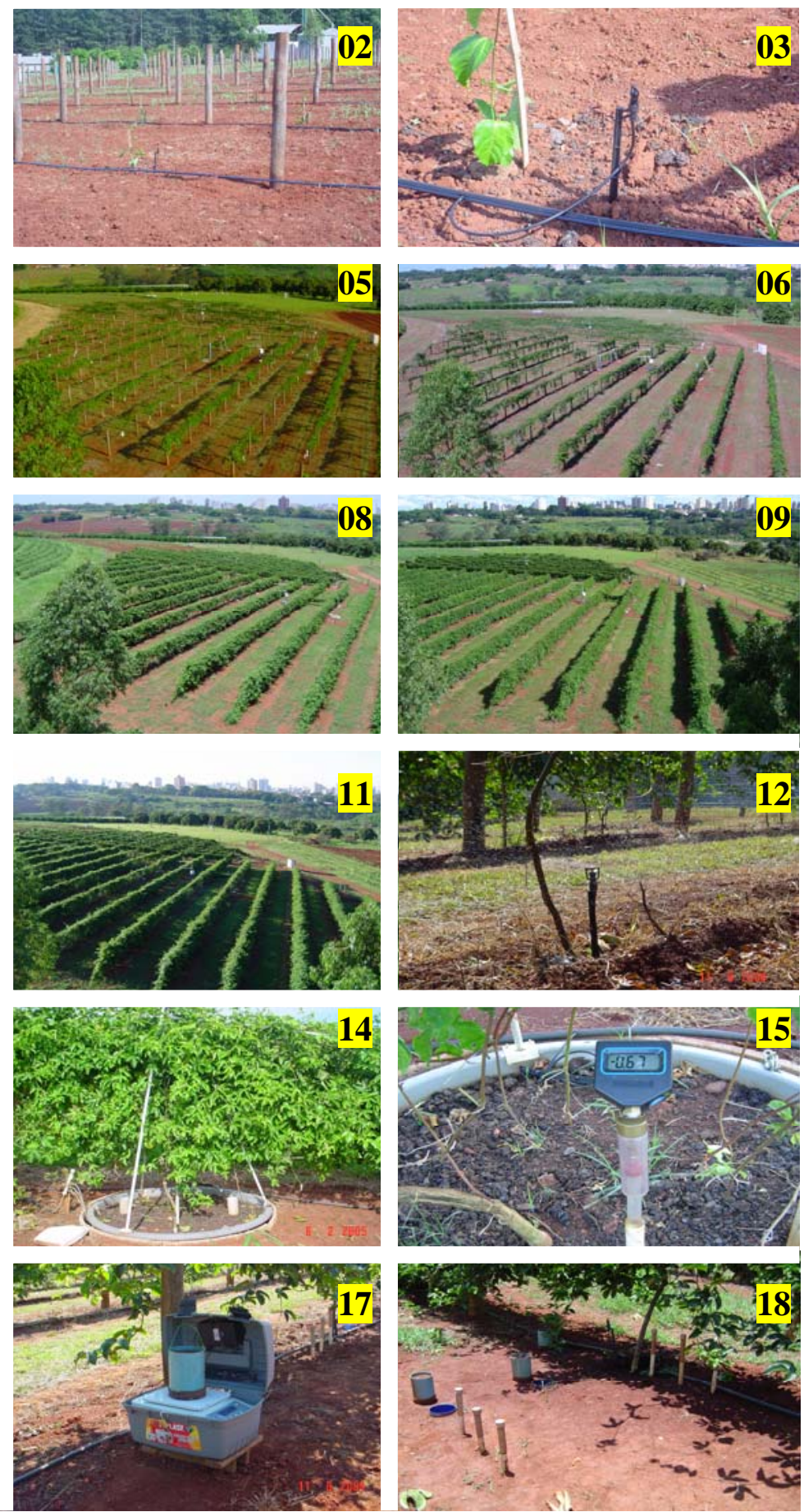

Etapas de instalação e condução do experimento: 01) Sistema de condução, 02) Sistema de irrigação, 03) Microaspersor, 04) a 11) Vista geral de 02/2004 a 02/2005, 12) Irrigação, 13) e 14) Sistema de condução do lisímetro, 15) Tensímetro, 16) Microlisímetros, 17) Balança para pesagem de microlisímetros e 18) Baterias de tensiômetros 
APÊNDICE 2
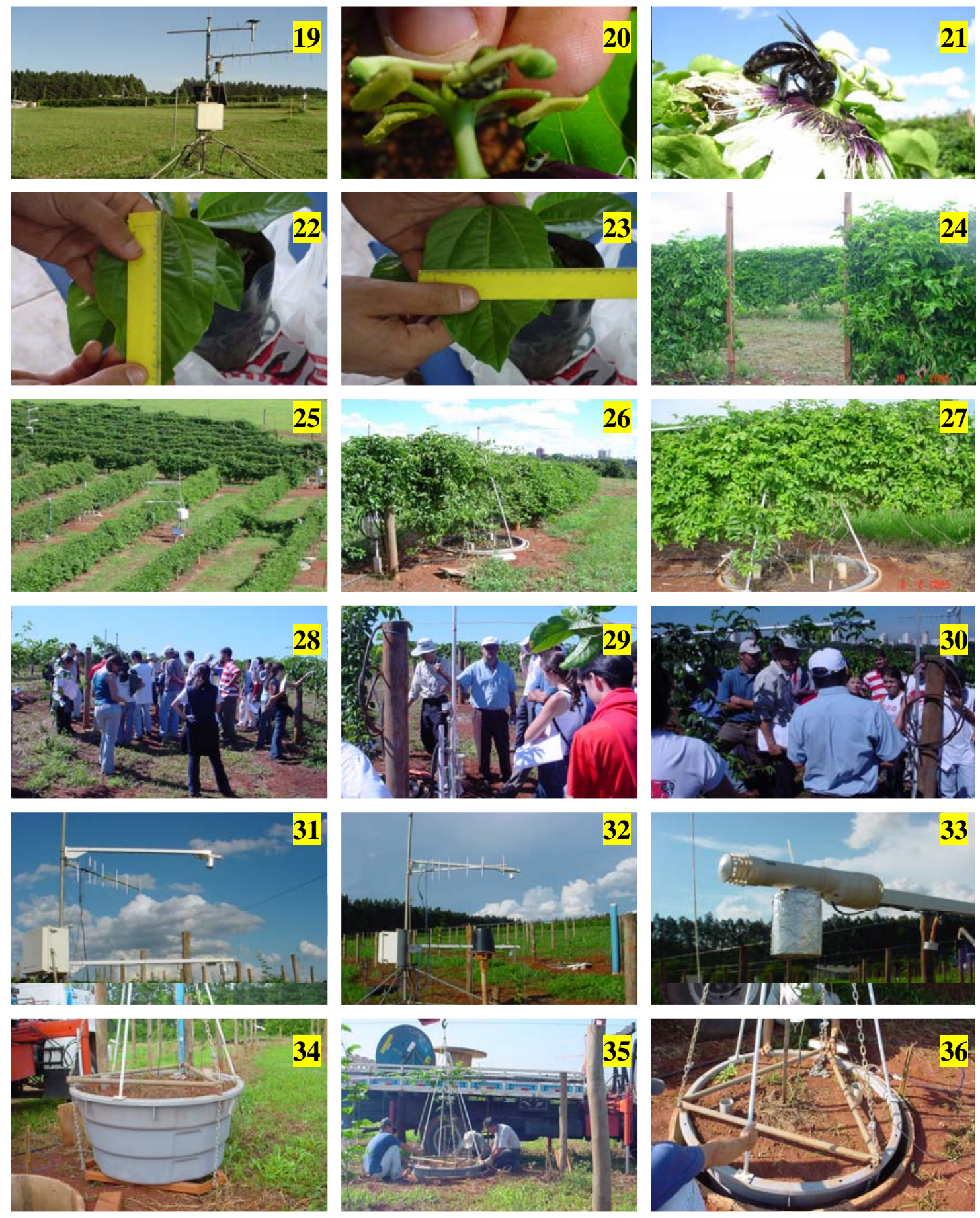

Etapas de instalação e condução do experimento: 19) Estação meteorológica, 20) e 21) Polinização artificial e natural, 22) a 24) Estimativa de área foliar, 25) Vista geral em 12/2004, 26) e 27) Sistema de condução do lisímetro, 28) a 30) Visita de alunos da disciplina de irrigação na área experimental, 31) a 33) Sistema de Razão de Bowen e 34) a 36) Manutenção dos lisímetros 